\title{
Bouwstenen Beweiding
}

Goed weiden verlaagt de productiekosten van melk en draagt bij aan het positieve imago van de melkveehouderij. Maar beweiden is wel een vak! Om dit vak beter uit te kunnen oefenen zet het Bouwstenenboek Beweiding nieuwe kennis uit Amazing Grazing op een rij.

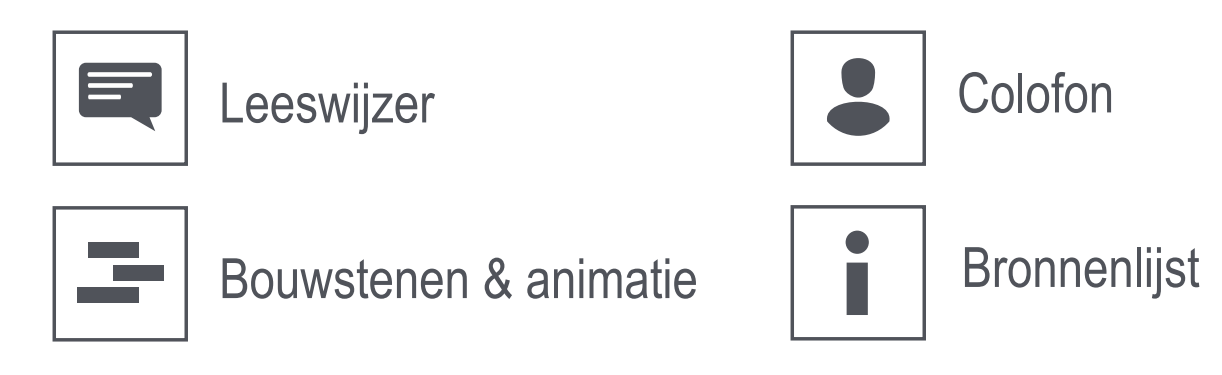

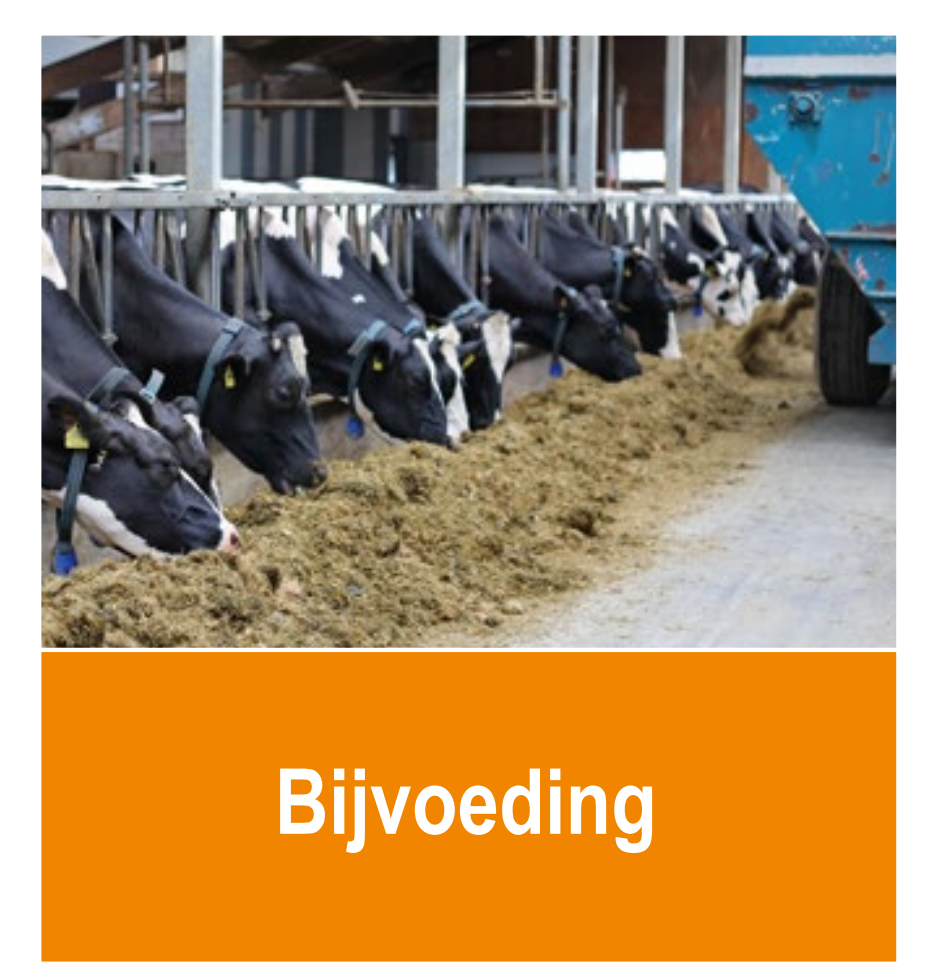
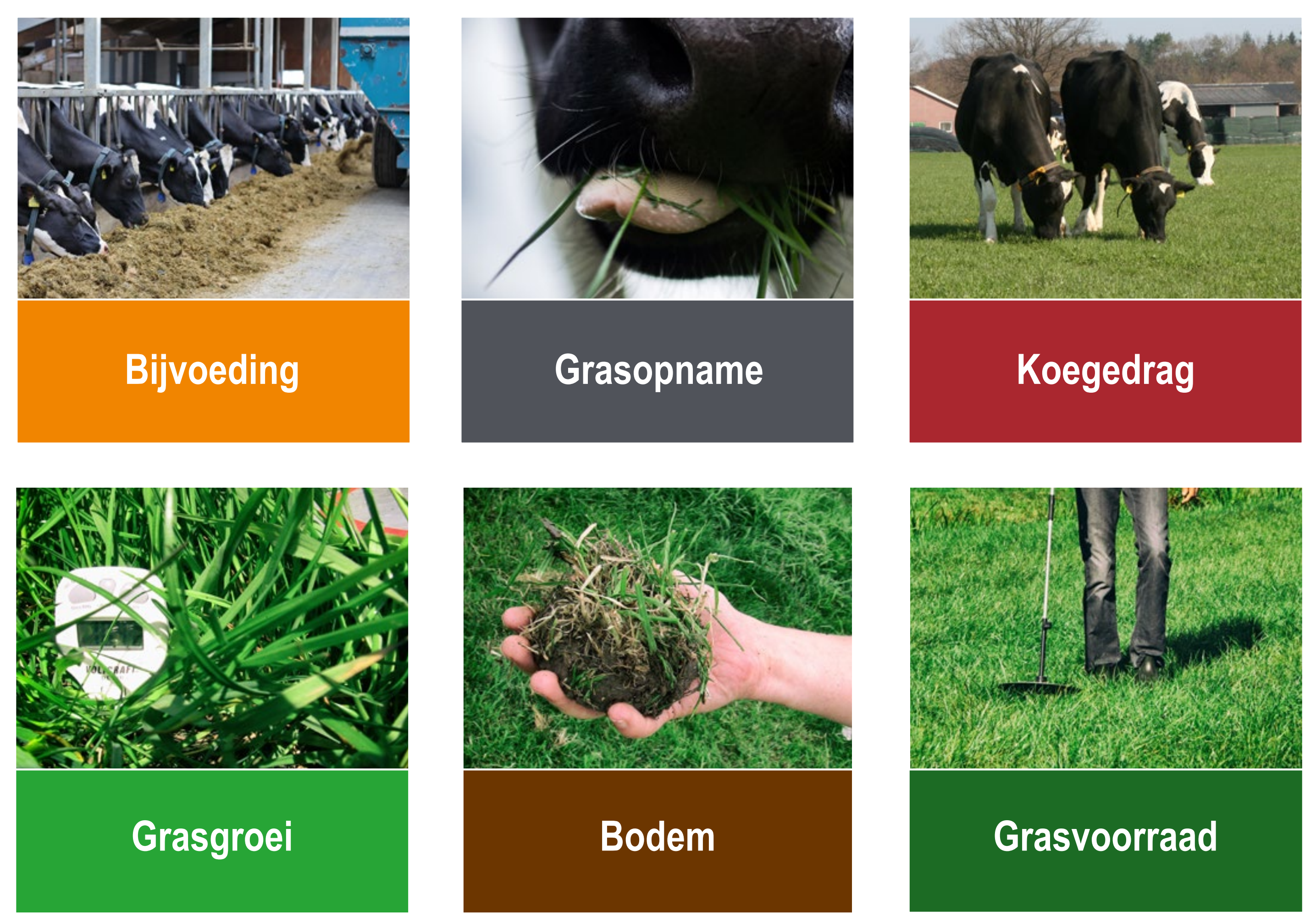

\section{Grasvoorraad}

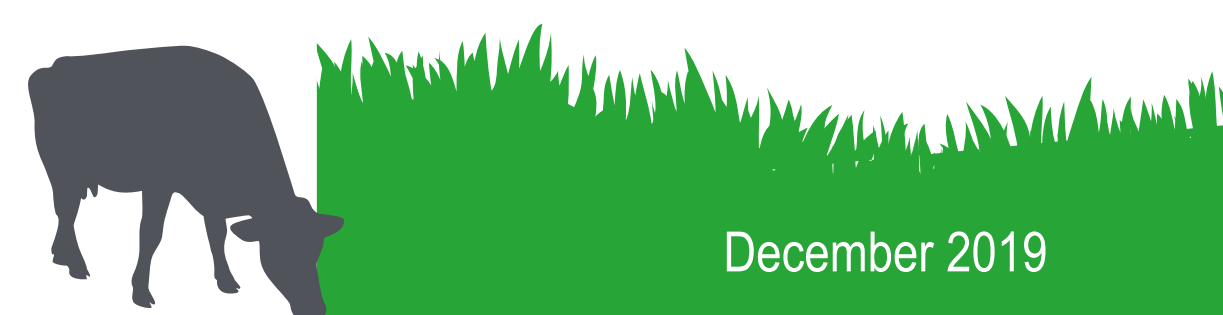




\section{Leeswijzer}

Beweiden is een wezenlijk onderdeel van toekomstgerichte melkveebedrijven. In Amazing Grazing hebben we oplossingen onderzocht en onderbouwd voor inpassing van beweiden op het bedrijf. Beweiden is geen kunst, maar een vak. Daarom staat het 'wat en hoe' van beweiden centraal.

Die oplossingen vertalen we naar kennis, managementtools en concrete beweidingssystemen voor de praktijk. Amazing Grazing stimuleert daarmee de toepassing en ontwikkeling van beweiden in Nederland, als onderdeel van modern vakmanschap.
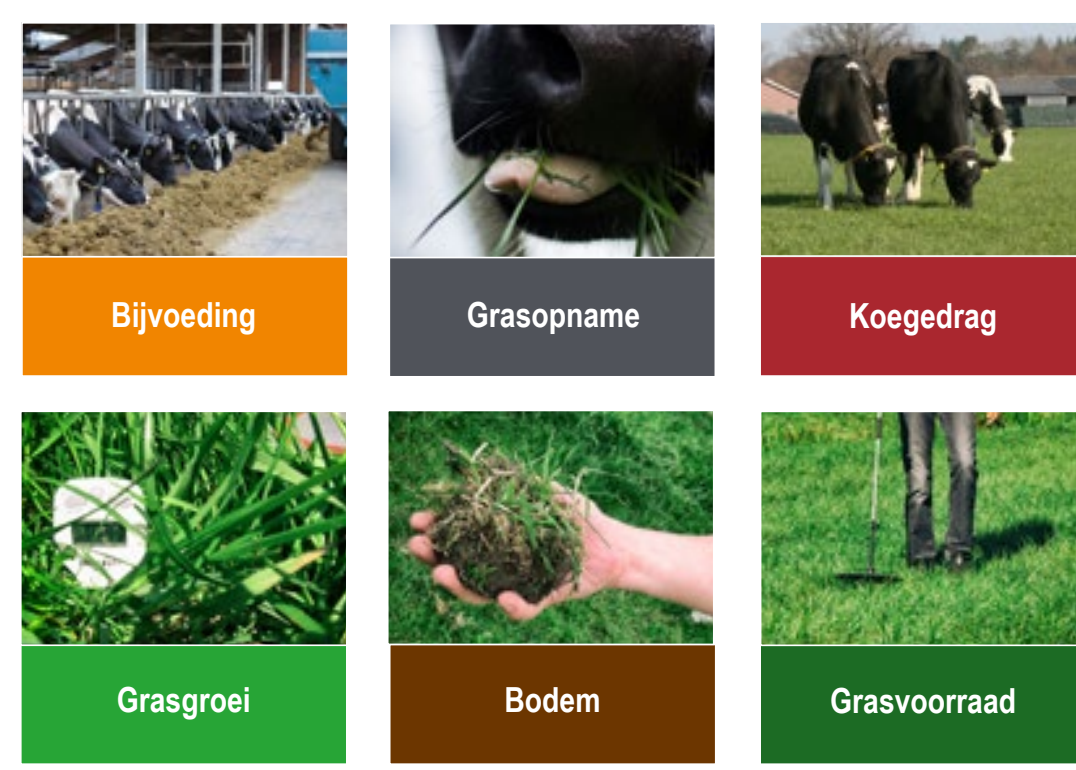

Bouwstenenboek beweiding

Het doel van Amazing Grazing is het ontwikkelen van de best mogelijke kennis voor beweiden en die toepasbaar maken voor de praktijk. Om die best mogelijke kennis wetenschappelijk te kunnen toetsen en te onderbouwen zijn tussen 2016 en 2018 veldproeven op de proefbedrijven Dairy Campus, KTC Zegveld en Vredepeel uitgevoerd. De resultaten zijn vertaald in zes kennisbouwstenen, die we in samenhang hebben bekeken.
De zes bouwstenen vormen de hoofdstukken van het Bouwstenenboek. Per bouwsteen zijn de belangrijkste processen beschreven, zoveel mogelijk ondersteund met resultaten uit het onderzoek in Amazing Grazing.

\section{Leeswijzer}

Per bouwsteen zijn de resultaten van het onderzoek verdeeld over paragrafen. In de rechterbalk van een pagina kun je rechtsboven navigeren naar de paragrafen binnen een bouwsteen, rechtsonder staan de knoppen om naar een andere bouwsteen of naar de startpagina / home van het e-book te klikken. Het boek bevat directe koppelingen naar de onderbouwende bouwsteenproducten waarin de definitieve complete resultaten zijn beschreven. Deze staan aan het eind van een paragraaf. Ben je nieuwsgierig naar nog meer kennis over beweiding, kijk dan in de Bronnenlijst.

$$
\text { Lees verder }
$$

Leeswijzer

- Bouwstenen \& animatie

8 Colofon

- Bronnenlijst

\begin{tabular}{|c|c|c|}
\hline \multicolumn{2}{|c|}{} \\
\hline Bijvoeding & Grasopname & Koegedrag \\
\hline \hline Grasgroei & Bodem & Grasvoorraad \\
\hline
\end{tabular}

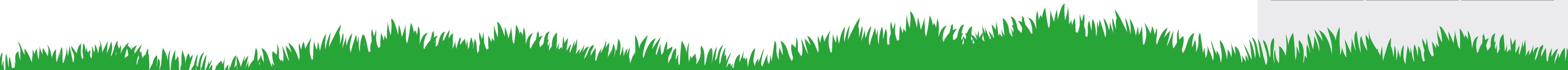




\section{Leeswijzer}

Let wel, een e-book is geen website. De navigatie werkt in een e-book net even anders doordat er geen back en forward-knoppen zijn. Het Bouwstenenboek in full-screen lezen verdient de voorkeur.

\section{Fundament is gelegd}

Met veel plezier hebben we gebouwd aan dit bouwstenenboek voor beweiding. Dit is voor nu het eindresultaat. Voor de toekomst zien we een belangrijke rol weggelegd voor gras binnen de melkveehouderij. Gras is hét sturingsmechanisme dat een belangrijke bijdrage kan leveren binnen de verschillende duurzaamheidsdoelen. Nu ligt de focus nog vooral op de koe. In toekomst is meer samenhang tussen bodem, productie, bedrijf en omgeving gewenst. Het fundament is met dit Bouwstenenboek gelegd, maar over gras is veel meer te ontdekken.

\section{Dankwoord}

We bedanken alle medewerkers op de proefbedrijven, de meedenkers van marktpartijen, zuivelsector en melkveehouders, en onderzoekers voor hun waardevolle werk en inbreng.

Namens het projectteam van Amazing Grazing,

Bert Philipsen en René Schils
C. Bouwstenen \& animatie

8 Colofon

- Bronnenlijst

\begin{tabular}{c|c||c|}
\hline Bijvoeding & Grasopname & Koegedrag \\
\hline \hline Grasgroei & Bodem & Grasvoorraad \\
\hline
\end{tabular}




\section{Bouwstenen beweiding}

De basis voor beweiding ligt in zes kennisbouwstenen die onderling samenhangen:

- Bouwsteen Grasopname

Een hoge benutting van weidegras

- Bouwsteen Grasvoorraad

Optimaal beheren van de grasvoorraad

- Bouwsteen Grasgroei

Voorspellen van de grasgroei in de

komende weken

\section{- Bouwsteen Bodem}

Zorgen voor optimale bodem voor groei en benutting van het weidegras

- Bouwsteen Bijvoeding

Optimaal bijvoeden in dienst van hoge

benutting weidegras

\section{- Bouwsteen Koegedrag}

Gebruiken van koegedrag voor een

hoge benutting van weidegras.

De animatie 'Haal meer uit je weidegras' is gemaakt om de bouwstenen en hun onderlinge samenhang uit te leggen.

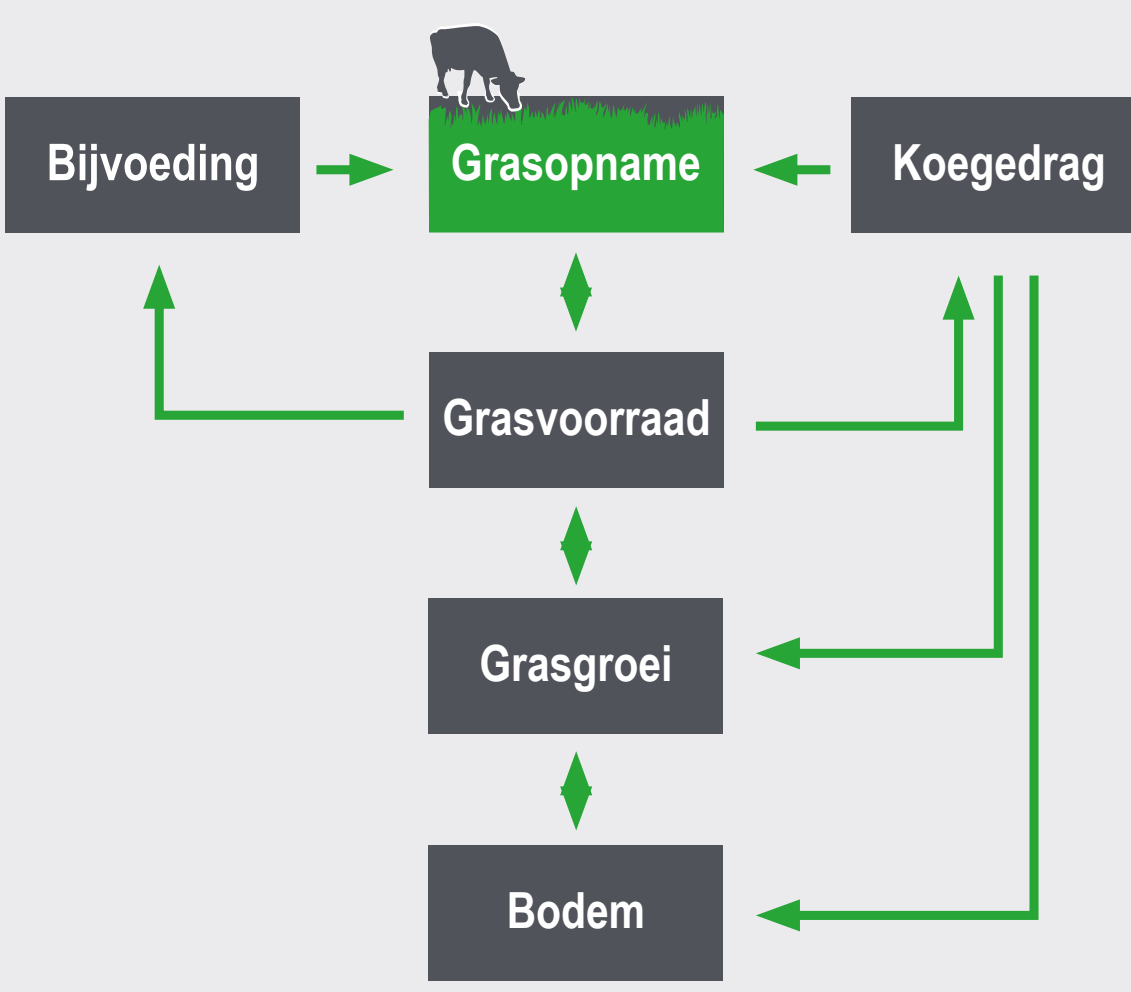

\section{Animatie}

\section{Haal meer uit je weidegras!}

Steeds meer melkveehouders willen meer uit beweiden en weidegras halen.

En terecht, want elke kilo gegraasd gras verlaagt de productiekosten van melk en draagt bij aan het positieve imago van de melkveehouderij, maar beweiden is wel een vak! Met kennis uit de bouwstenen voor weidegang kun je meer uit weidegras halen.

\section{Bronnenlijst}

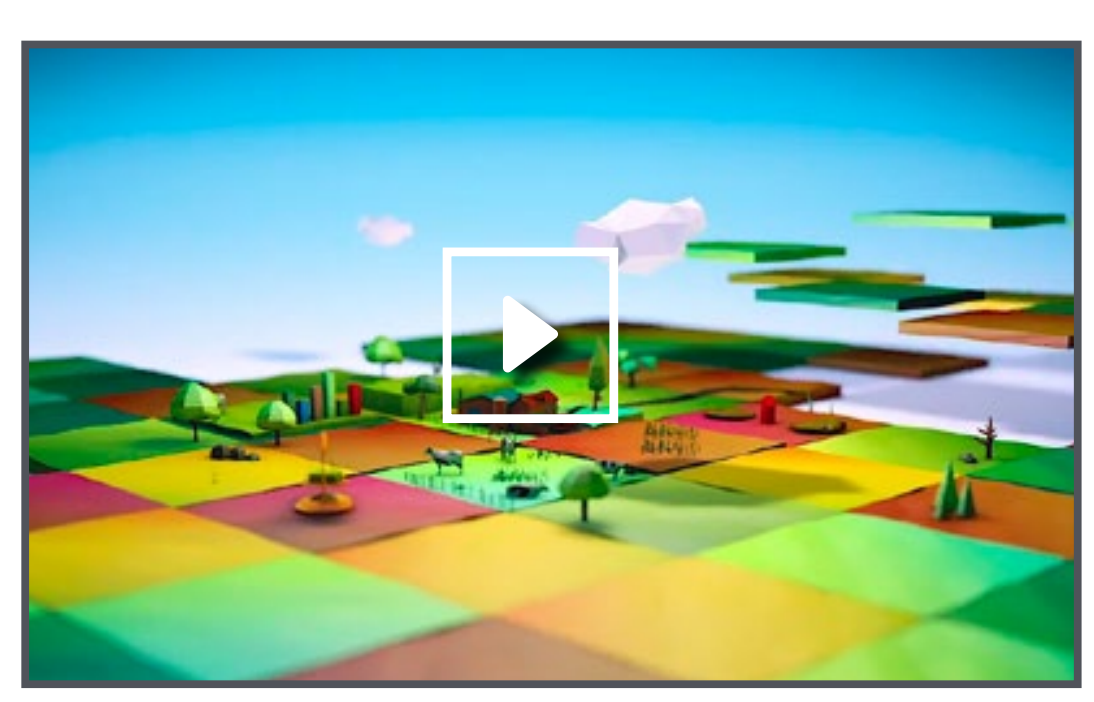

Bekijk animatie:

https://youtu.be/FQsBkXQXvzE

\begin{tabular}{|c|c|c|}
\hline \multicolumn{2}{|c|}{} \\
\hline \multicolumn{2}{|c|}{} \\
\hline Bijvoeding & Grasopname & Koegedrag \\
\hline \hline Grasgroei & Bodem & Grasvoorraad \\
\hline
\end{tabular}

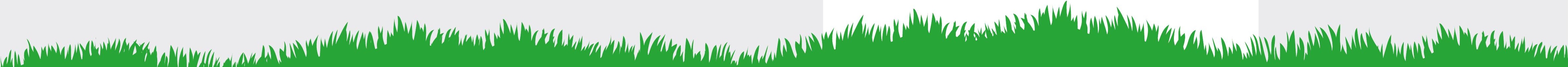




\section{Bijvoeding naast weidegras}

Maximaal weiden met hoge melkproductie vraagt om een uitgebalanceerd rantsoen. Met een uitgekiende bijvoeding blijft er genoeg ruimte voor de koe om veel vers gras te vreten.

\section{Melk uit gras}

Melkkoeien kunnen in de weide maximaal zo'n $17 \mathrm{~kg}$ droge stof per dag aan vers gras opnemen; goed voor ongeveer $22 \mathrm{~kg}$ melk per dag. Zo'n hoge grasopname in de wei vergt wel een lange weideduur (dag en nacht) bij een ruim grasaanbod, zo rond de $35 \mathrm{~kg}$ droge stof per koe per dag. Voor een maximale opname moet een koe kunnen selecteren. Daarbij moet je hoge weideresten voor lief nemen. Bovendien mag de kwaliteit en smakelijkheid van het gras niets te wensen overlaten. In het voorjaar lukt dat meestal wel, maar in de zomer en het najaar is dat lastiger.

\section{Opnamecapaciteit}

Op veel bedrijven is de huiskavel te klein

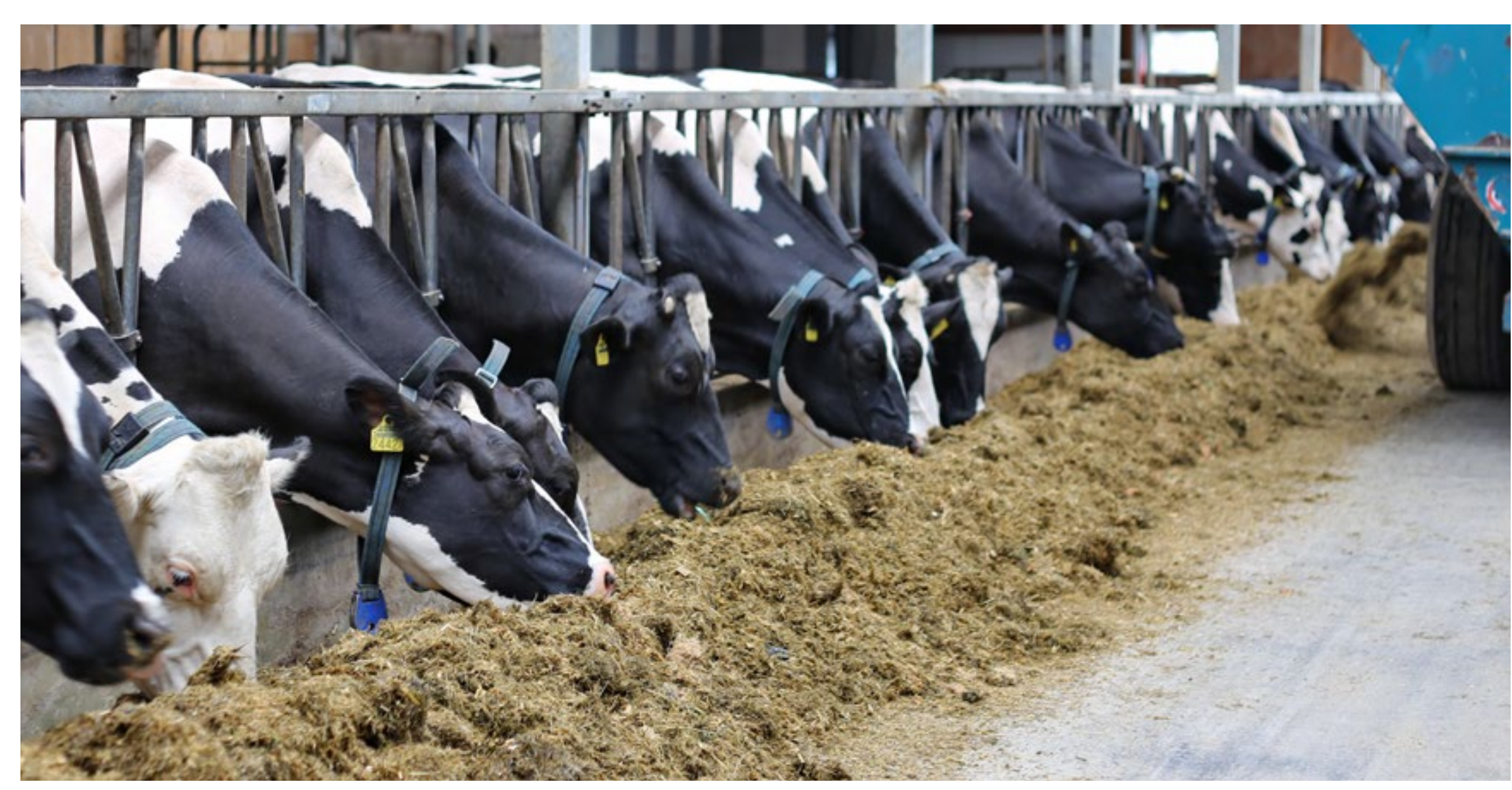

om het gehele groeiseizoen alleen weidegras aan te bieden. Bovendien is weidegras alleen meestal niet voldoende om te voldoen aan de energiebehoefte van hoogproductieve melkkoeien. De voeropnamecapaciteit van een koe is nu eenmaal begrensd. Om meer voerenergie in de koe te krijgen is het noodzakelijk om naast weidegras krachtvoer, snijmais of andere pro- ducten bij te voeren; liefst met lagere vulwaarde en hogere energie-inhoud. Bij voldoende vers gras is graskuil niet de beste optie, vanwege de hoge verdringing van weidegras en de lagere kwaliteit van de graskuil.

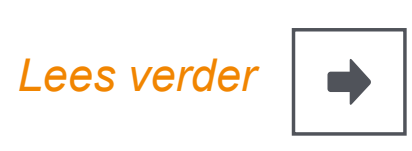

- Bijvoeding naast weidegras - Verdringing weidegras - Eiwit als graasmotivator

\begin{tabular}{|c|c|c|}
\cline { 2 - 3 } Bijvoeding & Grasopname & Koegedrag \\
\hline Grasgroei & Bodem & Grasvoorraad \\
\hline
\end{tabular}




\section{Hoge totale opname}

Bijvoeding van krachtvoer en snijmais leiden uiteraard tot een lagere grasopname, maar vanwege de lage verdringing neemt de totale opname toe. Snijmais en vers gras leggen een vrijwel gelijkwaardig beslag op de voeropnamecapaciteit van de koe; elke kilogram snijmais verdringt ongeveer 0,9 kilogram gras. De totale opname neemt daarmee iets toe. Het lage eiwitgehalte van snijmais sluit echter perfect aan bij het relatief eiwitrijke gras. De bijvoeding van krachtvoer verlaagt de opname van vers gras veel minder; elke kilogram krachtvoer verdringt ongeveer $0,4 \mathrm{~kg}$ vers gras.

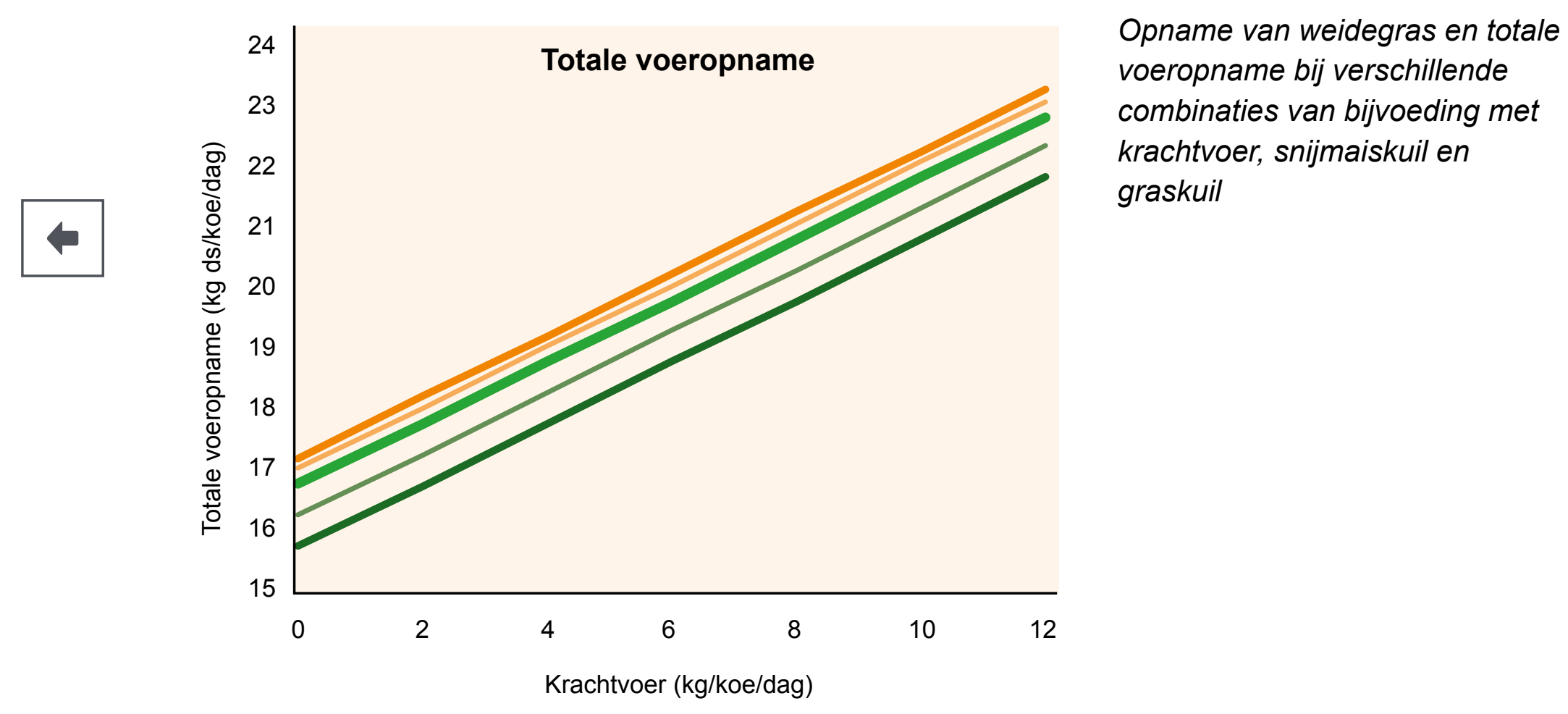

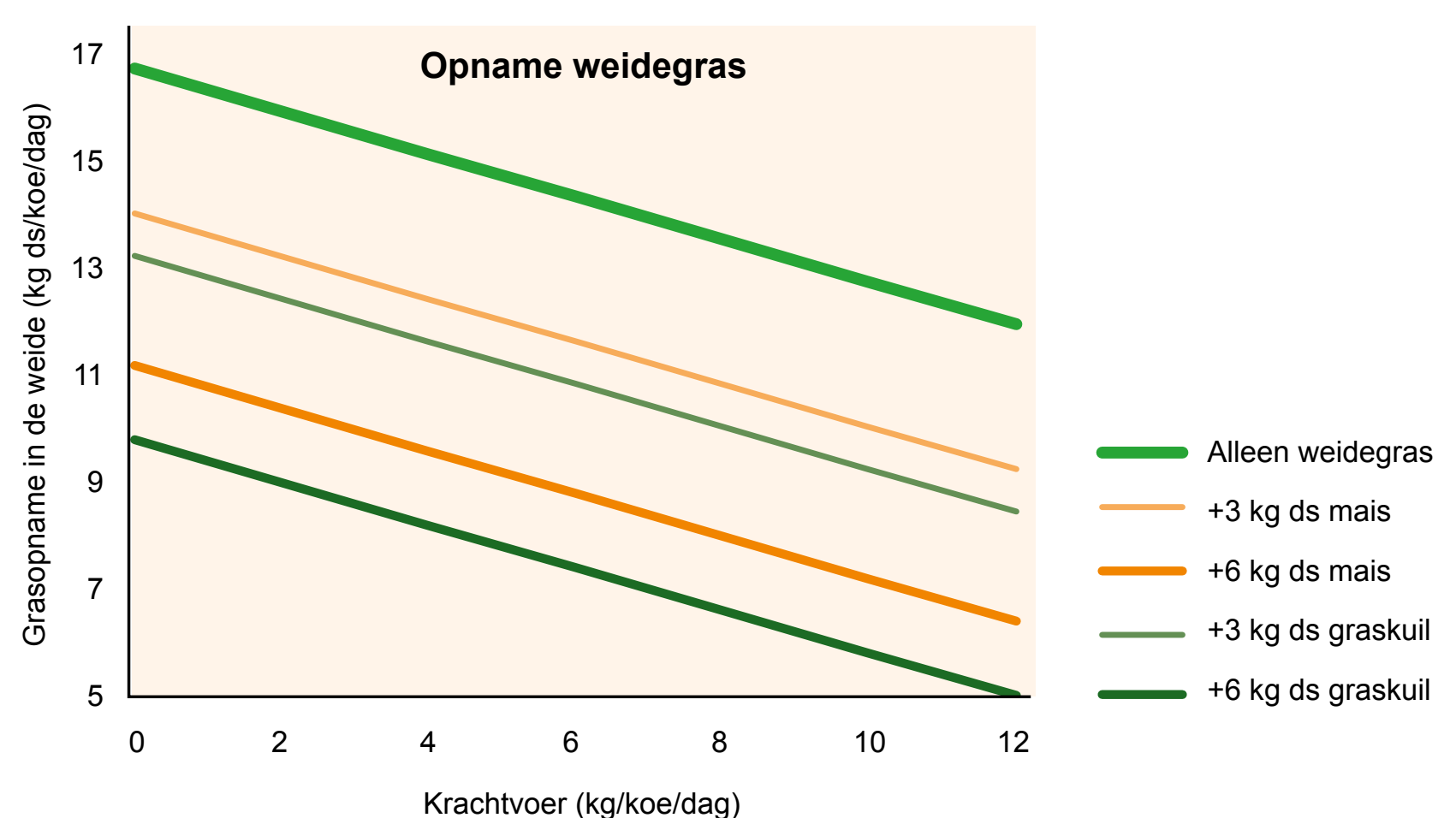

Bifvoeding

- Bijvoeding naast weidegras

- Verdringing weidegras

- Eiwit als graasmotivator

\begin{tabular}{|c|c|c|}
\hline Bijvoeding & Grasopname & Koegedrag \\
\hline Grasgroei & Bodem & Grasvoorraac \\
\hline
\end{tabular}




\section{Verdringing weidegras}

Bijvoeding met krachtvoer of ruwvoer verlaagt de opname van weidegras. De mate van verdringing is afhankelijk van de verzadigingswaarde van de bijvoeding én het eetbare grasaanbod.

\section{Grasopname zonder bijvoeding}

De maximale opname van weidegras, zonder enige bijvoeding, is afhankelijk van het grasaanbod in de weide. Bij een krap aanbod van rond de vijf tot tien $\mathrm{kg}$ ds per koe per dag, wordt het volledige aanbod opgevreten. Soms zelfs nog iets meer omdat de koeien in dat geval het gras korter dan vijf $\mathrm{cm}$ afgrazen. Ter illustratie: zo'n krap grasaanbod heb je bijvoorbeeld bij stripgrazen met een koppel van 100 koeien op een strip van 0,3 ha met een grashoogte van $14 \mathrm{~cm}$. Naarmate het grasaanbod toeneemt, neemt ook de maximale weidegrasopname verder toe. Bij een aanbod van $35 \mathrm{~kg}$ ds per koe per dag nemen de koeien bijna de helft van het aanbod op, zo'n $17 \mathrm{~kg}$ ds per koe per dag. Zo'n aan- bod heb je bijvoorbeeld bij tweedaags omweiden, waarbij een koppel van 100 koeien bij een grashoogte van $14 \mathrm{~cm}$ wordt ingeschaard op een perceel van bijna 5 ha. Om de laatste kilogram gras erin te krijgen moet het aanbod nog flink omhoog, maar dan wordt het beweidingsrendement lager dan $50 \%$.

\section{Opnamecapaciteit}

De voeropnamecapaciteit van een koe is begrensd. Deze is onder andere afhankelijk van het ras, de leeftijd, lactatiestadium en stadium van de dracht. Hoeveel voer een koe kan opnemen is afhankelijk van de voeropnamecapaciteit, maar ook van het soort voer. Elk voer heeft zijn eigen verzadigingswaarde die bepaalt hoeveel een koe kan opnemen. De gemiddelde verzadigingswaarden van weidegras, snijmais, graskuil en krachtvoer zijn respectievelijk 0,93 - 0,83-1,01 en 0,35.

\section{Verdringing in relatie tot voersoort}

De onderlinge verhoudingen tussen de

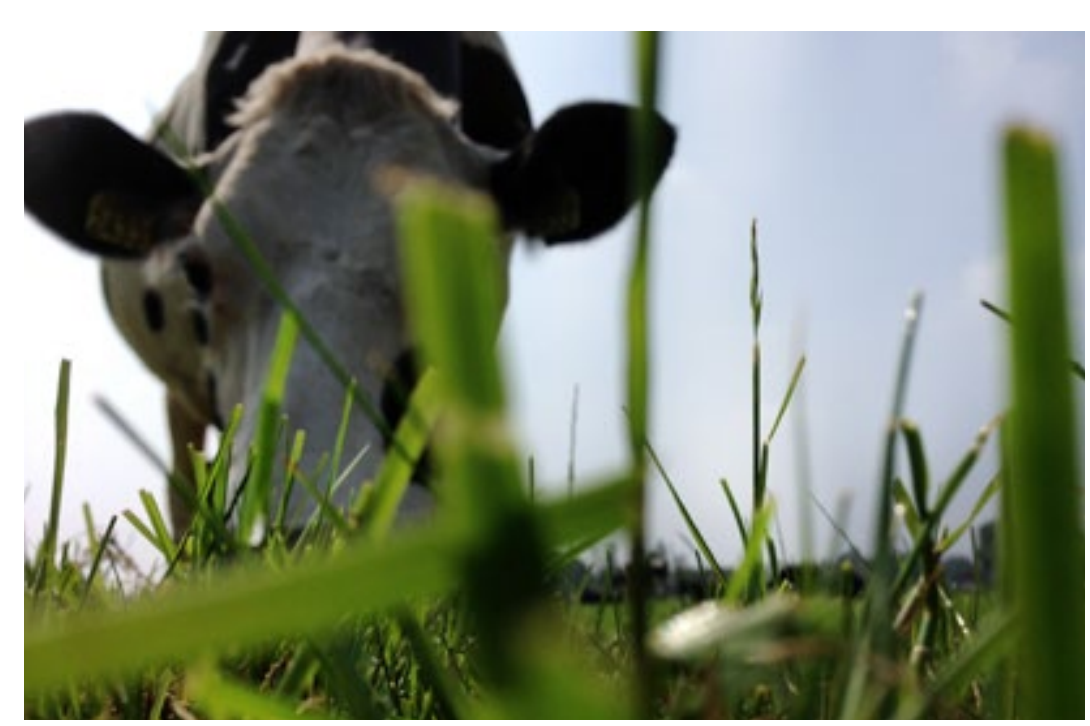

verzadingswaarde bepaalt de onderlinge verdringingswaarde van de voersoorten. De verdringingswaarden van weidegras door snijmais, graskuil en krachtvoer zijn gemiddeld dus $0,9(=0,83 / 0,93), 1,1$ en 0,4 . Dat betekent dat het bijvoeren van één $\mathrm{kg}$ ds snijmais, de weidegrasopname verlaagt met $0,9 \mathrm{~kg}$ ds.

\section{Verdringing in relatie tot grasaanbod}

De gemiddelde verdringingswaarden gel-

den bij een ruim grasaanbod van meer dan $50 \mathrm{~kg}$ ds per koe per dag. Bij een

$$
\text { Lees verder }
$$

Bijvoeding

- Bijvoeding naast weidegras - Verdringing weidegras

- Eiwit als graasmotivator 
onbeperkt grasaanbod wordt de volledige voeropnamecapaciteit van de koe benut. In dat geval zal elke kg bijvoeding resulteren in verdringing. In de meeste Nederlandse beweidingssystemen ligt het grasaanbod per koe echter lager. Bij een laag grasaanbod kan de koe haar voeropnamecapaciteit niet volledig benutten. Dit komt doordat de koe steeds meer moeite moet doen om gras op te nemen naarmate meer gras is opgenomen. Ook staat er minder gras naarmate de dag vordert, dat bovendien steeds verder vervuild raakt door mest en urine. Op dat moment ontstaat ruimte voor bijvoeding zonder dat dit tot grote verdringing leidt. Bijvoorbeeld bij een grasaanbod van $15 \mathrm{~kg}$ ds per koe verdringt $1 \mathrm{~kg}$ krachtvoer slechts $0,18 \mathrm{~kg}$ ds gras. Eén $\mathrm{kg}$ ds snijmais verdringt dan maar 0,4 $\mathrm{kg}$ ds gras. Dat betekent dat de weidegrasopname met bijvoeding van bijvoorbeeld 5 $\mathrm{kg}$ ds krachtvoer en $6 \mathrm{~kg}$ ds snijmais daalt van 12,5 naar $9,2 \mathrm{~kg}$ ds per koe per dag.

De verdringing is namelijk $(5 \times 0,18)+(6 x$ $0,4)=3,3 \mathrm{~kg}$ ds weidegras.

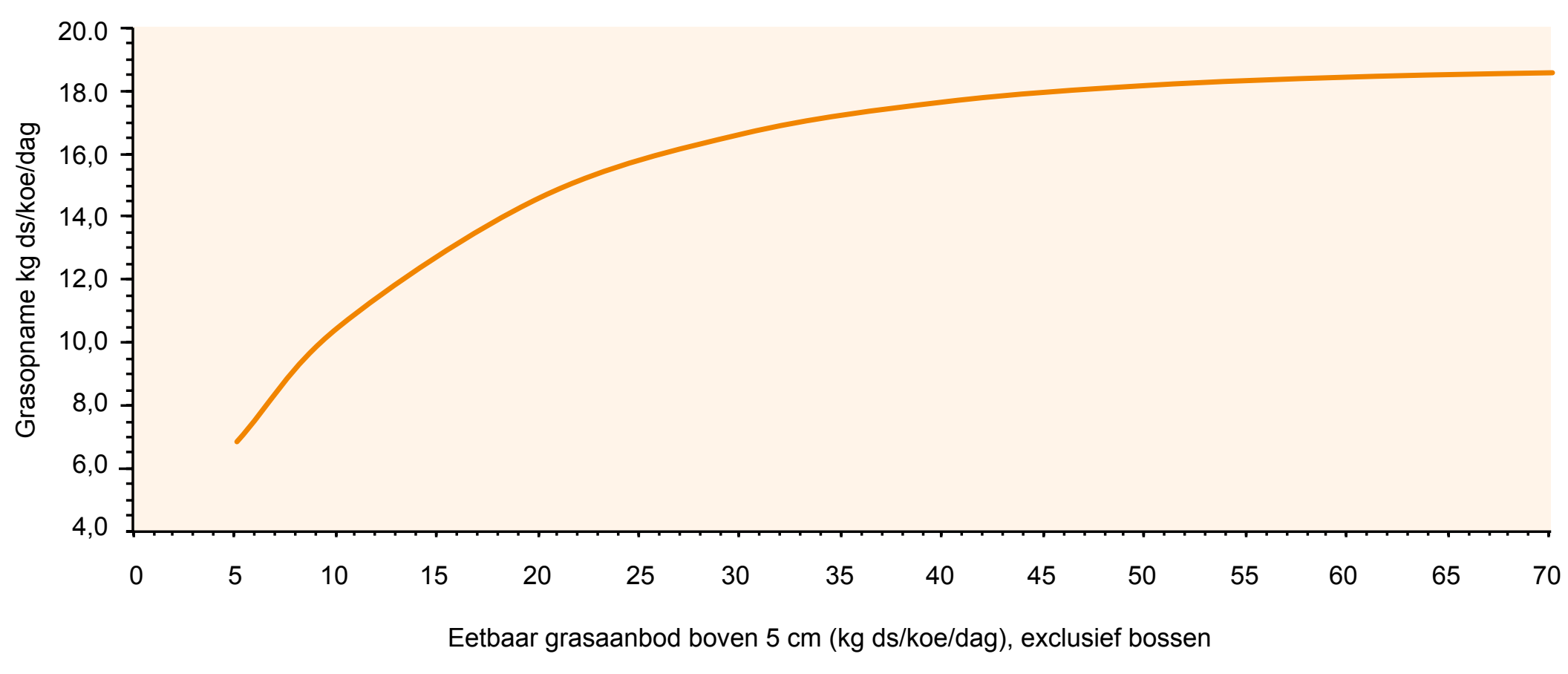

Maximale grasopname zonder bijvoeding in relatie tot het eetbare grasaanbod. In Amazing Grazing was het grasaanbod op Dairy Campus bij stripgrazen ongeveer 4-6 kg ds per dier per dag. Bij roterend standweiden ongeveer 5-10 kg ds per dier per dag

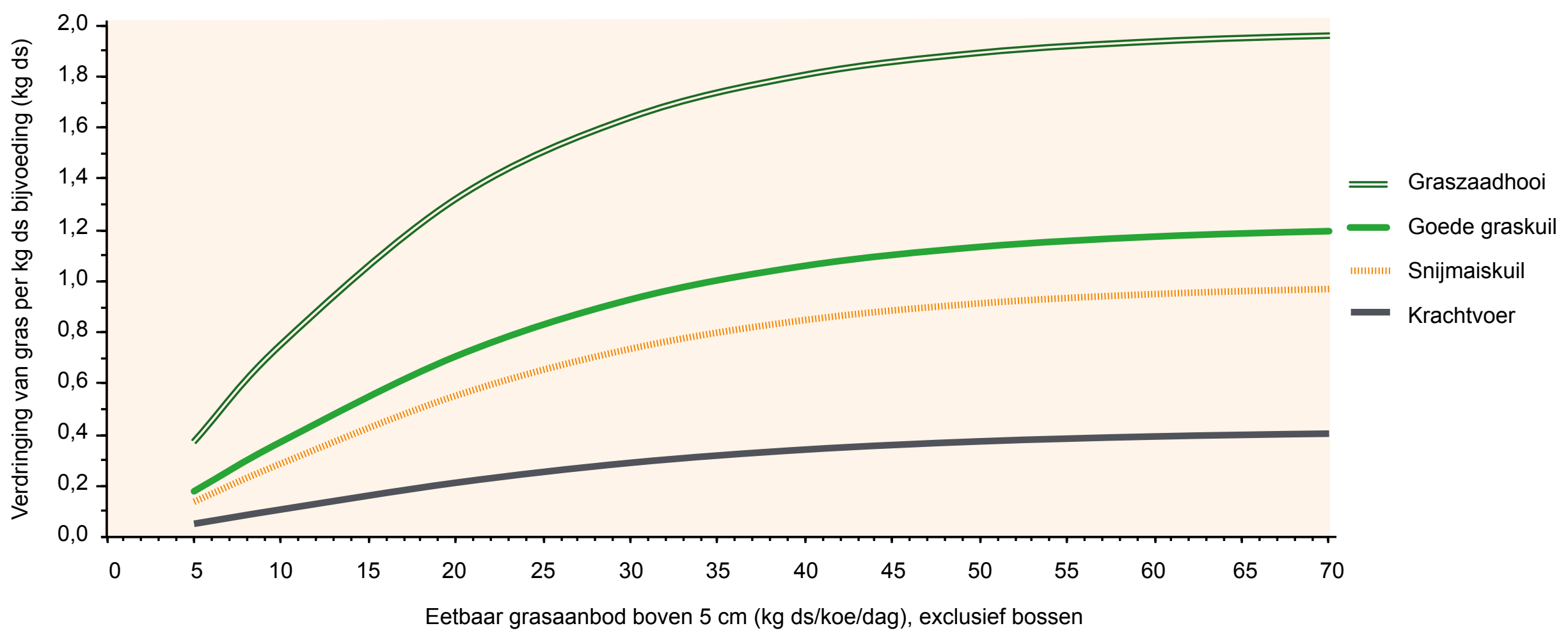

De verdringing van weidegras door krachtvoer, snijmais, graskuil en graszaadhooi - in relatie tot het grasaanbod
Bijvoeding

- Bijvoeding naast weidegras

- Verdringing weidegras

- Eiwit als graasmotivator

\begin{tabular}{|c|c|c|}
\hline Bijvoeding & Grasopname & Koegedrag \\
\hline Grasgroei & Bodem & Grasvoorraad \\
\hline
\end{tabular}




\section{Eiwit als graasmotivator}

Kunnen we grazende melkkoeien motiveren om meer eiwitrijk weidegras op te nemen via een laag eiwitaanbod in de bijvoeding? De beweidingsproeven van Amazing Grazing lieten zien dat het niet of nauwelijks het geval is.

\section{Balans}

Melkkoeien en andere herkauwers zijn in staat om zelf een redelijk constant dieet samen te stellen uit verschillende soorten voer, zodanig dat ze voldoende energie en eiwit opnemen. Eerder onderzoek liet zien dat melkkoeien, die op stal vrij konden kiezen tussen graskuilrantsoenen met een hoog en een laag pens afbreekbaar eiwitgehalte (OEB), zelf een dieet selecteerden met voldoende, maar niet teveel eiwit. In proeven met lammeren werd het wat spannender gemaakt door ze een basisrantsoen te geven met een onbalans in energie of eiwit. Daarna konden de lammeren in de weide vrij kiezen uit een aanbod van grassen en klaver met verschillende gehal-

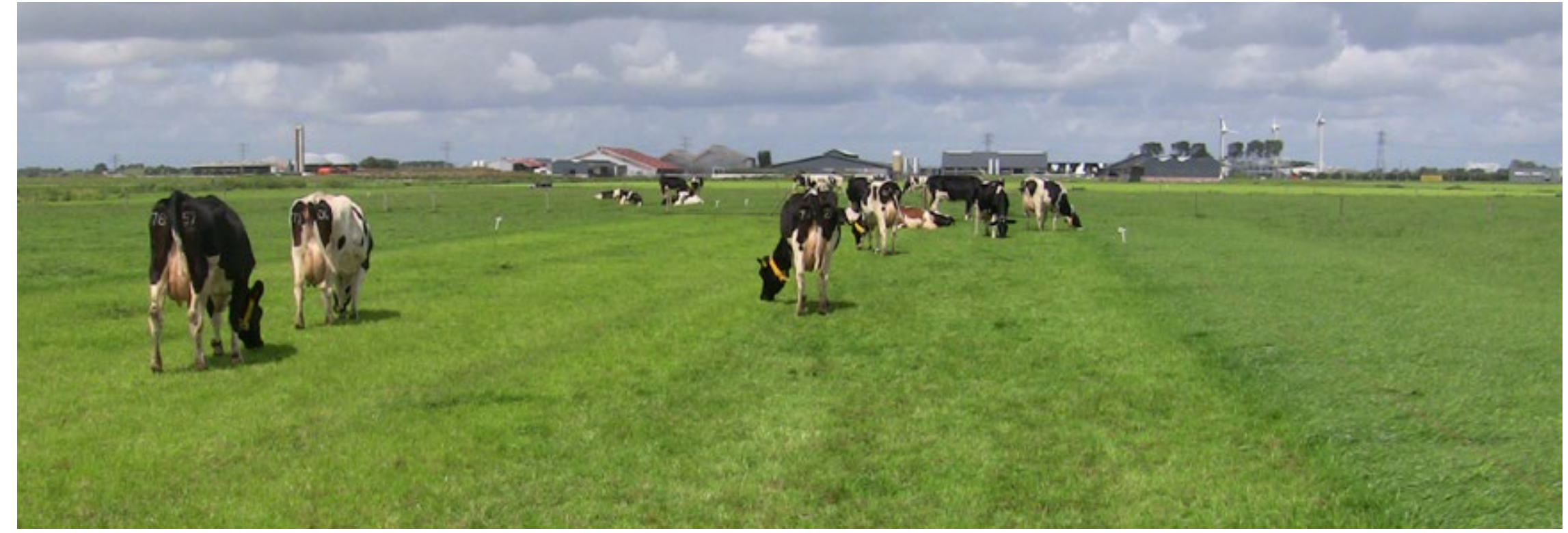

ten aan energie en eiwit. Het bleek dat ze in de weide inderdaad planten selecteerden die de onbalans in het basisrantsoen compenseerden. Bijvoorbeeld, bij een laag eiwitgehalte in het basisrantsoen selecteerden de lammeren grassen en klaver met een hoog eiwitgehalte. In Amazing Grazing vroegen we ons af of dat bij grazende melkkoeien ook zo zou kunnen werken.

\section{Proef op Dairy Campus}

In de beweidingsproeven van Amazing Grazing kregen de melkkoeien op stal, naast een vaste hoeveelheid snijmaïs, $6 \mathrm{~kg}$ krachtvoer met twee verschillende gehalten aan pensafbreekbaar eiwit, respectievelijk -50 en +50 gram OEB per kg droge stof. De vraag was of de melkkoeien met een eiwittekort in de bijvoeding, overdag in de weide meer gras zouden opnemen om het tekort te compenseren. In voorjaar, zomer en najaar van 2016 en 2017 is telkens gedurende één week de grasopname in de weide gemeten met de n-alkanen methode.

$$
\text { Lees verder }
$$

Bijvoeding

- Bijvoeding naast weidegras

- Verdringing weidegras

- Eiwit als graasmotivator

\begin{tabular}{|c|c|c|}
\cline { 2 - 3 } Bijvoeding & Grasopname & Koegedrag \\
\hline Grasgroei & Bodem & Grasvoorraad \\
\hline
\end{tabular}


Bijvoeding

\section{Grasopname}

De opname van weidegras werd niet wezenlijk beïnvloed door het eiwitniveau in de bijvoeding. Gemiddeld namen de melkkoeien bijna $6 \mathrm{~kg}$ droge stof op aan weidegras. In 2016 nam de opname in de loop van het seizoen geleidelijk af, vooral omdat het grasaanbod daalde. In 2017 daalde aanbod en opname pas in het najaar. Het is dus niet gelukt om koeien meer gras op te laten nemen door minder pensafbreekbaar eiwit in de stal aan te bieden. In 2016 was er mogelijk toch sprake van compensatie; de melkkoeien met een laag eiwitniveau in het rantsoen, lieten meer snijmais achter in de stal. Helaas leidde dit dus niet tot de gewenste hogere grasopname, maar een lagere snijmaisopname.

\section{Melkproductie}

In 2016 waren de droge-stofopname en melkproductie lager bij de behandeling met weinig eiwit, maar in 2017 waren er geen verschillen in droge-stofopname en melkproductie. Wellicht was in 2016 het OEB aanbod voor de behandeling met weinig

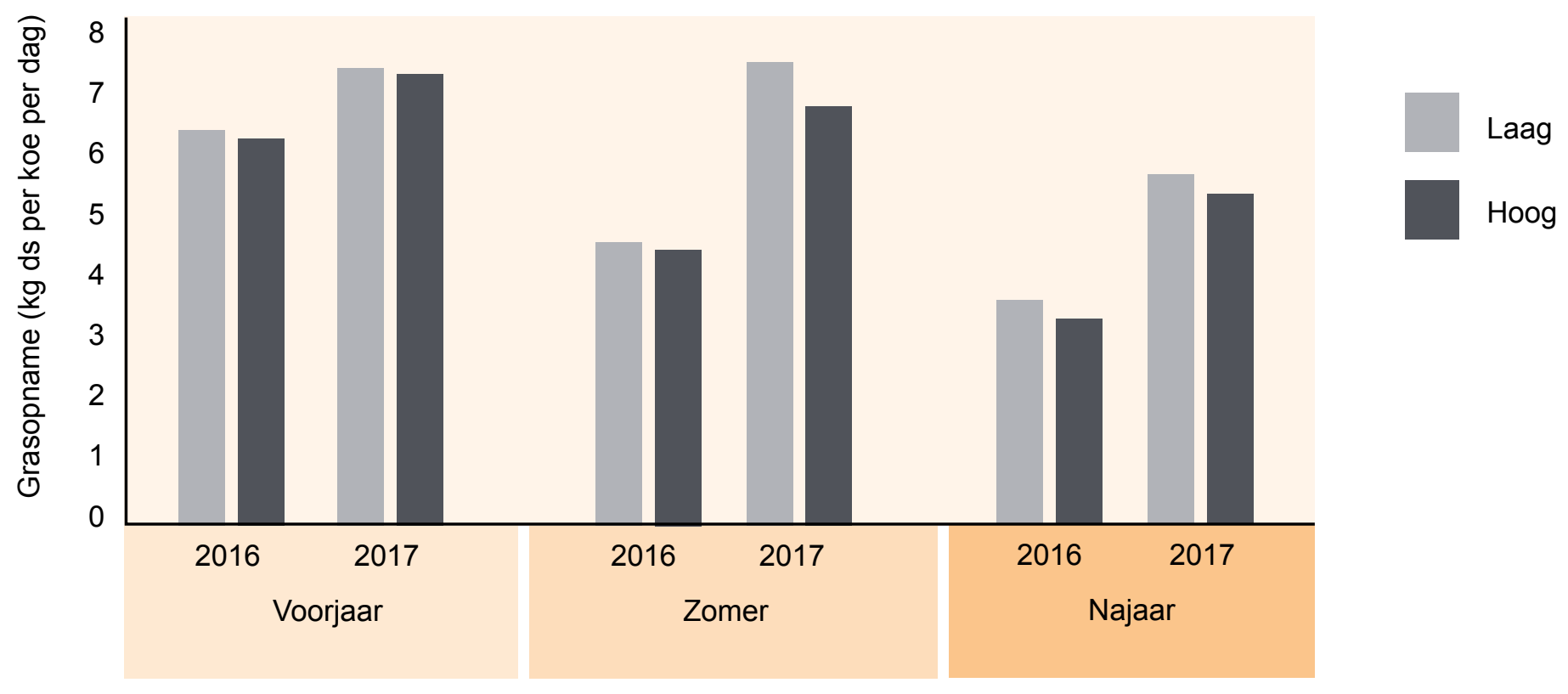

Gemiddelde opname van weidegras (kg ds per koe per dag) bij laag en hoog gehalte $(-50 \mathrm{~g}$ OEB $/ \mathrm{kg}$ ds en $+50 \mathrm{OEB} / \mathrm{kg}$ ds) van pensafbreekbaar eiwit in het krachtvoer in de beweidingsproeven op Dairy Campus in 2016 en 2017 eiwit te laag (tussen de -430 en -100 gram OEB per koe per dag). In 2017 was de totale hoeveelheid pensafbreekbaar eiwit in het rantsoen met weinig eiwit niet lager dan -260 gram OEB per koe per dag. Het is dus belangrijk het eiwitaanbod bij weiden in de gaten te houden om productieverlies te voorkomen.

\section{Verder lezen in rapporten \\ van Amazing Grazing}

- R. Zom, A. Bannink, L. Šebek, 2018. Effect of rumen degradable protein in concentrate on cow performance with two grazing strategies in 2016 2017. Feeding trials supplemental feeding with grazing. Wageningen UR Livestock Research,

Wageningen. Report 1164

- Zom et al., 2018. Can we motivate dairy cows to increase their grass intake by feeding low protein supplements? 27th General Meeting of the

European Grassland Federation (EGF), pp.407-409.

\section{Bijvoeding}

Bijvoeding naast weidegras

- Verdringing weidegras

- Eiwit als graasmotivator 
Gras efficiënt omzetten in melk, daar draait het om bij beweiding. Beweiden is gericht op een zo hoog mogelijke grasopname en -benutting door de koe. Het aanbod in de wei en de bijvoeding spelen daarbij een belangrijke rol. Daarbij draait het niet alleen om de hoeveelheid, maar ook om de kwaliteit van stalvoer en vers gras, en hun onderlinge afstemming.

\section{Grasopname}

- Hoe graast een koe? - Grasopname in de wei bepalen

Grasopname, weidetijd en vreettijd

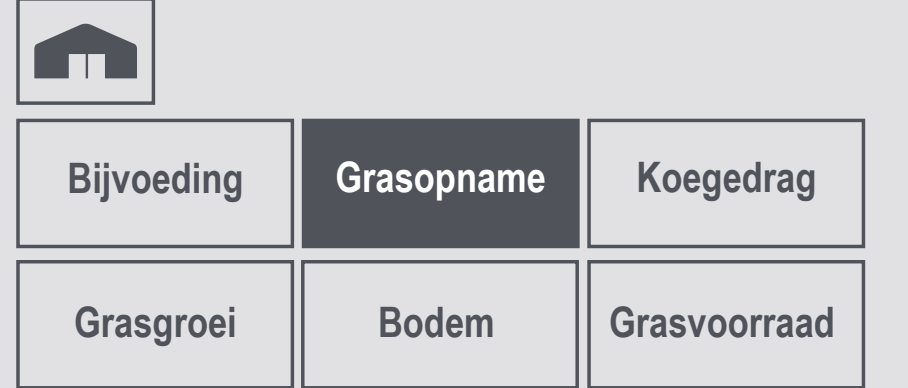

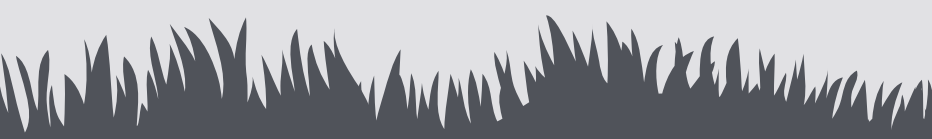




\section{Hoe graast een koe?}

Grazen omvat het hele proces van zoeken, 'oogsten' en verwerken van gras voordat de koe het gras inslikt. Het loont de moeite om eens wat langer naar je koeien te kijken om te zien wat er in de wei gebeurt.

Koeien die dag en nacht in de weide zijn, grazen grofweg zes tot elf uur per dag, verdeeld over drie tot vijf maaltijden. De twee hoofdmaaltijden zijn rond opkomst en ondergang van de zon. Daartussendoor worden kleinere maaltijden genoten, grotendeels overdag. Doorgaans grazen koeien 's nachts minder dan overdag, tenzij het overdag heel warm en vochtig is.

\section{Een hap gras}

Koeien nemen zo'n 45 tot 70 keer per minuut een hap gras. Met elke hap nemen ze ongeveer een halve gram droge stof aan gras op. De exacte hapgrootte hangt af van de zodedichtheid, de grashoogte, de ouderdom van het gras en het droge-stofgehalte van het gras. Een hap bestaat uit enkele snel opeenvolgende bewegingen. Allereerst omringen de tong en de lippen een pluk gras waarna het gras in de mond wordt getrokken, tussen de snijtanden van de onderkaak en de tandeloze bovenkaak. Vervolgens snijdt en scheurt de koe het gras af met een abrupte beweging van de kaak en het hoofd waarbij het hoofd iets

Lees verder

Wiskunde in de Wei

Grasopname

[gram droge stof per koe per dag]

$=$ Graasduur $\quad x$ Hapfrequentie $x$ Hapgrootte $=$ [minuten per dag] $\times$ [happen per minuut] $\times$ [gram droge stof per hap]

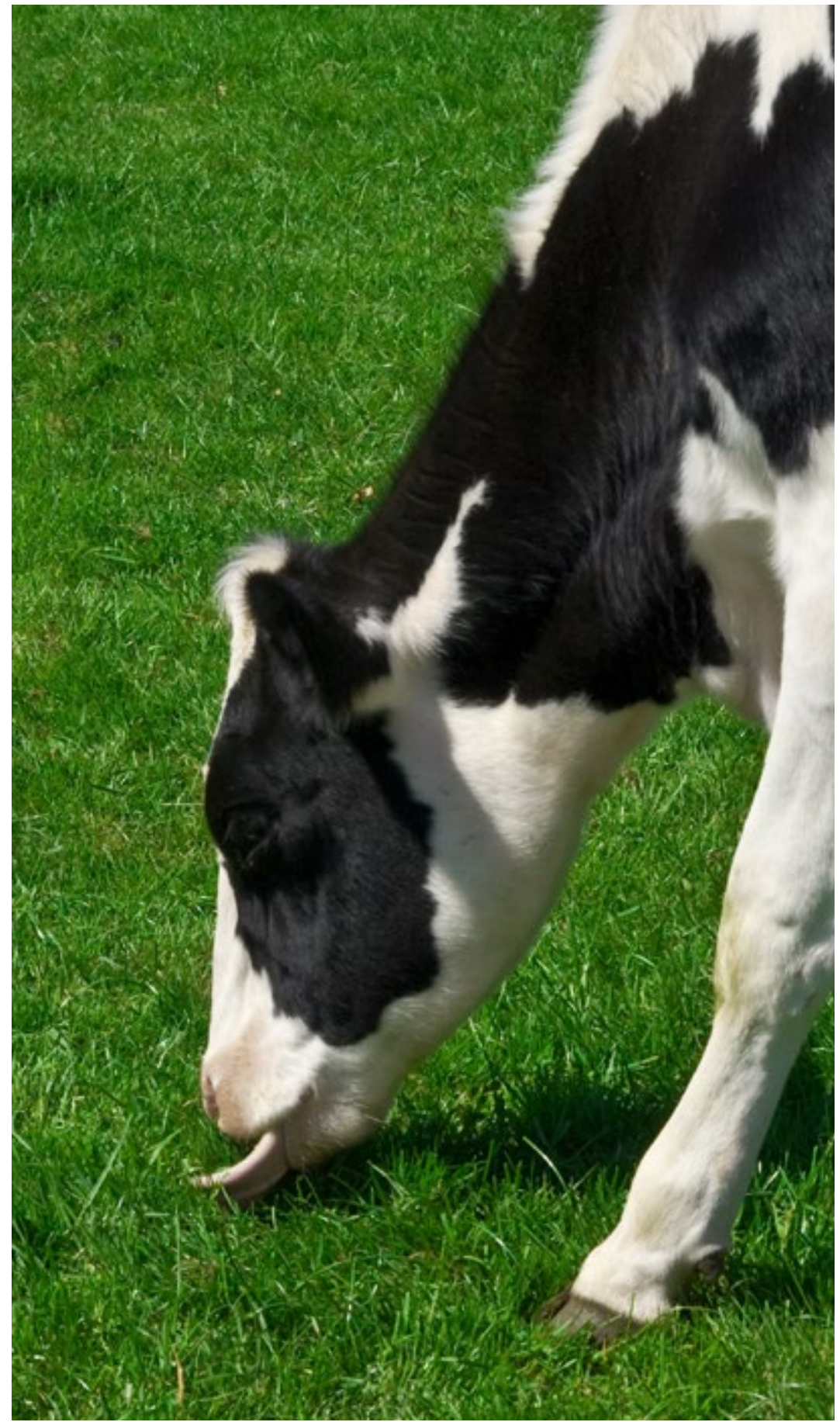

$1 / 2$
Grasopname

- Hoe graast een koe?

-Grasopname in de wei bepalen

- Grasopname, weidetijd en vreettijd

\begin{tabular}{|c|c|c|}
\hline \multicolumn{2}{|c|}{} \\
\hline Bijvoeding & Grasopname & Koegedrag \\
\hline \hline Grasgroei & Bodem & Grasvoorraad \\
\hline
\end{tabular}

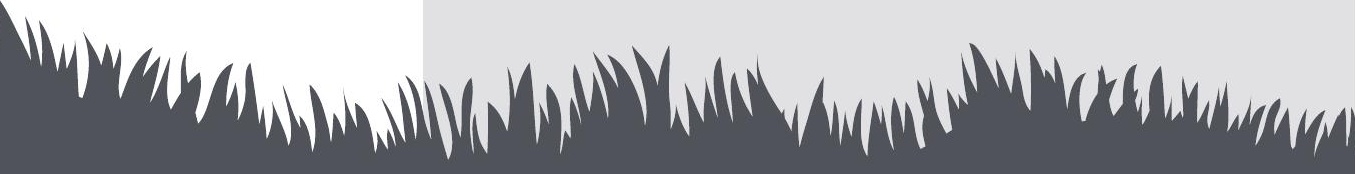


omhoog komt vanuit de zode. Na het kauwen en slikken is de hap afgerond.

\section{Verse graasplek}

Een koe graast niet in één keer de volledige hoeveelheid gras op een plek weg, maar scheert als het ware een laagje ervan af. Op zoek naar het lekkerste gras, besluit ze om op dezelfde plek een laagje dieper te grazen of een stap te zetten om bij een verse graasplek te komen. De exacte strategie is afhankelijk van het beweidingssysteem en de daarmee samenhangende weidetijd en grashoogte. Naarmate het gras korter is, neemt de hapgrootte af. Koeien compenseren dat door de hapfrequentie op te voeren. Toch is dat onvoldoende om bij kort gras dezelfde opname per minuut te realiseren als bij lang gras. Om voldoende gras binnen te krijgen zullen koeien bij korter gras langer moeten grazen.

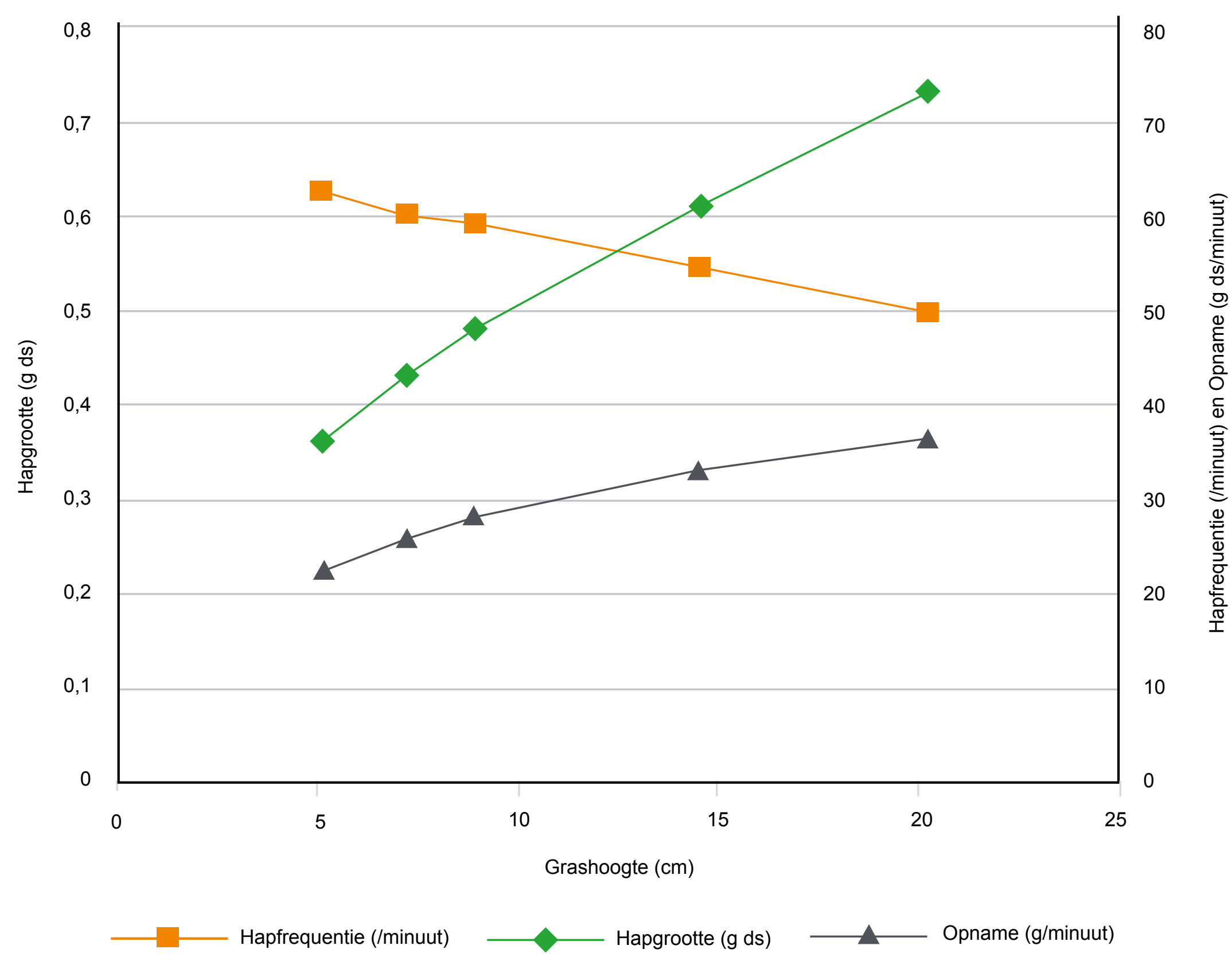

Verband tussen grashoogte, hapgrootte, hapfrequentie en opname van melkkoeien in Engels onderzoek
- Hoe graast een koe?

Grasopname in de wei bepalen

Grasopname, weidetijd en vreettijd

\begin{tabular}{|c|c|c|}
\hline Bijvoeding & Grasopname & Koegedrag \\
\hline Grasgroei & Bodem & Grasvoorraad \\
\hline
\end{tabular}




\section{Grasopname in de wei bepalen}

Goed weiden draait om een zo hoog mogelijke grasopname. Het meten of schatten van de opname in de wei is echter niet eenvoudig. Hieronder zetten we de voor- en nadelen van drie methoden op een rij die we in Amazing Grazing hebben gebruikt.

\section{Klassieker}

De meest directe manier om de grasopname te bepalen is het meten van de grasopbrengst bij in- en uitscharen. Het verschil in de hoeveelheid gras tussen in- en uitscharen is dan opgenomen door de groep grazende koeien. Bij deze methode wordt de grashoeveelheid gemeten door het uitmaaien van stroken gras met een speciale kleine maaier. Deze klassieke methode werkt goed bij een korte beweidingsduur zoals stripgrazen. Bij een langere beweidingsduur moet je de opname corrigeren met de bijgroei tijdens beweiding. Dat kan door kooien te plaatsen waaronder de on-

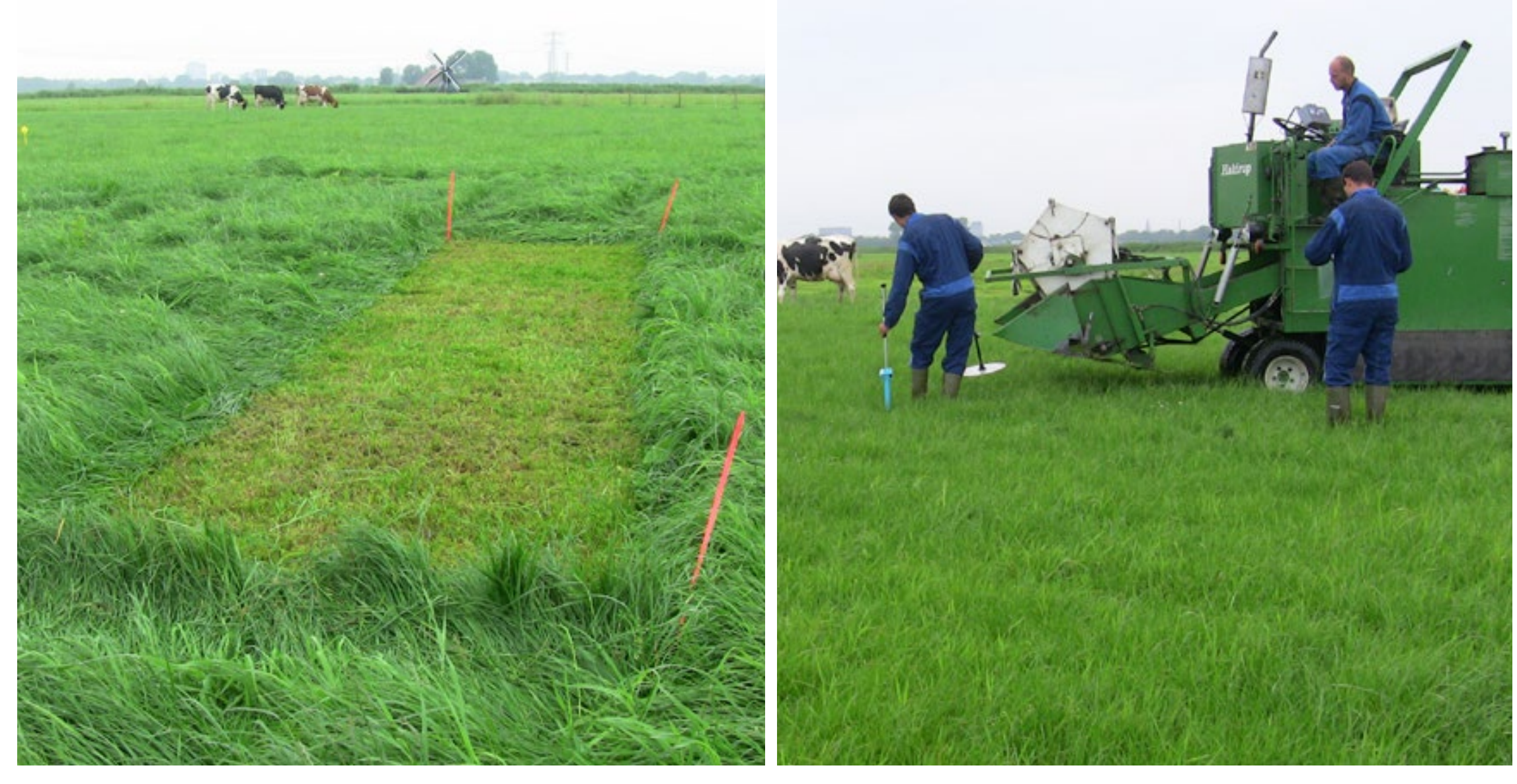

verstoorde bijgroei tijdens beweiding wordt gemeten.

\section{Grashoogtemeter}

Het uitmaaien van stroken is een tijdrovende klus. Een alternatief is het gebruik van grashoogtemeters. Dat gaat een stuk snel- ler, is dus goedkoper, maar minder nauwkeurig. Bij grashoogtemeters wordt de grashoogte gerelateerd aan de opbrengst. Daarbij wordt vaak een standaard formule benadering is niet altijd goed bruikbaar.

$$
\text { Lees verder }
$$
gebruikt. Echter, deze 'one size fits all'
Grasopname

- Hoe graast een koe? Grasopname in de wei bepalen

- Grasopname, weidetijd en vreettijd 
Daarom worden in onderzoek grashoogtemeters geijkt met behulp van een beperkt aantal werkelijke opbrengstmetingen in uitgemaaide stroken. Per seizoen en per type grasland gebruik je een andere formule waarmee de opbrengst uit de grashoogte te berekenen is.

\section{Grasresten}

$\mathrm{Bij}$ een langere beweidingsduur op een perceel, zoals bij roterend standweiden is opbrengstmeting niet alleen lastiger vanwege de correctie voor de bijgroei, maar ook vanwege een toenemende bosvorming in het grasland. Het is dan moelijker om representatieve maaistroken aan te leggen of een representatieve grashoogte te meten.

\section{$\mathrm{N}$-alkanen methode}

In de jaren tachtig van de vorige eeuw is een nieuwe methode ontwikkeld om op een slimme manier de grasopname van weidende dieren te meten. De zogenaamde n-alkanen methode maakt gebruik van de aanwezigheid van lange onverteerbare koolstofketens die in de waslaag van gras zitten. In gras komen van nature n-alkanen voor met een oneven aantal koolstofatomen (C25, C27, C29, C31, C33, C35) en nagenoeg geen $\mathrm{n}$-alkanen met een even aantal C-atomen. Bij deze methode krijgen koeien speciaal krachtvoer met een bekende hoeveelheid $n$-alkanen met een even aantal C atomen (C32). De grasopname wordt vervolgens berekend aan de hand van de verhouding tussen C32 en C33 in

\begin{tabular}{rcccc} 
& Geschikt voor & Periode & Nauwkeurigheid & Kosten \\
\hline Energiedekking & Koppel & Weideseizoen & Redelijk & Laag \\
\hline n-alkanen & Dier & Dag & Goed & Hoog \\
\hline Grashoogte & Koppel & Dag & Matig & Redelijk \\
\hline
\end{tabular}

Samenvattend overzicht van methoden voor bepalen grasopname

mest, en de gehalten aan C32 en C33 in weidegras, krachtvoer en overige bijvoeding. De n-alkanen methode is geschikt om de grasopname van individuele dieren te meten, maar is een bewerkelijke en dure aanpak die alleen voor onderzoeksdoeleinden verantwoord is.

\section{Praktijk}

De eenvoudigste manier is het schatten van de grasopname als restpost van de VEM-behoefte minus de VEM-opname uit bijvoeding. VEM (VoederEenheid Melk) geeft de energiebehoefte of het energie-aanbod uit voedermiddelen weer in VEM per dier per dag en VEM per kg droge stof. De totale VEM-behoefte is de som van de behoeften voor melkproductie, onderhoud, dracht, en toeslagen voor jeugdgroei, fysieke activiteit en weidegang. Uit voedingsonderzoek blijkt dat de VEM-opname gemiddeld $2 \%$ hoger is dan de VEM-behoefte. Daarom wordt de behoefte gecorrigeerd met $+2 \%$. Als de VEMopname uit voedermiddelen zoals kracht-

Lees verder
Grasopname

- Hoe graast een koe? Grasopname in de wei bepalen

- Grasopname, weidetijd en vreettijd

(n)

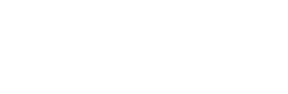

(1)

\begin{tabular}{|c|c|c|}
\hline Bijvoeding & Grasopname & Koegedrag \\
\hline Grasgroei & Bodem & Grasvoorraad \\
\hline
\end{tabular}


voer, kuilvoer en bijproducten bekend is, kan de VEM-opname uit weidegras eenvoudig berekend worden als het verschil tussen de totale VEM-behoefte en de VEM-opname uit bijvoeding. Tot slot wordt de VEM-opname uit weidegras gedeeld door het VEM-gehalte van weidegras, en is de opname in $\mathrm{kg}$ droge stof bekend. De methode is gevoelig voor onjuiste schattingen van de voederwaardes en voor afwijkingen in de werkelijke VEM-behoefte, bijvoorbeeld door ziekte.

Deze methode is vooral geschikt voor de schatting van de opname voor een hele koppel en een compleet seizoen. Daarom wordt deze methode ook toegepast in de KringloopWijzer en bij berekeningen van het CBS over de jaarlijkse grasopname van de gehele Nederlandse veestapel.

\section{Meetweken}

In 2016 en 2017 is in het beweidingsonderzoek op Dairy Campus de grasopname op verschillende manieren gemeten en geschat. Ten eerste zijn in 2016 en 2017 drie intensieve meetweken uitgevoerd waarin de individuele opname met $\mathrm{n}$-alkanen is gemeten. Gemiddeld namen de melkkoeien $5,5 \mathrm{~kg}$ droge stof per dag op, met een variatie van drie tot zeven $\mathrm{kg}$ droge stof per dag. De opname, berekend uit de grashoogtemetingen lag gemiddeld $35 \%$ lager dan de berekening volgens de n-alkanen. Bovendien was de spreiding

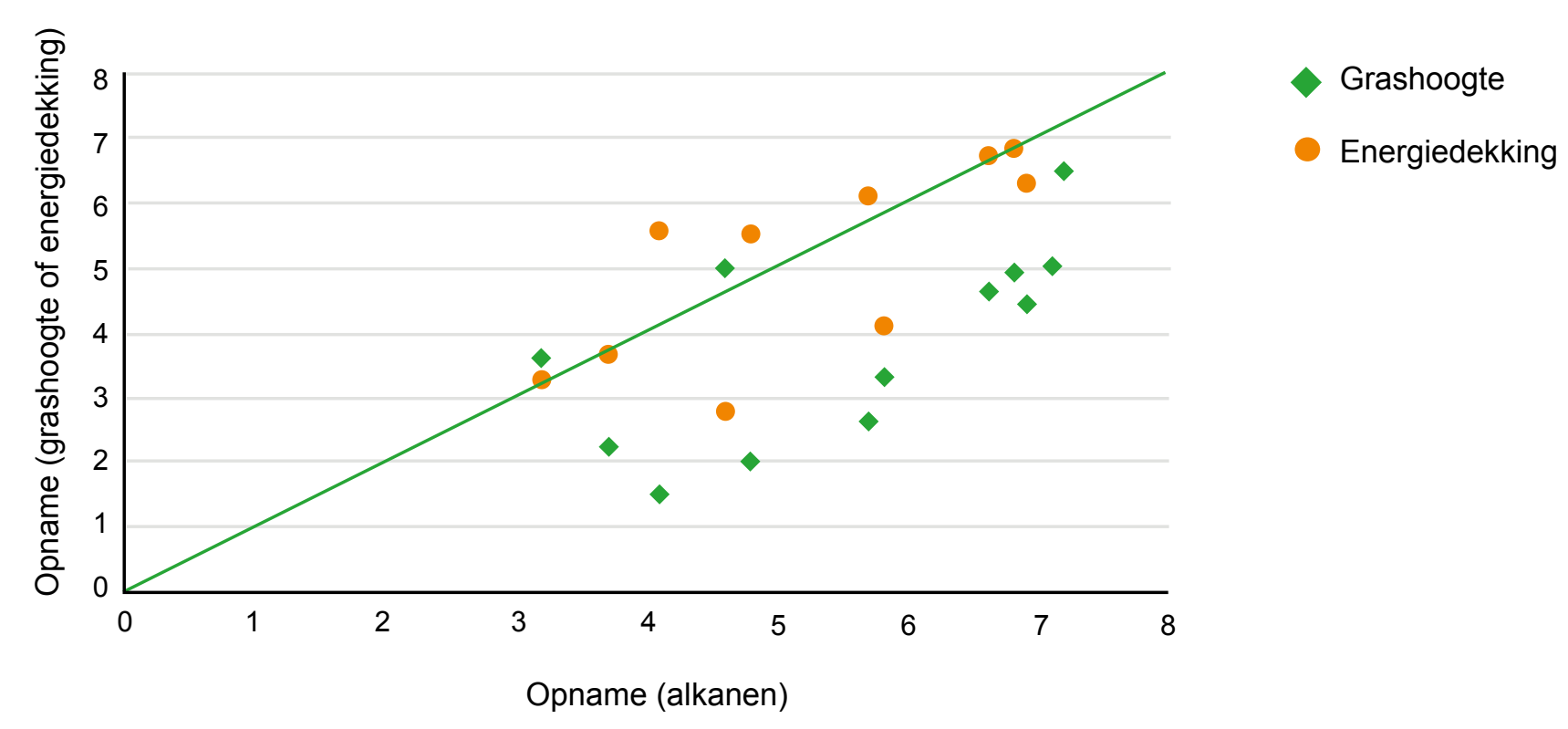

Vergelijking van de grasopname in de weide ( $\mathrm{kg} \mathrm{ds} / \mathrm{koe} / \mathrm{dag}$ ), berekend met behulp van grashoogtemetingen en energiedekking ten opzichte van $n$-alkanen. De metingen zijn uitgevoerd gedurende zes meetweken in 2016 en 2017 bij stripgrazen en roterend standweiden wat groter; van 1,5 tot $6,5 \mathrm{~kg}$ droge stof per dag. De opname, berekend uit de energiebehoefte liet een beter beeld zien, met een gemiddelde overschatting van de opname van slechts $3 \%$ ten opzichte van de $n$-alkanen methode met een relatief kleine spreiding.

$$
\text { Lees verder }
$$




\section{Weideseizoen}

Twee methoden, grasopname en energiebehoefte, zijn ook over het gehele weideseizoen vergeleken. Daaruit komt grofweg hetzelfde beeld: de opname volgens de grashoogte is lager dan volgens de energiebehoefte, al is het verschil wat kleiner dan eerder geconstateerd in de meetweken. In 2016 was het verschil tussen beide methoden vrij klein, maar in 2017 waren de verschillen groot, met name bij stripgrazen. Mogelijk heeft dat te maken met de hoeveelheid doorgeschoten gras in de weide waarvoor de methode met grashoogten erg gevoelig is.

\section{Verder lezen in rapporten}

van Amazing Grazing

- R. Zom, A. Bannink, L. Šebek, 2018. Effect of rumen degradable protein in concentrate on cow performance with two grazing strategies in 2016 2017. Feeding trials supplemental feeding wit grazing. Wageningen UR Livestock Research, Wageningen. Report 1164.

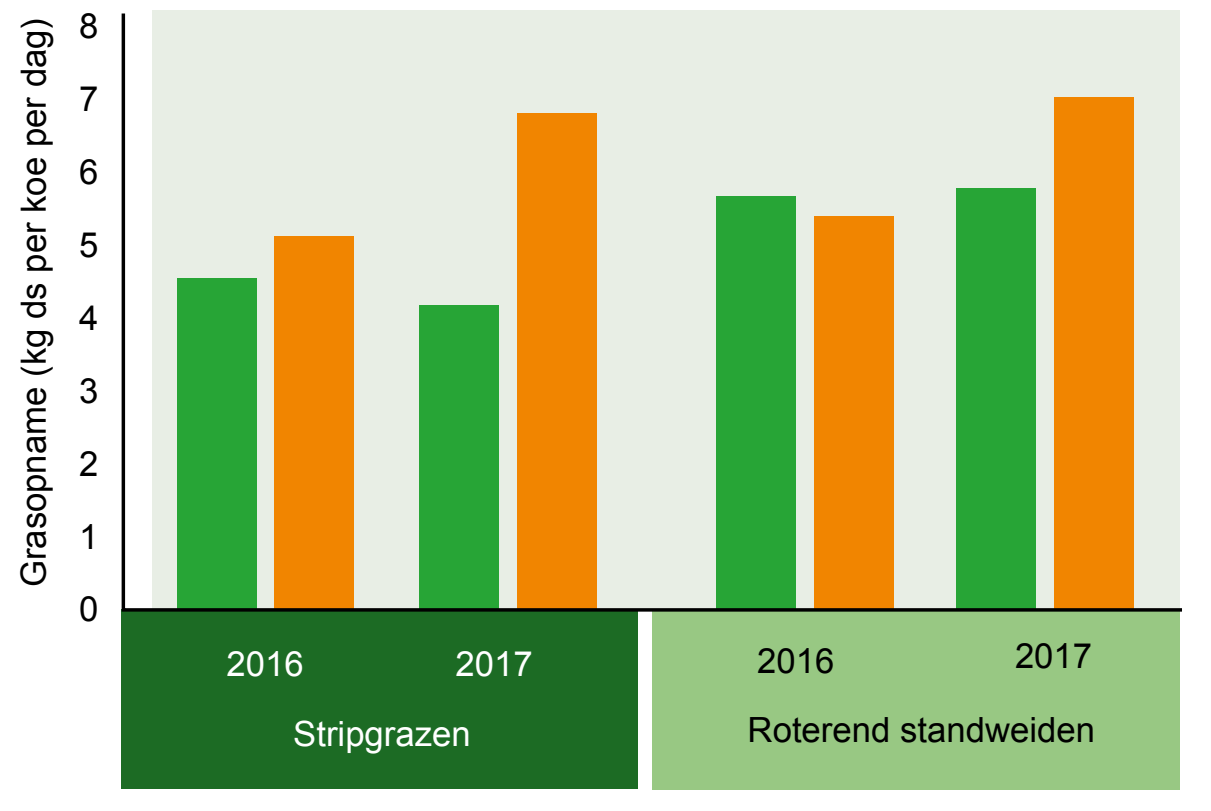

Grashoogte

Energiedekking

Vergelijking van de grasopname in de weide, berekend met behulp van grashoogte metingen en energiedekking De metingen zijn uitgevoerd gedurende het gehele weideseizoen in 2016 en 2017 bij stripgrazen (SG) en roterend standweiden (RSW)
- Hoe graast een koe?

Grasopname in de wei bepalen

Grasopname, weidetijd en vreettijd

\begin{tabular}{|c|c|c|}
\hline Bijvoeding & Grasopname & Koegedrag \\
\hline Grasgroei & Bodem & Grasvoorraad \\
\hline
\end{tabular}




\section{Grasopname, weidetijd en vreettijd}

Een zeer grove vuistregel die we vaak gebruiken voor de opname van weidegras is een kilogram droge stof per uur weidegang. Hieronder zetten we de relatie tussen weidetijd, vreettijd en opname op een rijtje voor de verschillende jaren en beweidingssystemen in Amazing Grazing.

\section{Weidetijd en vreettijd}

In Amazing Grazing is beweid volgens de principes van stripgrazen, roterend standweiden en kurzrasen; alle drie met een hoge veebezetting van 7,5 koe per hectare op de beweidbare oppervlakte. Op Dairy Campus weidden de koeien overdag, tussen de zeven en acht uur per dag, met bijvoeding van snijmais. Op KTC Zegveld weidden de koeien gedurende de nacht, zo'n twaalf uur per dag, met bijvoeding van graskuil. De gemiddelde werkelijke vreettijd was op Dairy Campus vier uur per dag en op Zegveld vijf uur per dag, respectie-

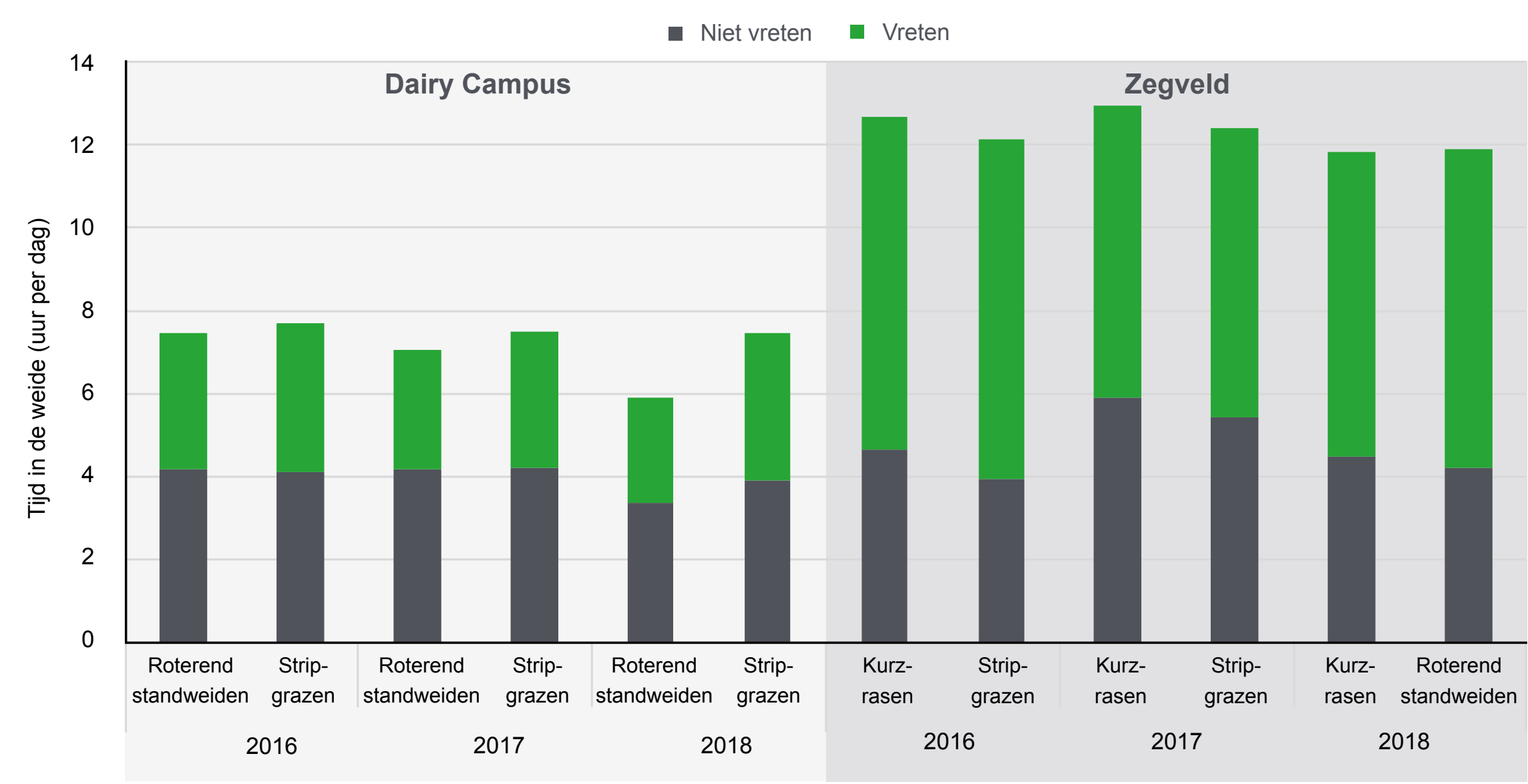

Totale weidetijd en vreettijd van de koeien in de beweidingssystemen van Amazing Grazing; gemiddelde waarden van de Holstein koeien bij een veebezetting van 7,5 koe per ha. In 2017 en 2018 eindigden de weideseizoenen op Dairy Campus respectievelijk al in begin september en eind juli

velijk $55 \%$ en $40 \%$ van de totale tijd in de weide. Op Dairy Campus was er geen consistent verschil in de vreettijd bij stripgrazen en roterend standweiden. Op Zegveld was de vreettijd bij Kurzrasen gemid- deld een half uur langer dan bij stripgrazen of roterend standweiden. Bovenstaande cijfers gelden voor Holstein koeien.

$$
\text { Lees verder } \Rightarrow
$$

\section{Grasopname}

- Hoe graast een koe? Grasopname in de wei bepalen

Grasopname, weidetijd en vreettijd 
Op Zegveld bestond de helft van de koppel uit Jersey kruislingen; zij vraten gemiddeld ruim een half uur langer dan de Holsteins, ongeacht het beweidingssysteem.

\section{Grasopname in de wei}

Over het hele seizoen was de gemiddelde grasopname ruim zes $\mathrm{kg}$ droge stof per koe per dag, met slechts kleine verschillen tussen de locaties en beweidingssystemen. Er waren vooral verschillen tussen de jaren; de opname was in 2017 gemiddeld ruim zeven en in 2018 bijna vijf kg droge stof per koe. De grasopname in de weide is berekend als sluitpost van het verschil tussen de VEM-behoefte en de VEM-opname uit krachtvoer en ruwvoer. Bij kurzrasen dienen we een extra slag om de arm te houden omdat het lastig is om een representatieve schatting te maken van de VEM-inhoud van het extreem korte gras.

Lees verder

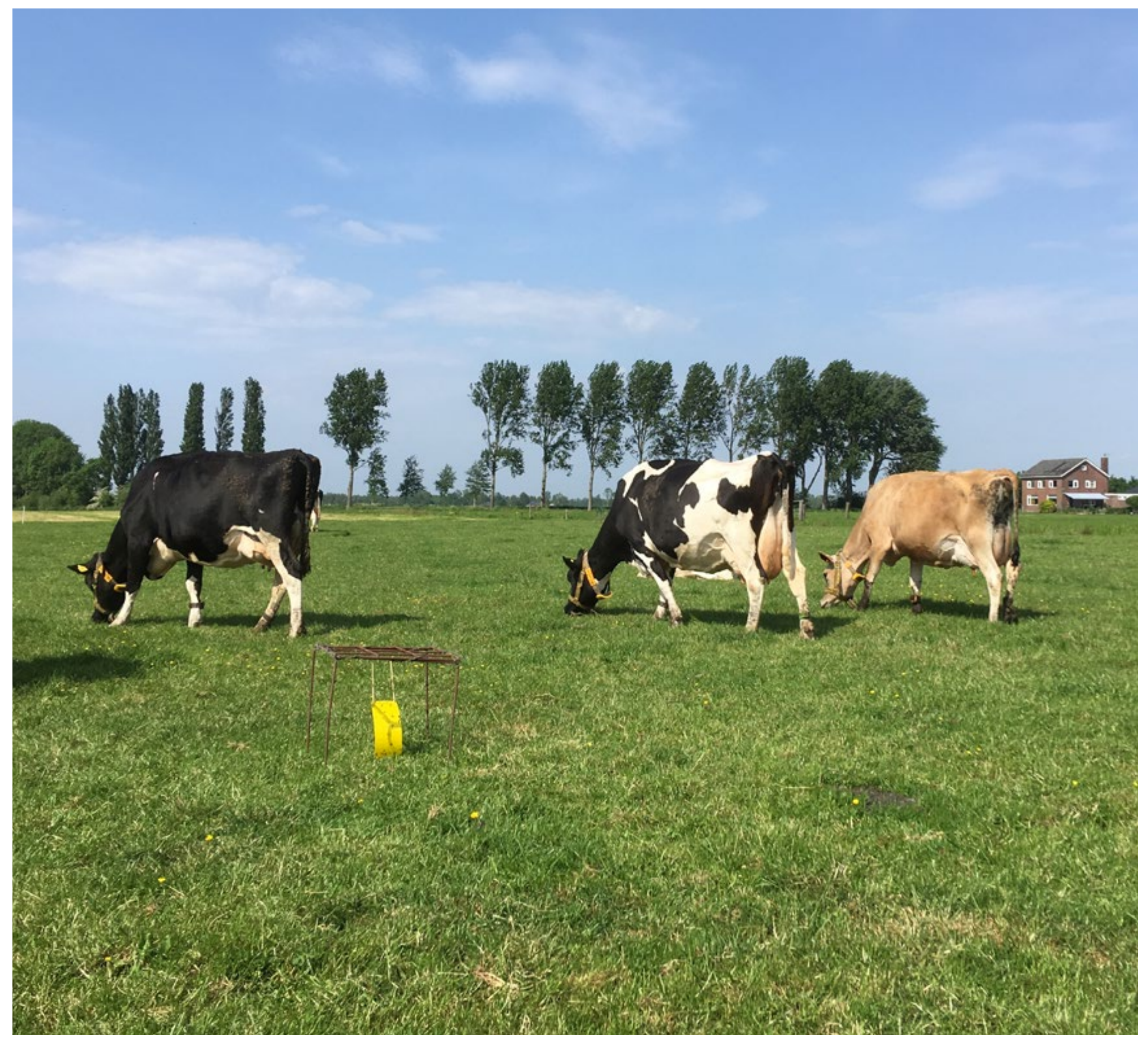

Grasopname

- Hoe graast een koe?

Grasopname in de wei bepalen

Grasopname, weidetijd en vreettijd 


\section{Grasopname per uur weidetijd}

Op Dairy Campus was de gemiddelde grasopname $0,8 \mathrm{~kg}$ droge stof per uur weidetijd bij zeven uur weiden voor Holsteins. Op Zegveld was dit 0,4 kg droge stof bij twaalf uur weiden met een gemengde $\mathrm{Hol}-$ stein-Jersey veestapel. Er waren geen grote verschillen tussen de beweidingssystemen. Op Dairy Campus was de opname per uur wat hoger bij roterend standweiden. Verschillen tussen de jaren liepen verder uiteen.

\section{Vreettijd}

De opname per uur vreettijd is mogelijk een betere maat om te vergelijken over systemen met verschillende beweidingsduur heen. Op Dairy Campus was de opname per uur vreettijd bij Holsteins $1,5 \mathrm{~kg}$ droge stof; op Zegveld was dit met de Holstein-Jersey veestapel $1,1 \mathrm{~kg}$ droge stof Evenals bij de opname per uur weidetijd waren er geen consistente verschillen tussen de beweidingssystemen. Op Zegveld was de opname per uur vreettijd wat hoger bij stripgrazen dan bij kurzrasen.

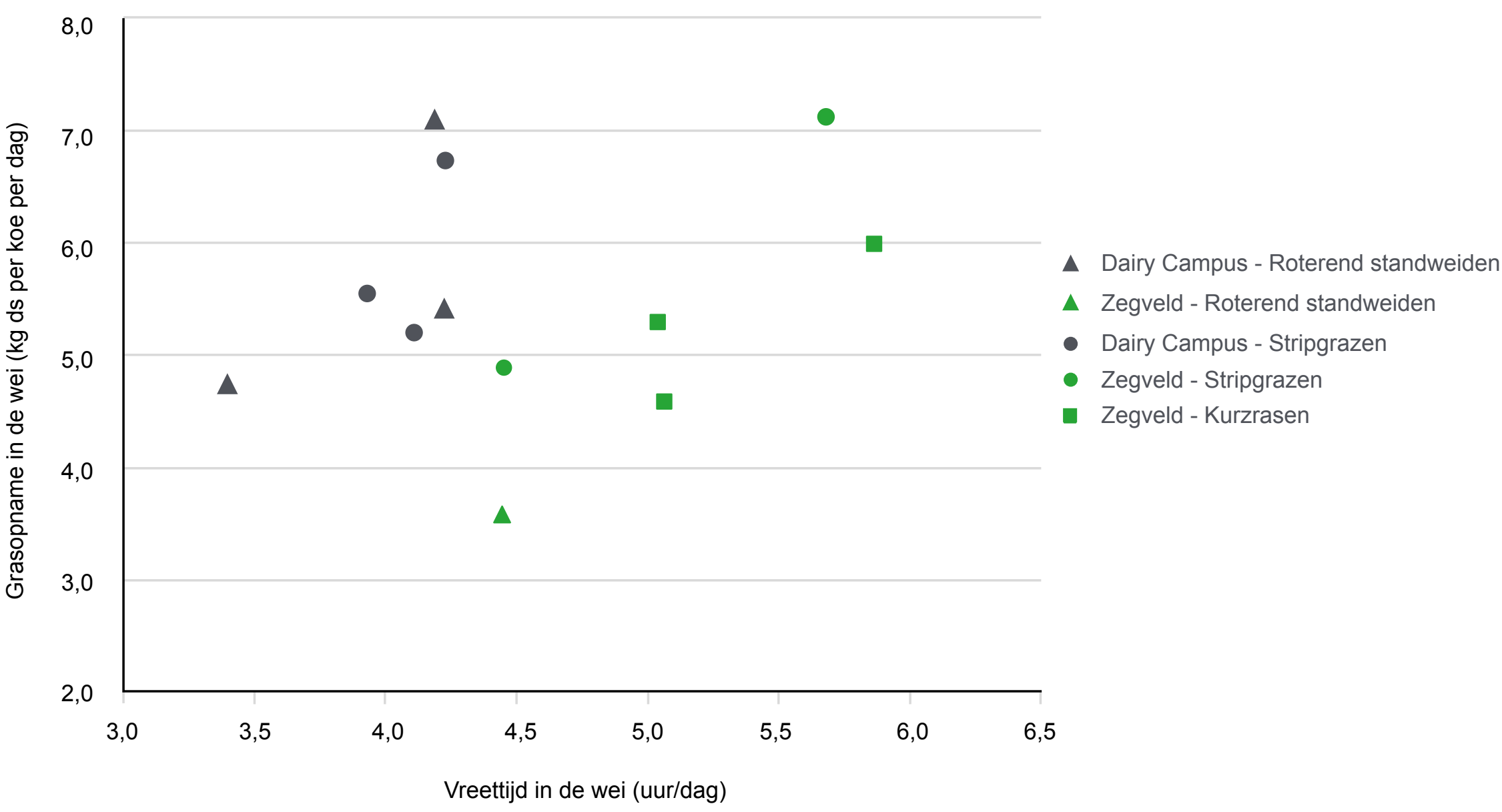

Verband tussen grasopname en vreettijd in de weide voor de Holstein koeien op Dairy Campus $(D C)$ en de gemengde Holstein-Jersey veestapel op Zegveld (ZV). (RSW = roterend standweiden; $S G=$ stripgrazen; $K R=$ kurzrasen)
Grasopname

Hoe graast een koe? Grasopname in de wei bepalen

Grasopname, weidetijd en vreettijd

\begin{tabular}{|c|c|c|}
\hline \multicolumn{2}{|c|}{} \\
Bijvoeding & Grasopname & Koegedrag \\
\hline Grasgroei & Bodem & Grasvoorraad \\
\hline
\end{tabular}

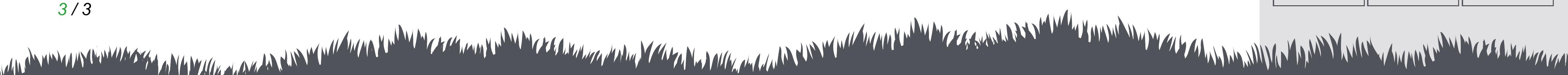





\section{Sociale koeien}

Koeien zijn kuddedieren. Toch houden sommige dieren liever wat meer afstand tot soortgenoten. Wat betekent dit voor het gedrag in de wei?

\section{Sociale motivatie test}

Sociabiliteit is de motivatie van individuele dieren om in de buurt van soortgenoten te verblijven. Het kan zich uiten in de afstand die dieren tot elkaar houden in een grazende koppel of in gelijktijdigheid van gedrag. Kennis over sociabiliteit van individuele koeien is belangrijk omdat het ons kan helpen met een slimme groepsindeling of misschien zelfs bij het ontwerp van beweidingssystemen. Maar voor we zover zijn, moeten we eerst een goede maat hebben voor sociabiliteit. Daarvoor is een zogenaamde sociale motivatie test gebruikt. Daarin wordt een koe op het kavelpad tijdelijk afgezonderd van een groep koppelgenoten. Vervolgens wordt ze weer losgelaten en wordt de tijd gemeten die ze neemt om haar koppelgenoten tot op 5 of 2 meter te naderen.

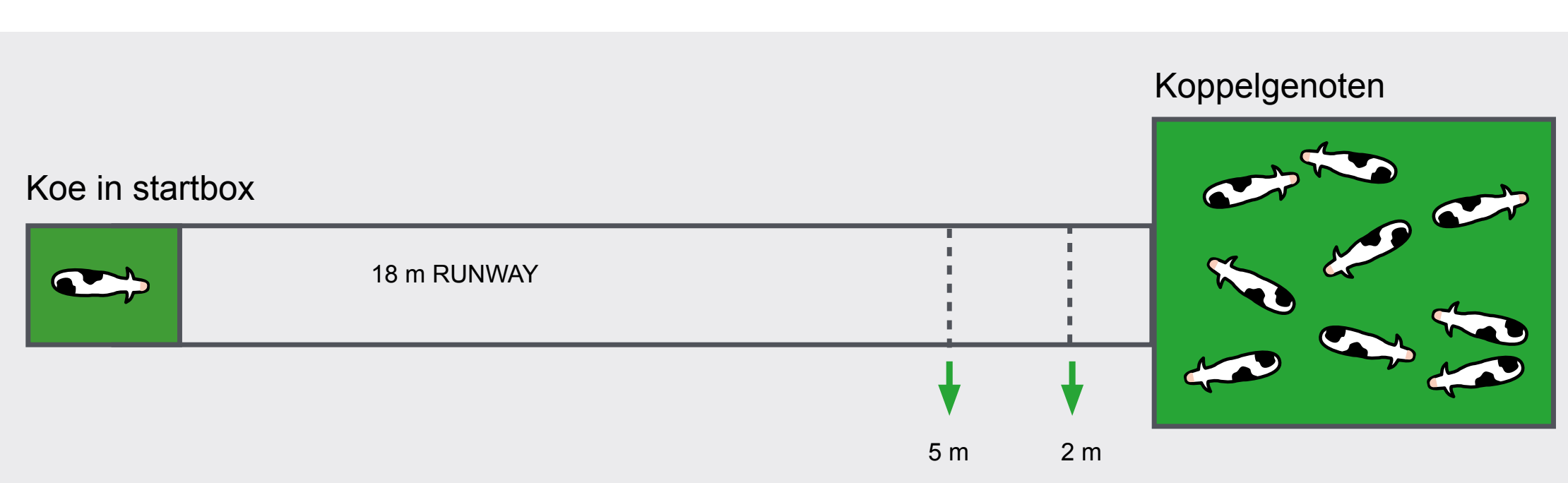

Sociale-motivatie-test met melkkoeien zoals die is uitgevoerd op Dairy Campus. In de test wordt de tijd gemeten die de alleenstaande koe (links) erover doet totdat zij op 5 of 2 meter afstand van de koppel is genaderd (rechts). De test is uitgevoerd op het kavelpad in een zogenaamde 'runway', bestaande uit een 18 meter lange gang met aan het ene uiteinde een zogenaamde 'startbox' en aan het andere uiteinde een afgezet gedeelte met een groep koppelgenoten van de te testen koe. Voor de test wordt de te testen koe in de startbox geplaatst en het toegangshek tot de runway geopend.

\section{Grote variatie}

De metingen laten grote verschillen zien tussen de dieren. Sommige koeien zijn in een paar tellen bij de koppelgenoten, terwijl andere na vijf minuten nog geen aanstalten hebben gemaakt. De sociale motivatie test is twee keer, met 8 weken
De test start als de koe met beide voorpoten de startbox heeft verlaten. De tijd wordt gemeten totdat de koe met beide voorpoten een lijn op respectievelijk 5 en 2 meter afstand van de men wordt dat koeien met relatief korte latentietijden (of test-looptijden) vanaf de start van de test tot het moment dat ze zich op 5 of 2 meter afstand van hun koppelgenoten bevinden een hoge motivatie hebben om dichtbij soortgenoten in de buurt te zijn (een hoge sociabiliteit) en dieren met relatief lange latentietijden een lage motivatie (een lage sociabiliteit).

daartussen, uitgevoerd. Daaruit blijkt dat de reactie van individuele dieren in beide tests heel consistent is. Dat ondersteunt het idee dat de motivatie van koeien om in de buurt van soortgenoten te verblijven een dierkenmerk is.

Lees verder groep koppelgenoten is gepasseerd. Aangeno-
Koegedrag

- Sociale koeien

- Schatting dagelijkse grasopname in wei

- Dagbesteding in de wei 


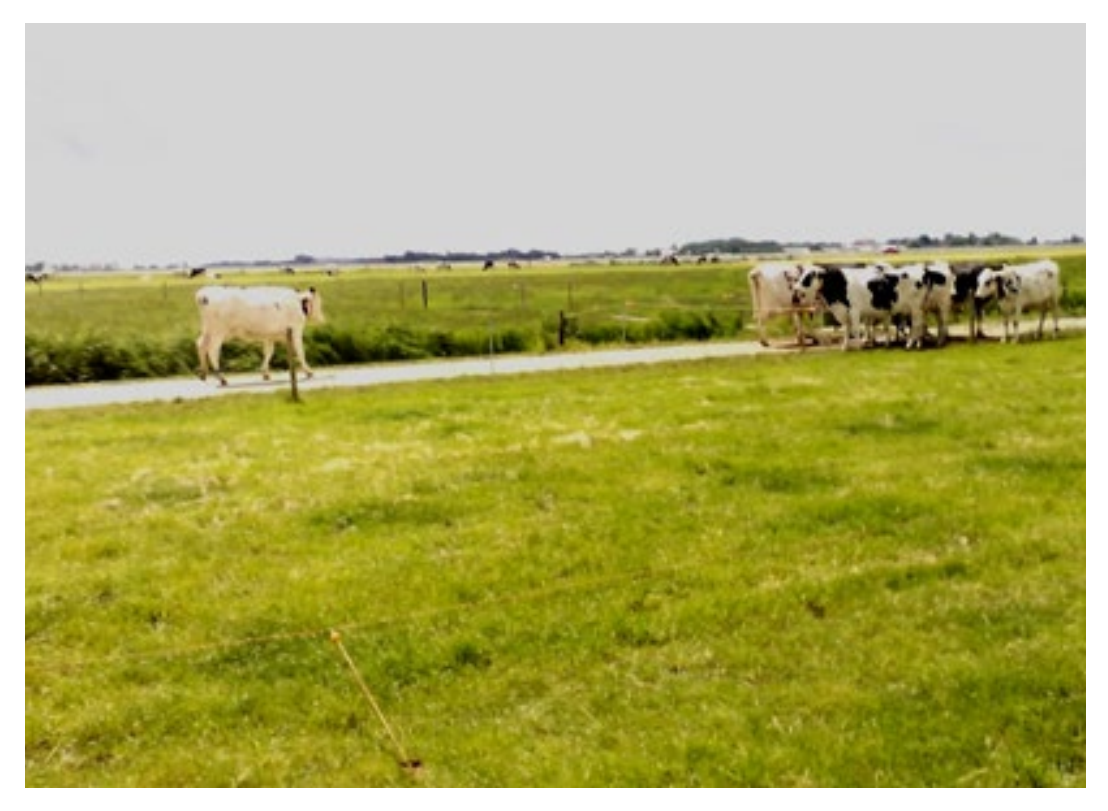

\section{Onderlinge afstand in de wei}

Tijdens de periode van 8 weken tussen de twee sociale motivatie tests zijn dezelfde koeien nauwkeurig geobserveerd in de wei. Op ruim 100 tijdstippen is de onderlinge afstand tussen de koeien geschat. Koeien met een hoge sociale score uit de sociale motivatie test zijn ook in de weide vaker dichter bij elkaar te vinden dan koeien met een lage sociale score.

Gedurende één weideseizoen is eveneens de gelijktijdigheid van het sta- en liggedrag gevolgd met behulp van een pootsensor. Per kwartier is gekeken of individuele

\section{Gelijktijdigheid}

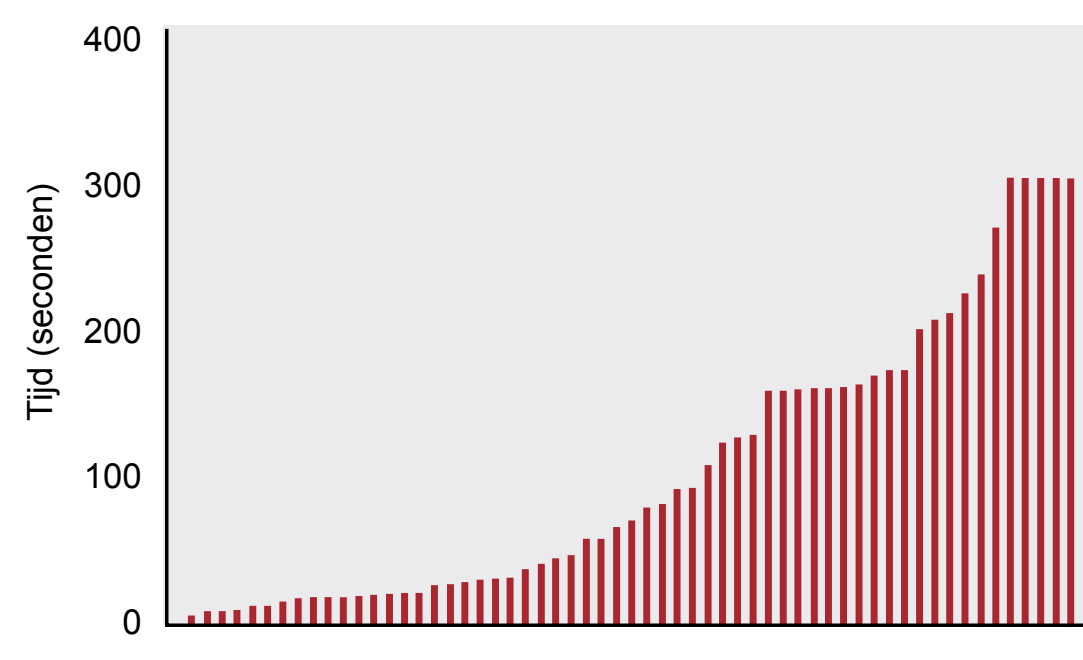

De wachttijd van individuele koeien voordat ze de koppel tot op 2 meter zijn genaderd

koeien meegingen in het dominante groepsgedrag van de rest van de koppel of dat ze zich als buitenbeentje gedroegen.

Daaruit bleek dat de meelopers de sociale koeien met een korte test-looptijd waren, terwijl de buitenbeentjes een langere test-looptijd hadden laten zien tijdens de sociale-motivatie test.

\section{Lessen voor beweiding}

Deze gedragsstudies in Amazing Grazing zijn een eerste poging om te leren van de individuele persoonlijkheid van koeien. Wat het precies betekent en hoe we kennis hierover nuttig kunnen toepassen voor doelgericht weiden, zowel in conventionele als in melkrobot systemen, is nu nog niet helemaal scherp. We weten nu dat de mate van sociabiliteit, de motivatie om dicht bij soortgenoten in de buurt te zijn, een stabiel gedragskenmerk is van individuele koeien. Bovendien is dit kenmerk gerelateerd aan de mate waarin individuele koeien hun gedrag synchroniseren met het gedrag van hun koppelgenoten tijdens weidegang. Vervolganalyses op een beperkte dataset binnen het project Amazing Grazing laten zien dat koeien die synchroner zijn met de koppel ('meelopers') langer grazen en meer gras opnemen dan buitenbeentjes.

\section{Verder lezen in rapporten van Amazing Grazing}

- Van Reenen et al., 2016. Sociability in grazing dairy cows is related to individual social network properties and behavioural synchrony. ISAE, Edinburgh.

\section{$2 / 2$}

Koegedrag

- Sociale koeien

- Schatting dagelijkse grasopname in wei

- Dagbesteding in de wei 


\section{Schatting dagelijkse grasopname in wei}

De grasopname in de weide is lastig vast te stellen. Bovendien komt die informatie met de nodige vertraging beschikbaar. Met behulp van gedragssensoren zijn we in staat om de grasopname redelijk en snel in te schatten.

\section{Halssensoren schatten vreettijd}

De melkkoeien op Dairy Campus zijn voorzien van drie verschillende sensoren die het gedrag van het dier volgen. Oorsensoren meten de herkauwtijd, pootsensoren meten de bewegingen rondom liggen, staan en lopen, terwijl halssensoren de vreettijd meten. De vreettijd in de wei is een maat voor de graastijd en is belangrijk om de schatting van de opname in de weide te verbeteren. Voorafgaand aan het onderzoek in Amazing Grazing zijn de halssensoren uitvoerig in detail getoetst en vergeleken met de handmatig door waarnemers gemeten vreettijd. Daaruit bleek dat de vreettijd gemeten met de halssensoren zeer goed overeenkomt met de werkelijke vreettijd.

\section{Meetweken}

In 2015, 2016 en 2017 zijn op Dairy Campus acht intensieve meetweken uitgevoerd waarin de individuele grasopname in de weide met de zogenaamde n-alkanen methode is gemeten. Deze maakt gebruik van de aanwezigheid van lange onverteerbare koolstofketens die in de waslaag van gras zitten. Hoe het precies werkt, is uitgelegd in de paragraaf 'Grasopname in de wei bepalen'. Naast de grasopname, zijn circa dertig andere kenmerken vastgelegd waarmee mogelijk een verband bestaat met de grasopname in de weide. Dat waren ten eerste de gedragsdata uit de sensoren, zoals hierboven is omschreven.

$$
\text { Lees verder }
$$

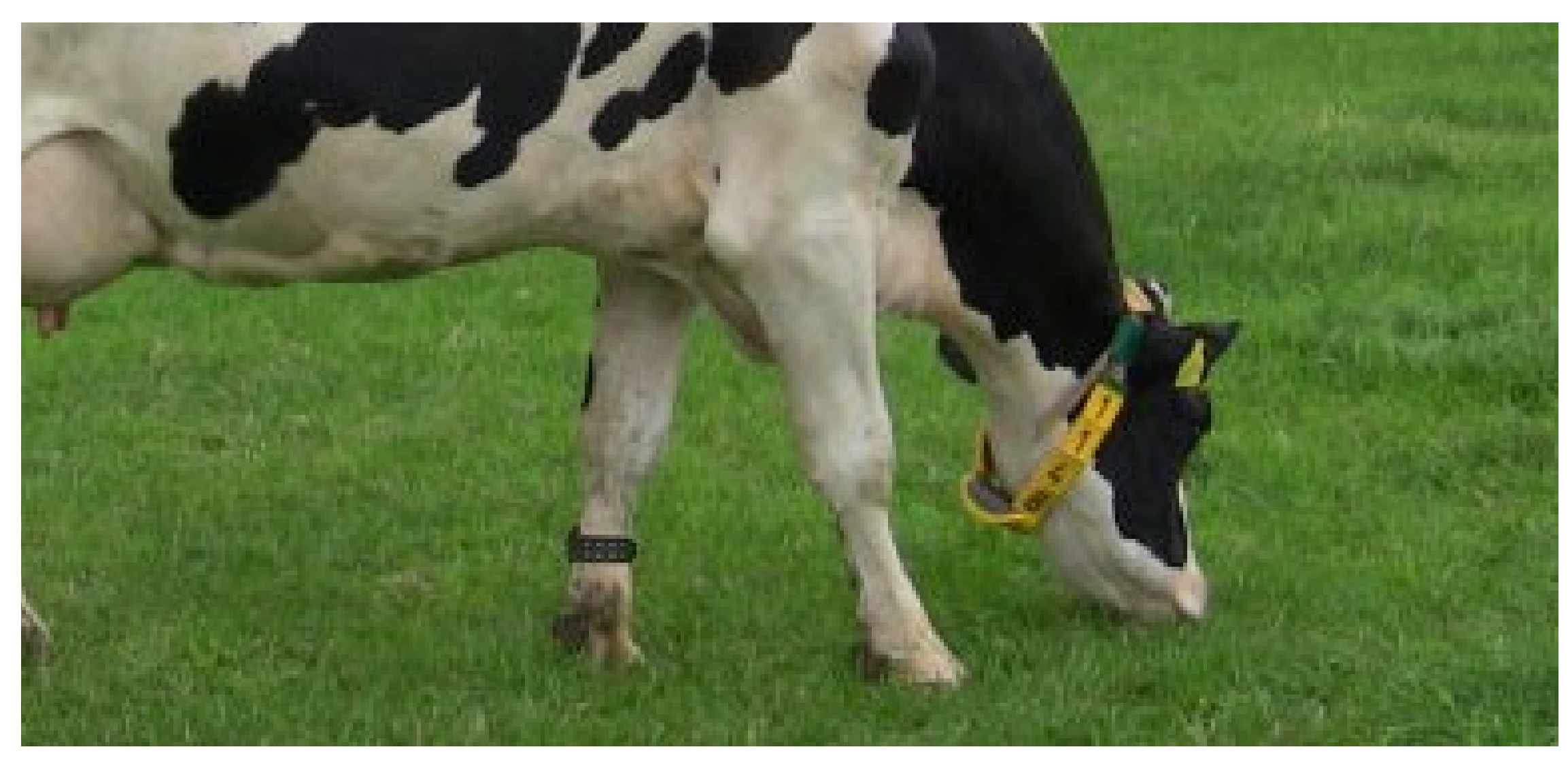

Koegedrag

- Sociale koeien

- Schatting dagelijkse grasopname in wei

- Dagbesteding in de wei 
Daarnaast zijn dierkenmerken zoals gewicht, leeftijd, dagen in melk en natuurlijk melkproductie en -kwaliteit vastgelegd. Alle bijvoeding zoals krachtvoer en ruwvoer is ook gemeten. Tot slot zijn verschillende variabelen gemeten die met het grasaanbod samenhangen, zoals grashoogte, graskwaliteit en de oppervlakte per dier.

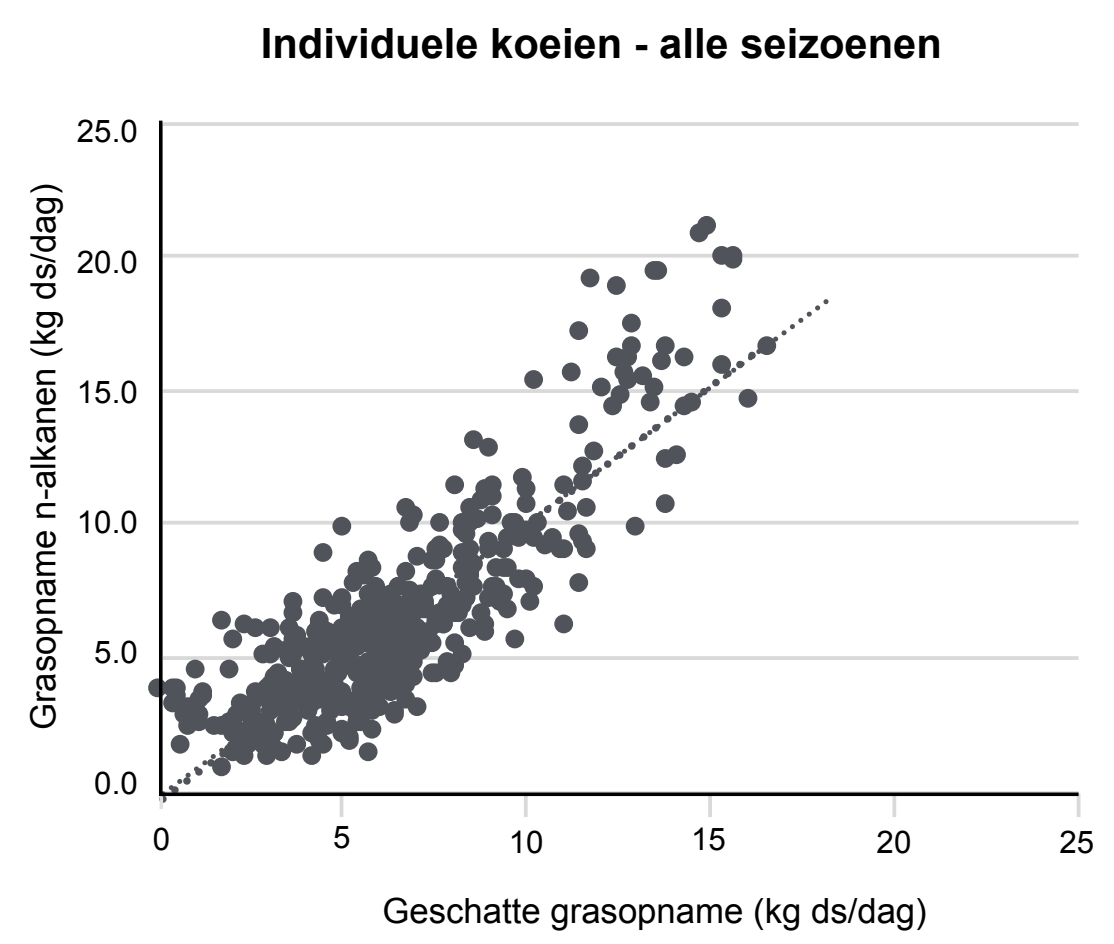

\section{Model}

In een uitgebreide analyse is het verband tussen alle gemeten kenmerken en de werkelijke grasopname in de weide vastgesteld. Daaruit rolden twee mogelijke modellen. Het beste model met de hoogste voorspelnauwkeurigheid bestond uit elf kenmerken. Echter een aantal van deze

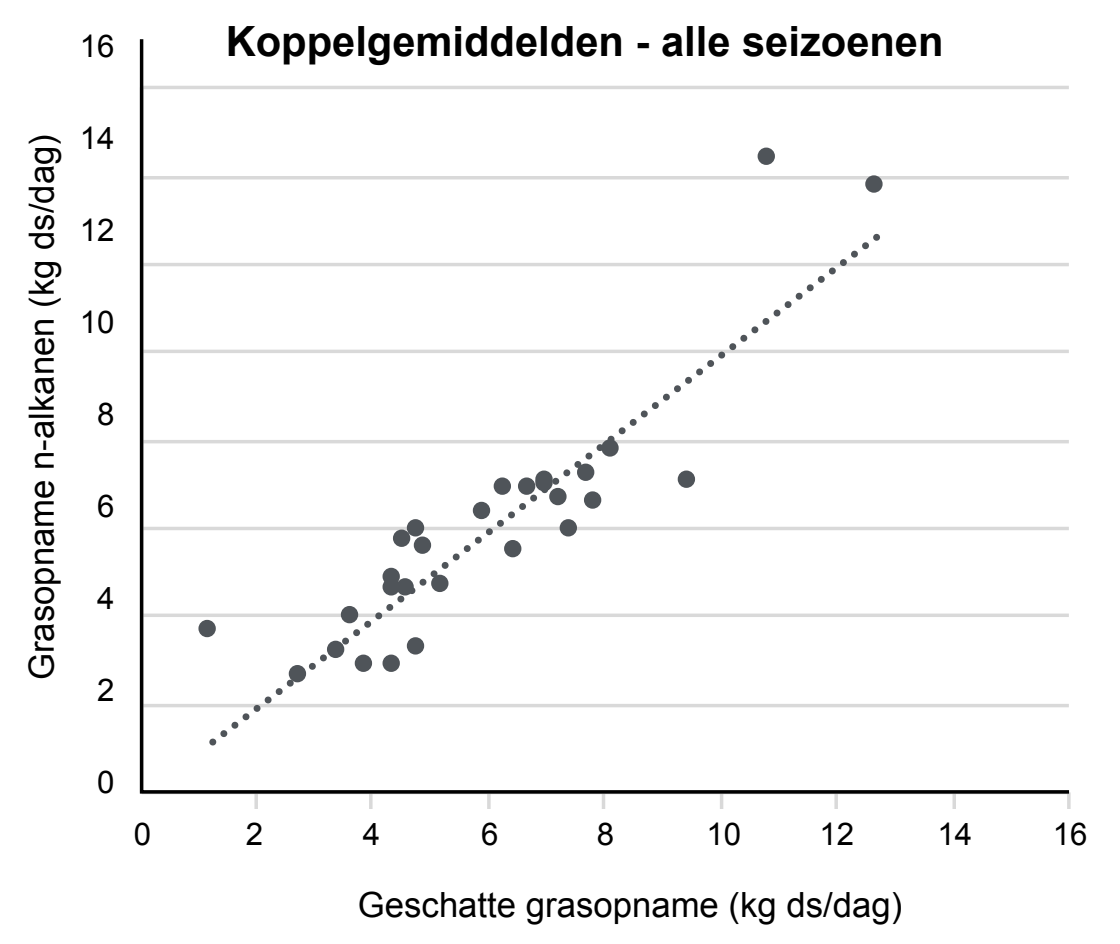

kenmerken, met name de hoeveelheid gras in de wei, is niet dagelijks beschikbaar op melkveebedrijven. Daarom is ook een 'praktisch haalbaar' model ontwikkeld. Dat bestaat uit vijf kenmerken die in de weideperiode vastgelegd worden: melkproductie, lactatienummer, dagen in lactatie, vreettijd en aantal stappen. Hiermee is het mogelijk om op koppelniveau met een onzekerheid van één kilogram droge stof de grasopname in de weide te berekenen. Dit opent de mogelijkheid om op bedrijven met hals- en pootsensoren dagelijks informatie te krijgen over de grasopname in de weide.
Koegedrag

Sociale koeien

- Schatting dagelijkse grasopname in wei

- Dagbesteding in de wei

Het verband tussen de werkelijke grasopname, gemeten met de $n$-alkanen methode, en de geschatte grasopname met het vereenvoudigde praktisch haalbare model. Links voor individuele dieren; rechts voor de hele koppel van vifftien koeien

\begin{tabular}{|c|c|c|}
\hline Bijvoeding & Grasopname & Koegedrag \\
\hline Grasgroei & Bodem & Grasvoorraad \\
\hline
\end{tabular}




\section{Dagbesteding in de wei}

In de beweidingsproeven van Amazing Grazing zijn belangrijke gedragskenmerken van alle koeien continu gemeten. Zo krijgen we een nieuw beeld van het koegedrag in de wei.

\section{Gedrag in kaart met drie sensoren}

Alle koeien waren voorzien van drie sensoren. Ten eerste een Nedap pootsensor die vastlegt hoe vaak een koe gaat liggen en hoe lang ze staat of ligt. Staan betekent zowel stilstaan als lopen. Tot slot telt de pootsensor ook het aantal stappen. Ten tweede was elke koe voorzien van een Nedap halssensor die de vreettijd vastlegt. Ten slotte een sensor in het oor (Agis SensOor) die de herkauwtijd vastlegt. Hieronder zetten we de gedragskenmerken op een rij, gemiddeld voor de hele koppel over het hele weideseizoen. In Zegveld is met een gemengde koppel van Holsteins en Jerseys geweid. Voor de vergelijkbaarheid met Dairy Campus laten we

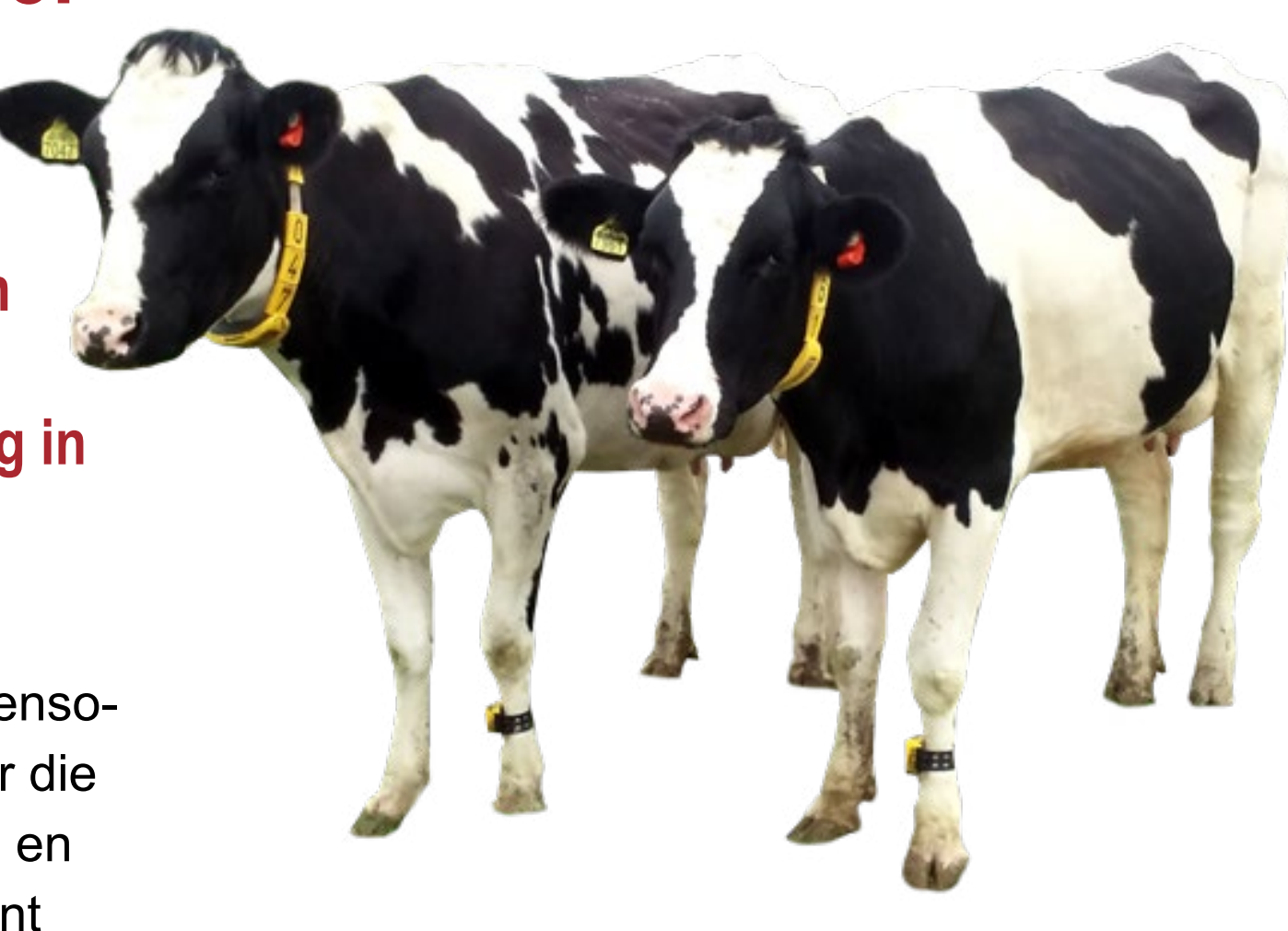

in de figuren alleen de resultaten van de Holsteins zien. Op Zegveld liepen de koeien meestal 's nachts in de weide, gemiddeld ruim twaalf uur per etmaal. Op Dairy Campus is overdag geweid, gedurende ruim zeven uur. Op Zegveld is in 2018 stripgrazen vervangen door roterend standweiden; daarom worden de resultaten voor Zegveld in 2016-2017 en 2018 apart weergegeven.

\section{Staan en liggen}

Op Dairy Campus stonden de koeien gemiddeld ongeveer vijf van de zeven uur. De overige twee uur brachten ze liggend door. In die statijd zetten ze ruim 16.000 stappen. Op Zegveld stonden de koeien een klein uur langer en zetten ze bijna 2.000 stappen meer. Over het algemeen waren er geen grote verschillen in sta- en ligtijd tussen de beweidingssystemen. Wel was het aantal stappen bij Kurzrasen duidelijk hoger dan bij stripgrazen of roterend standweiden.

De Jerseys brachten een groter deel van de dag staand door; ongeveer een uur langer dan de Holsteins. Bovendien zetten ze per dag ruim 6000 stappen meer dan de Holsteins.

$$
\text { Lees verder }
$$

\begin{tabular}{|c|c|c|}
\hline Bijvoeding & Grasopname & Koegedrag \\
\hline Grasgroei & Bodem & Grasvoorraad \\
\hline
\end{tabular}

- Sociale koeien

- Schatting dagelijkse grasopname in wei

- Dagbesteding in de wei

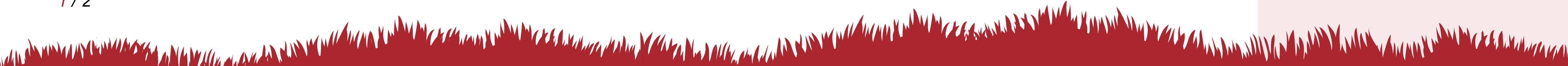


- Vreten - Herkauwen - Overig

Vreten en herkauwen

Op Dairy Campus waren de koeien gemiddeld vier uur aan het vreten, ruim $50 \%$ van de tijd in de weide. De herkauwtijd was daar gemiddeld anderhalf uur, ruim $20 \%$ van de weidetijd. Op Zegveld vraten de koeien 40 minuten langer, en herkauwden ze zelfs drie uur langer. In het Kurzrasen systeem waren de koeien langer aan het vreten dan in de andere beweidingssystemen. De herkauwtijd lijkt wat lager te zijn bij roterend standweiden, zowel op Zegveld als op Dairy Campus. De Jerseys waren ten opzichte van de Holsteins gemiddeld een half uur langer aan het vreten, maar 20 minuten korter aan het herkauwen.
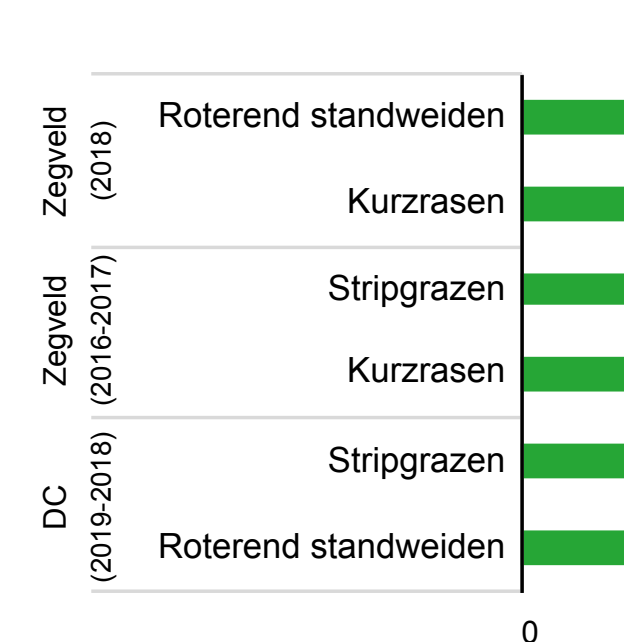

100

300

Tijd (minuten)

Gemiddelde tijd in de wei (minuten per koe per dag), besteed aan vreten of herkauwen. Het aandeel (\%) van deze activiteiten van de totale weidetijd staat in de balk weergegeven. Resultaten voor Holstein dieren. Dairy Campus $(D C)$ is overdag weiden, Zegveld is 's nachts weiden

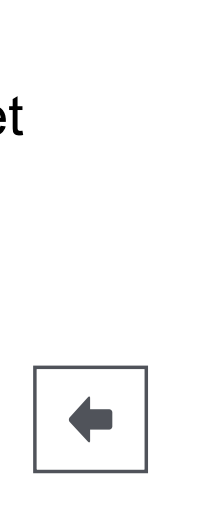

\section{Koegedrag}

- Sociale koeien

- Schatting dagelijkse grasopname in wei

- Dagbesteding in de wei

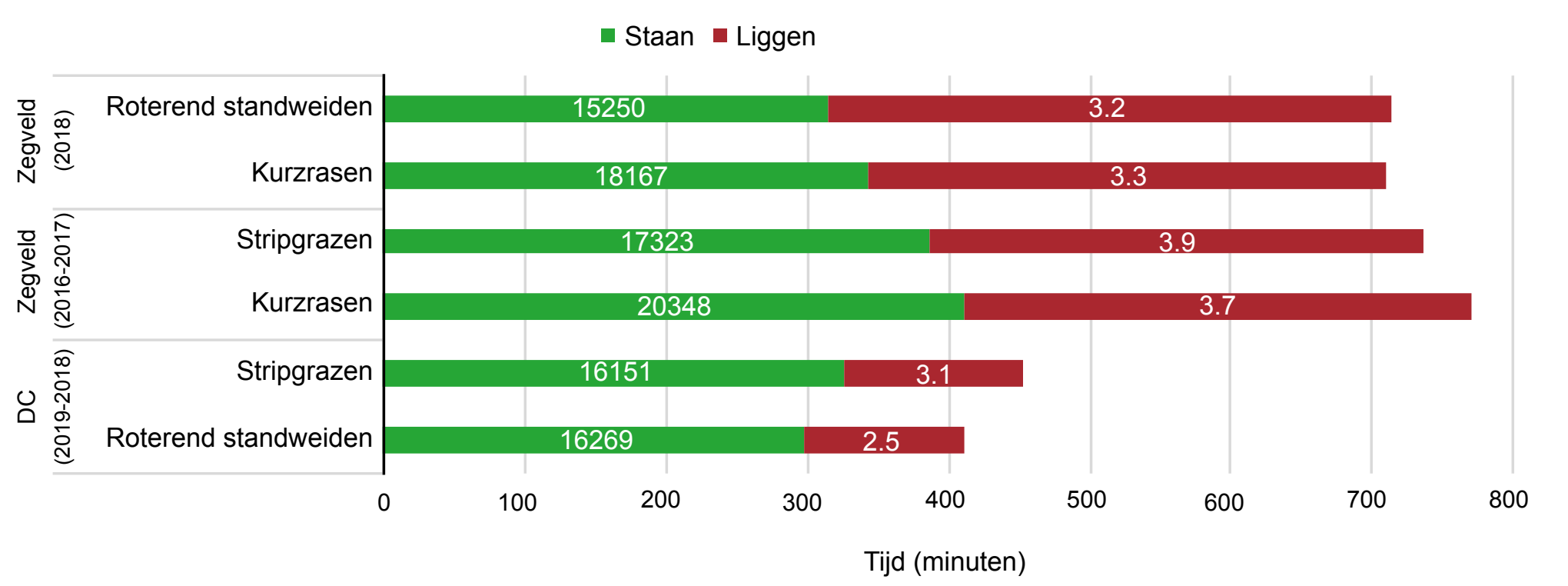

Gemiddelde tijd in de wei (minuten per koe per dag), besteed aan staan of liggen. Het getal in de groene balk is het aantal stappen per dag. Het getal in de rode balk is het aantal keren dat een koe gaat liggen en opstaan per dag. Resultaten voor Holstein dieren. Dairy Campus (DC) is overdag weiden, Zegveld is 's nachts weiden 


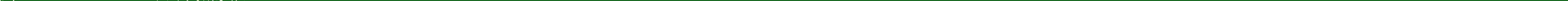




\section{Denken in platforms}

In modern graslandgebruik werken we met denkbeeldige platforms om op een flexibele manier onderscheid te maken tussen een groep percelen met hetzelfde gebruik; beweiden of maaien voor voederwinning.

\section{Flexibele fictieve platforms}

Nederlandse melkveebedrijven gebruiken grasland voor beweiding en voederwinning. Soms worden percelen uitsluitend gemaaid, maar meestal wordt hetzelfde perceel afwisselend beweid en gemaaid. Het aantal percelen dat nodig is voor beweiding varieert in de loop van het seizoen, onder andere door de wisselende grasgroei. Het graslandgebruik is makkelijker te plannen door de percelen, die op hetzelfde moment een gelijk gebruik hebben, toe te kennen aan een fictief weideof maaiplatform. Het gebruik van platforms is zeer flexibel en sluit aan bij alle voorkomende situaties. Percelen zitten niet vast in een platform, maar kunnen in de loop

$1 / 2$
Grasland

Beweidbaar

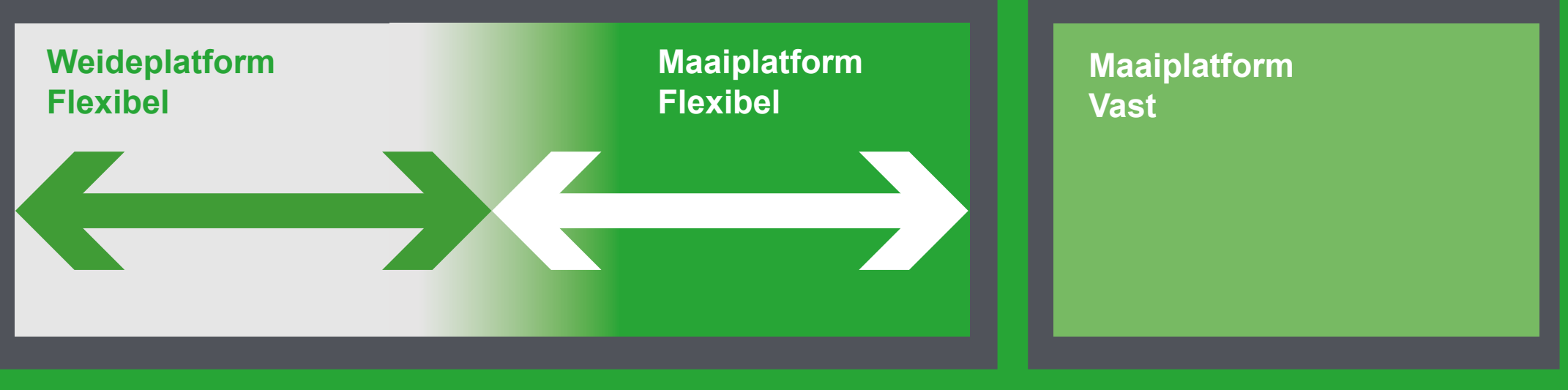

Fictieve flexibele platforms voor de planning van graslandgebruik

van het jaar heen en weer schuiven tussen de verschillende platforms.

\section{Weideplatform en maaiplatform}

Het weideplatform bevat alle percelen die in de planning voor beweiding meelopen; het maaiplatform bevat de percelen die gepland staan voor voederwinning. Tussen weideplatform en maaiplatform zijn percelen onderling te verplaatsen. De oppervlakte grasland die op een bepaald moment niet nodig is voor beweiding kun je naar het maaiplatform verplaatsen. Omgekeerd, wanneer ze weer nodig zijn voor beweiding kun je ze toevoegen aan het weideplatform. Percelen die, om welke reden dan ook, uitsluitend worden gemaaid zijn uiteraard vastgekoppeld aan het maaiplatform.

\section{Omweiden en standweiden}

Denken in platforms kan altijd, maar de exacte uitwerking verschilt tussen

$$
\text { Lees verder } \Rightarrow
$$

\section{Grasvoorraad}

- Denken in platforms

- Feedwedge voor omweiden - Planning van standweiden

- Maaivenster en maaiplatform

- Grasaanbod

- Mestflatten en grasaanbod

- Drone herkent weiderest

- Remote sensing meet grasvoorraad

- Grasopbrengst schatten 
omweiden en standweiden. Bij omweiden grazen de koeien het gras in één of enkele dagen af waarna ze naar een volgend perceel gaan. Het beweidingsplatform bevat dan alle percelen die in de planning voor beweiding meelopen. Bij standweiden grazen de koeien gedurende langere tijd op een vaste oppervlakte waarbij de dagelijkse bijgroei zo goed mogelijk in balans is met de dagelijkse opname. Het beweidingsplatform bevat dan uitsluitend de betreffende oppervlakte waar de koeien op dat moment grazen.

Voor beide systemen, omweiden en standweiden, geldt dat de percelen voor voederwinning aan het maaiplatform zijn toegewezen. Na de voederwinning is er echter een duidelijk onderscheid tussen beide systemen. In het geval van omweiden kunnen de vrijgekomen percelen direct in het beweidingsplatform meelopen in de planning. In het geval van standweiden 'parkeer' je een vrijgekomen maaiperceel eerst in een groeiplatform totdat het geschikt is om te weiden

\section{Tools}

In Amazing Grazing zijn verschillende hulpmiddelen voor graslandgebruik ontwikkeld en getest, die allemaal gebruik maken van platforms. De Feedwedge voor omweiden werkt met een weideplatform voor alle percelen die meelopen in de planning voor beweiding. De standweidentool heeft een grasvenster met het weideplatform voor de percelen waar de koeien op dat moment weiden en een perceelsvenster voor de percelen in het groeiplatform. Het maaivenster is de tool voor de planning van de percelen in het maaiplatform. Beide weidetools, de Feedwedge en de standweidentool, kun je koppelen aan het maaivenster.

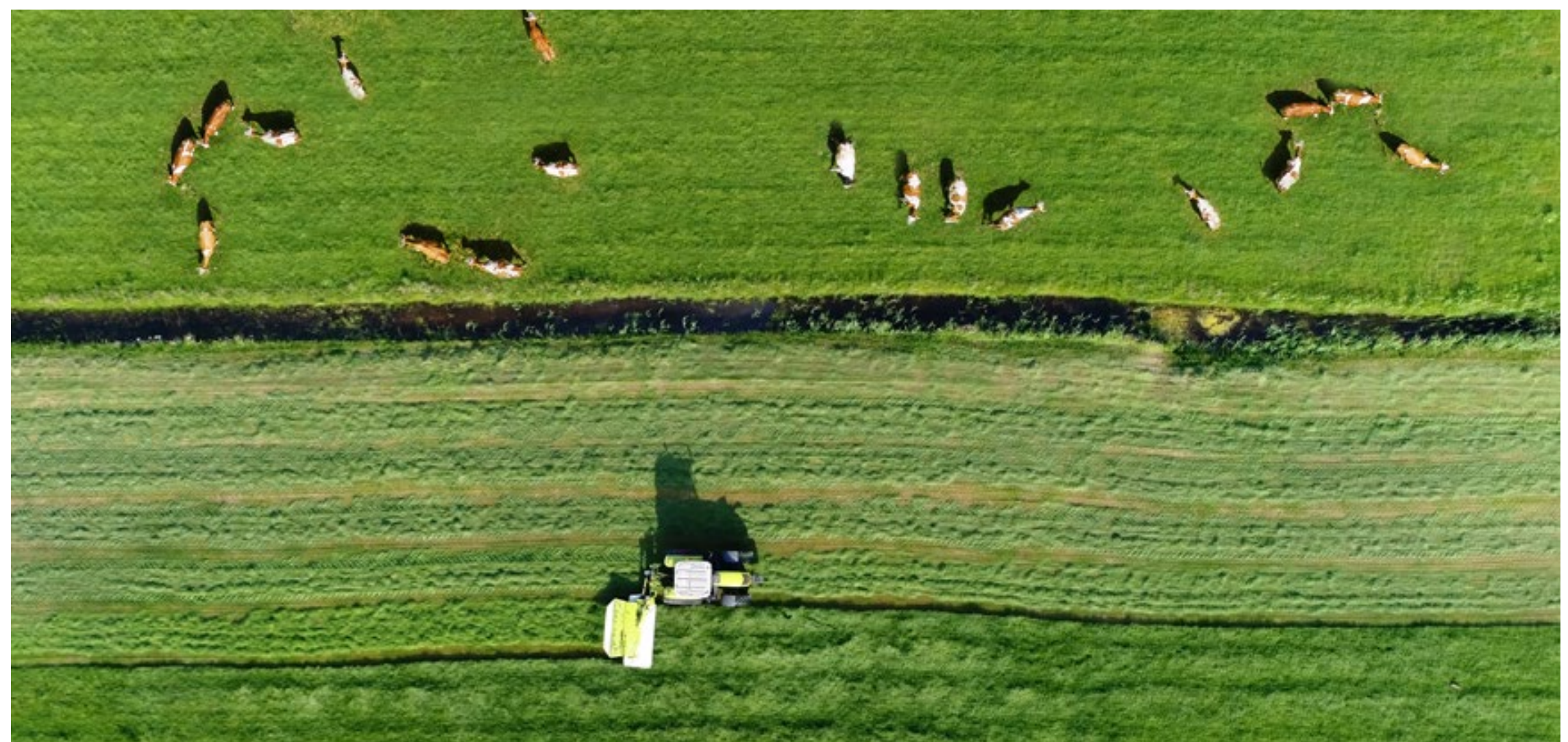

\section{Grasvoorraad}

- Denken in platforms

- Feedwedge voor omweiden

- Planning van standweiden

- Maaivenster en maaiplatform

- Grasaanbod

- Mestflatten en grasaanbod

- Drone herkent weiderest

- Remote sensing meet

grasvoorraad

- Grasopbrengst schatten

\begin{tabular}{|c|c|c|}
\hline Bijvoeding & Grasopname & Koegedrag \\
\hline Grasgroei & Bodem & Grasvoorraad \\
\hline
\end{tabular}




\section{Feedwedge voor omweiden}

De Feedwedge geeft in één plaatje een snel beeld van het huidige grasaanbod en de grasbehoefte voor beweiding. Vergelijken van het aanbod met de behoefte levert belangrijke informatie voor de planning van het graslandgebruik en de bijvoeding.

\section{Grasaanbod}

Het gebruik van de Feedwedge vraagt een wekelijks rondje over het grasland, de zogenaamde FarmWalk. Daarbij schat of meet je het grasaanbod op elk perceel. Nadat het grasaanbod is verzameld, rangschik je de percelen van hoog naar laag grasaanbod, uitgedrukt in $\mathrm{kg}$ droge stof per ha. Zo ontstaat een kolomdiagram, in de vorm van een zogenaamde 'wig', waarin het grasaanbod is uitgezet tegen de oppervlakte. De breedte van elke kolom geeft de oppervlakte van het perceel weer.

\section{Grasbehoefte}

De grasbehoefte is afhankelijk van de veebezetting en de gewenste grasopname. In de Feedwedge vertaal je de grasbehoefte in een getekende lijn over de kolommen. Het startpunt van de lijn, linksboven, is het gewenste grasaanbod bij inscharen ter hoogte van het perceel met het hoogste actuele grasaanbod. Het eindpunt, rechtsonder, is de gewenste uitschaaropbrengst ter hoogte van het laatste perceel van het weideplatform.

\section{Beoordelen en sturen}

De ingevulde Feedwedge geeft direct inzicht in het actuele grasaanbod in vergelijking tot de behoefte. Zo is duidelijk of er een tekort of overschot aan gras is, waar je de koeien kunt inscharen en welke percelen je eventueel kunt maaien. De grasgroei bepaalt of grasbehoefte en grasaan-

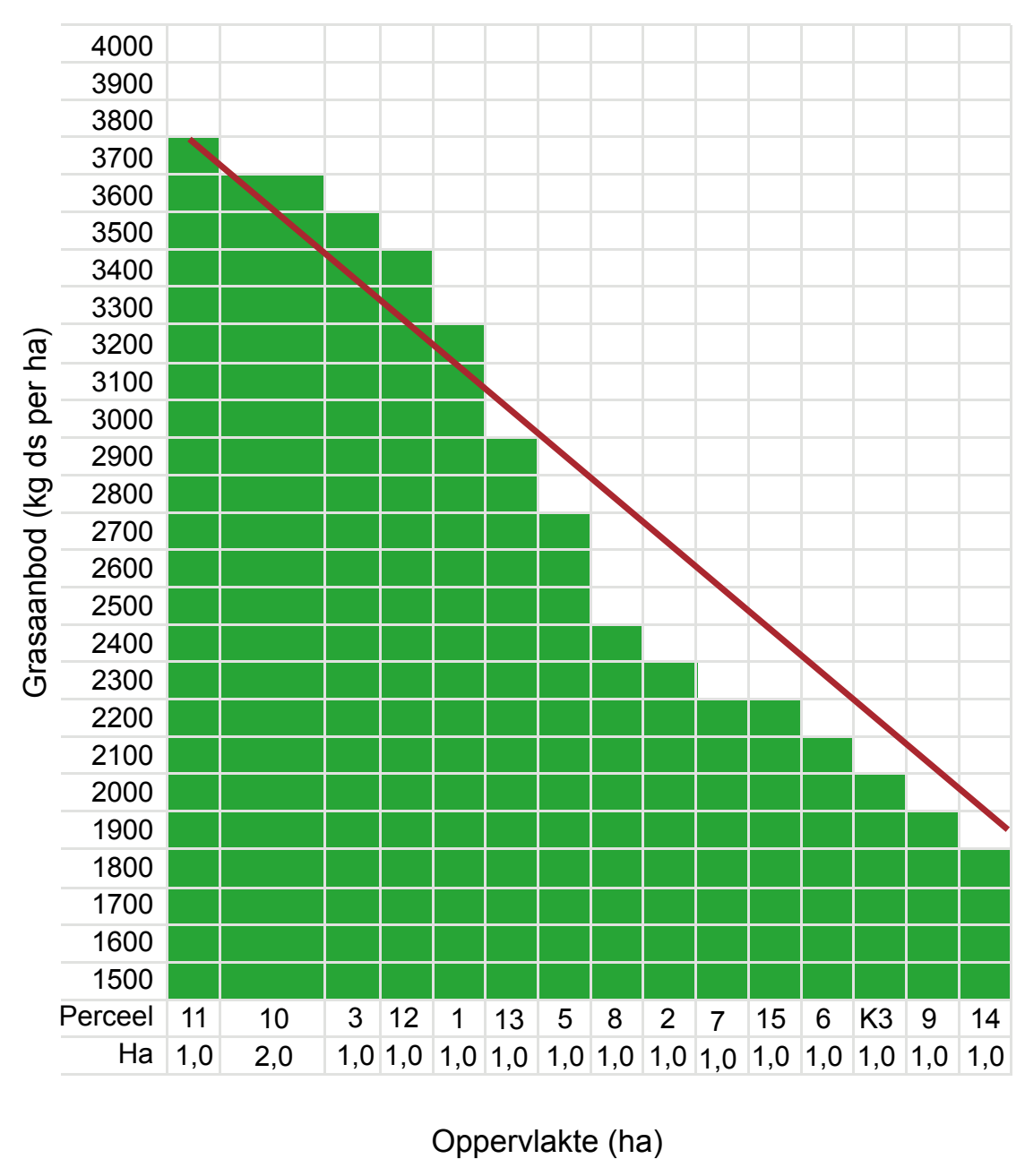

$$
\text { Oppervlakte (ha) }
$$

$$
\text { Grasaanbod }
$$$$
\text { Grasbehoefte }
$$

Voorbeeld van een ingevulde Feedwedge, waarin het grasaanbod is uitgezet tegen de oppervlakte van de beschikbare weidepercelen
- Denken in platforms

- Feedwedge voor omweiden - Planning van standweiden

- Maaivenster en maaiplatform

- Grasaanbod

- Mestflatten en grasaanbod

- Drone herkent weiderest

- Remote sensing meet grasvoorraad

- Grasopbrengst schatten

$$
\text { Lees verder }
$$

\begin{tabular}{|c|c|c|}
\hline \multicolumn{2}{|c|}{} \\
\hline \multicolumn{2}{|c|}{} \\
\hline Bijvoeding & Grasopname & Koegedrag \\
\hline \hline Grasgroei & Bodem & Grasvoorraad \\
\hline
\end{tabular}




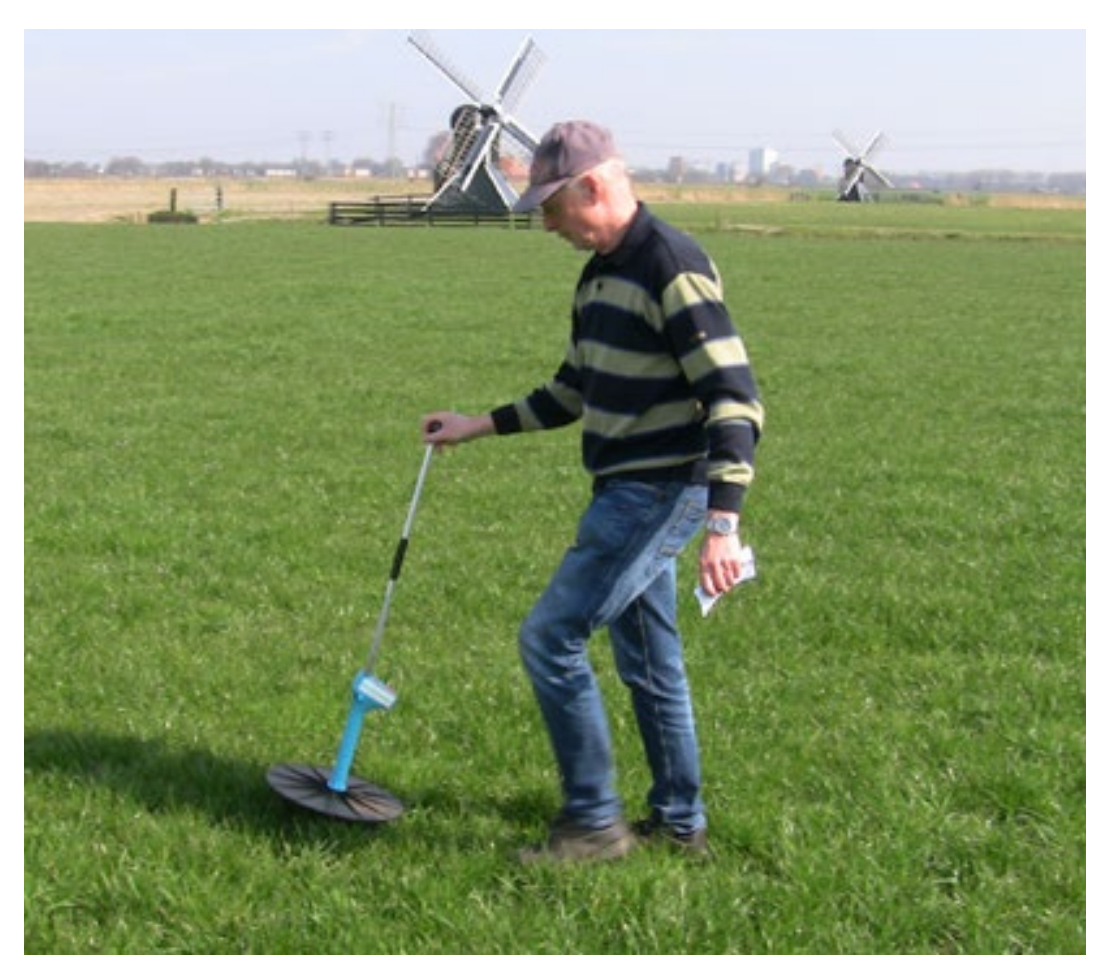

bod met elkaar in evenwicht zijn en stuurt eventuele aanpassingen in de oppervlakte van het weide- en maaiplatform. Is de grasgroei hoog dan is minder oppervlakte voor beweiding nodig en komt er ruimte om te maaien. Is de grasgroei laag, dan is er meer oppervlakte nodig voor beweiden en is de ruimte om te maaien beperkt.

Naast sturing op de oppervlakte van het weideplatform kun je ook de bijvoeding aanpassen om grasaanbod en grasbehoefte beter op elkaar af te stemmen.

\section{Grip op Gras}

De Feedwedge is beschikbaar op Akkerweb via de applicatie 'Grip op Gras'.

Tijdens de FarmWalk kun je de gras-

hoogtemetingen direct op je telefoon invoeren en koppelen aan de percelen. Grip op Gras vult automatisch de Feedwedge in wanneer is aangegeven welke percelen tot het weideplatform behoren. In Amazing Grazing is Grip op
Gras getest onder melkveehouders. De belangrijkste motivatie voor gebruik van de tool is de verbeterde graslandgebruiksplanning. De FarmWalk kost ongeveer anderhalf tot twee uur per week en de planning nog eens een half uur per week. Beginnende gebruikers, zonder ervaring met graslandplanning en grashoogtemetingen, vonden het gebruik van Grip op Gras lastig in het begin.

\section{Grasvoorraad}

- Denken in platforms

- Feedwedge voor omweiden

- Planning van standweiden

- Maaivenster en maaiplatform

- Grasaanbod

- Mestflatten en grasaanbod

- Drone herkent weiderest

- Remote sensing meet grasvoorraad

- Grasopbrengst schatten

\section{Verder lezen in rapporten}

\section{van Amazing Grazing}

- Stienezen et al., 2019. Beheer vers gras aanbod bij omweiden. Feedwedge en maaivenster; concepten, rekenregels en aanbevelingen ter verbetering.

Rapport in voorbereiding.

\begin{tabular}{|c|c|c|}
\hline \multicolumn{2}{|c|}{} \\
\hline \multicolumn{2}{|c|}{} \\
\hline \hline Bijvoeding & Grasopname & Koegedrag \\
\hline \hline Grasgroei & Bodem & Grasvoorraad \\
\hline
\end{tabular}




\section{Planning van standweiden}

Bij standweiden is het streven om de dagelijkse bijgroei van gras zo goed mogelijk af te stemmen op de grasopname van de koppel. De standweidentool helpt daarbij.

\section{Platforms bij standweiden}

Standweiden is een beweidingssysteem waarbij de koppel een aantal weken of maanden op hetzelfde weideplatform graast. Naast het weideplatform kun je bij standweiden meerdere platforms instellen waaronder het maaiplatform en het groeiplatform. Dit is afhankelijk van de oppervlakte beschikbaar grasland. Het weideplatform bevat percelen die in gebruik zijn voor het standweiden. Het maaiplatform bevat de percelen die bijgroeien tot een maaisnede, terwijl het groeiplatform de percelen bevat die zijn gemaaid en nu weer bijgroeien voor beweiding. Wanneer het gras op de percelen die het groeiplat- form vormen de gewenste grashoogte voor weiden heeft bereikt, gaan de koeien naar deze percelen en verschuift dus het weideplatform. En daarmee ook het groei- en maaiplatform.

\section{Grashoogte}

De streefwaarde voor de grashoogte is ongeveer $10 \mathrm{~cm}$, met een toegestane afwijking van 1 à $2 \mathrm{~cm}$. Tegen het einde van het weideseizoen, vanaf 1 september, is de streefwaarde ongeveer $8 \mathrm{~cm}$. Houd er rekening mee dat dit de grashoogte is inclusief de stoppel; dus gemeten vanaf de grond. Een constante grashoogte betekent dat de grasopname van de koeien gelijk moet zijn aan de bijgroei van het gras. Het principe van standweiden klinkt eenvoudig, maar omdat de grasgroei en de grasopname van de koeien niet constant zijn, is soms een ingreep nodig. Als het

\section{Standweiden}

De basis van standweiden is dat het koppel voor een langere periode op dezelfde oppervlakte grasland graast, het weideplatform. De bijgroei bepaalt het grasaanbod voor de koeien. Bij klassiek standweiden grazen de koeien het hele seizoen op dezelfde oppervlakte en blijft de grashoogte rond de $10 \mathrm{~cm}$. Kurzrasen is een vorm van klassiek standweiden waarbij de grashoogte op 4 à $5 \mathrm{~cm}$ blijft. Bij roterend standweiden is het weideplatform opgedeeld in 4 tot 6 percelen of strips. De koeien krijgen elke dag toegang tot een nieuw perceel of strip. Het in 2018 gelanceerde Nieuw Nederlands Weiden bouwt voort op dit principe van roterend standweiden in één of meerdere platforms.

- Denken in platforms

- Feedwedge voor omweiden - Planning van standweiden

- Maaivenster en maaiplatform

- Grasaanbod

- Mestflatten en grasaanbod

- Drone herkent weiderest

- Remote sensing meet grasvoorraad

- Grasopbrengst schatten

\begin{tabular}{|c|c|c|}
\hline Bijvoeding & Grasopname & Koegedrag \\
\hline Grasgroei & Bodem & Grasvoorraad \\
\hline
\end{tabular}


grasaanbod onderin het streeftraject komt te liggen, kun je de oppervlakte van het beweidingsplatform vergroten of de bijvoeding verhogen. Andersom, wanneer het grasaanbod bovenin het streeftraject komt te liggen, verklein je de oppervlakte van het beweidingsplatform of druk je de bijvoeding van de koeien.

\section{Grasvenster en perceelsvenster}

De standweidentool maakt twee overzichten die handig zijn voor de planning. Het grasvenster laat voor het beweidingsplatform het verloop van de grashoogte in de tijd zien. Bovendien geeft het een schatting van de te verwachten grashoogte in de komende week bij ongewijzigde omstandigheden. In een oogopslag is te zien hoever de grashoogte boven of onder de ingestelde grenzen ligt, nu en in de komende week. Het perceelsvenster geeft de actuele grashoogte van alle percelen in het beweidingsplatform en het groeiplatform.

Lees verder

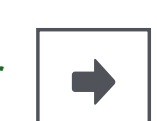

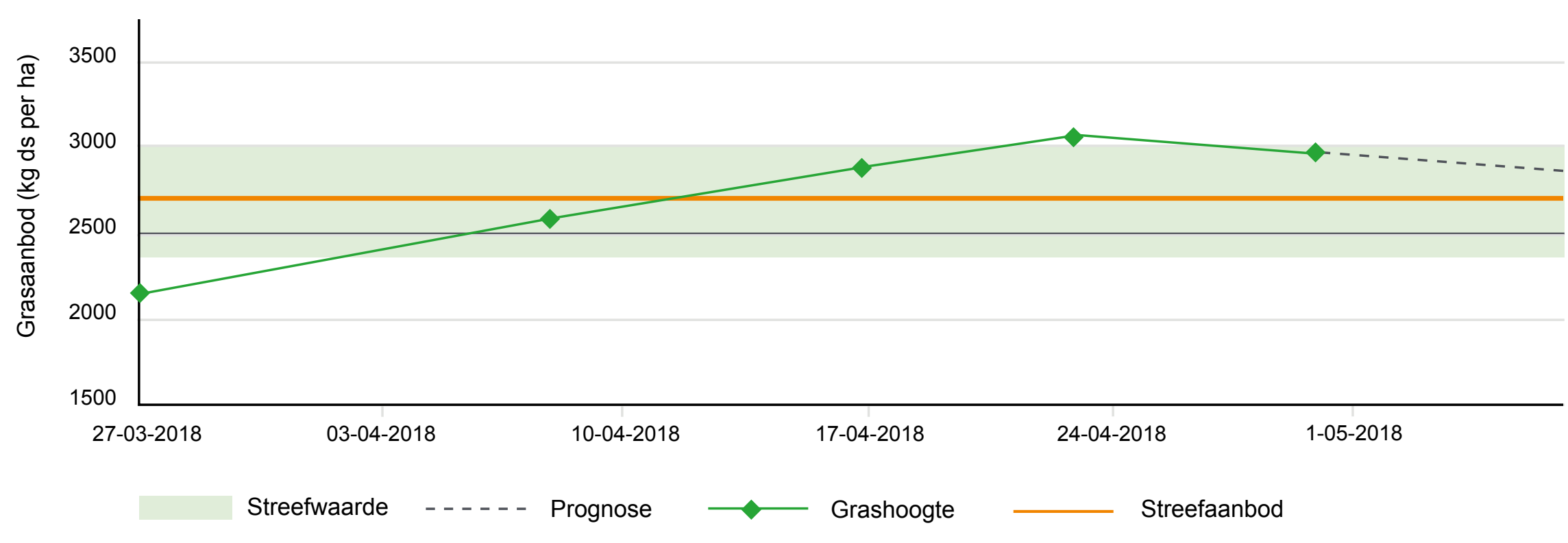

Voorbeeld van een grasvenster

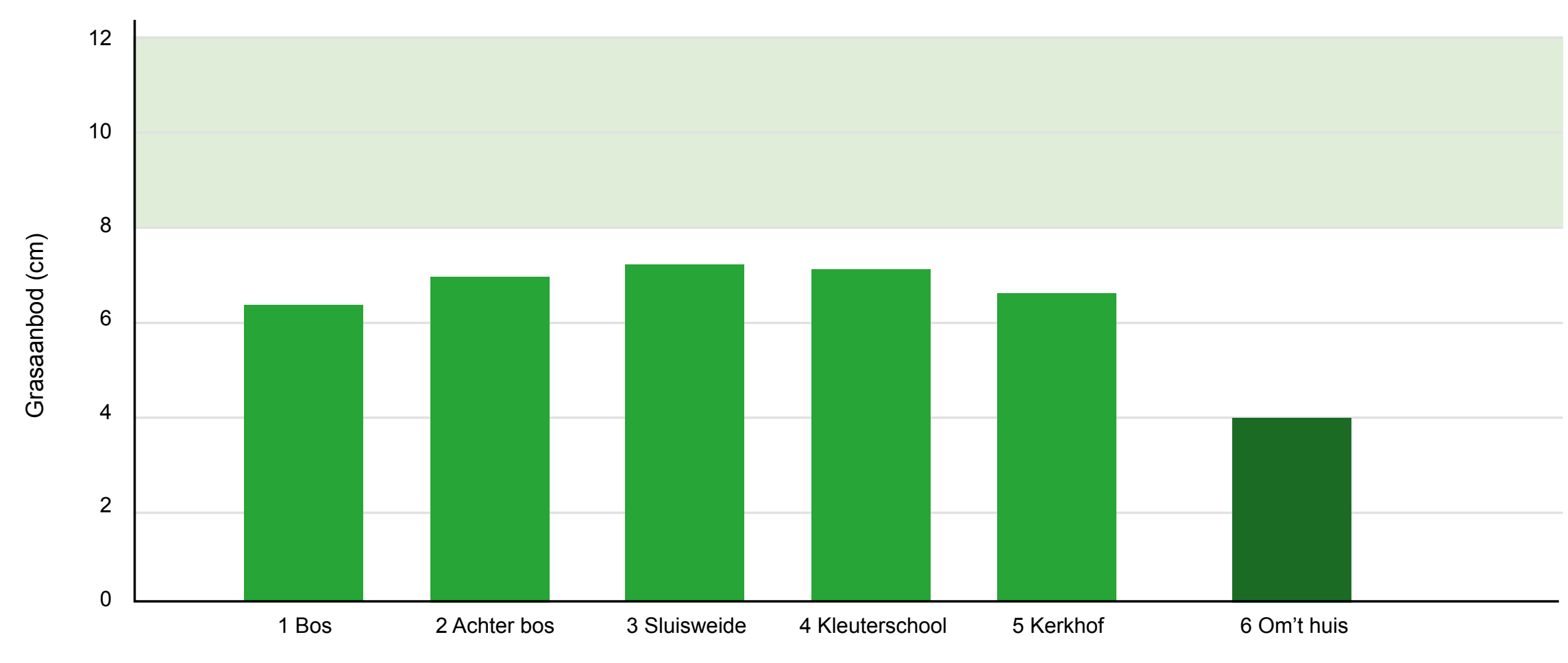
Streeftraject Grashoogte weideplatform Grashoogte groeiplatform

Voorbeeld van een perceelsvenster

\section{Grasvoorraad}

- Denken in platforms

- Feedwedge voor omweiden

- Planning van standweiden

- Maaivenster en maaiplatform

- Grasaanbod

- Mestflatten en grasaanbod

- Drone herkent weiderest

- Remote sensing meet grasvoorraad

- Grasopbrengst schatten

\begin{tabular}{|c|c|c|}
\hline \multicolumn{2}{|c|}{} \\
\hline \multicolumn{1}{|c|}{} \\
\hline Bijvoeding & Grasopname & Koegedrag \\
\hline Grasgroei & Bodem & Grasvoorraad \\
\hline
\end{tabular}




\section{Invoerkalender}

De invoerkalender is het hart van de standweidentool waar alle gegevens bij elkaar worden gebracht. Hierin geef je onder andere de minimale en maximale grashoogten tijdens beweiding aan. En, net als bij andere weidetools, voer je hier de resultaten in van de grashoogtemetingen tijdens de wekelijkse FarmWalk. In de kalender geef je ook aan tot welk platform een perceel behoort.

\section{Ervaringen}

Het concept van de standweidentool is door melkveehouders, adviseurs en onderzoekers samen ontwikkeld. De tool is als prototype in de vorm van een MS-excel spreadsheet beschikbaar met de naam 'Dashboard voor standweiden'. De tool is beter te gebruiken als je deze kunt voeden met de voorspelde grasgroei, de voeropname en het graslandgebruik.

\section{Download}

\section{Download hier het}

Dashboard voor standweiden.

- Denken in platforms

- Feedwedge voor omweiden

- Planning van standweiden

- Maaivenster en maaiplatform

- Grasaanbod

- Mestflatten en grasaanbod

- Drone herkent weiderest

- Remote sensing meet grasvoorraad

- Grasopbrengst schatten

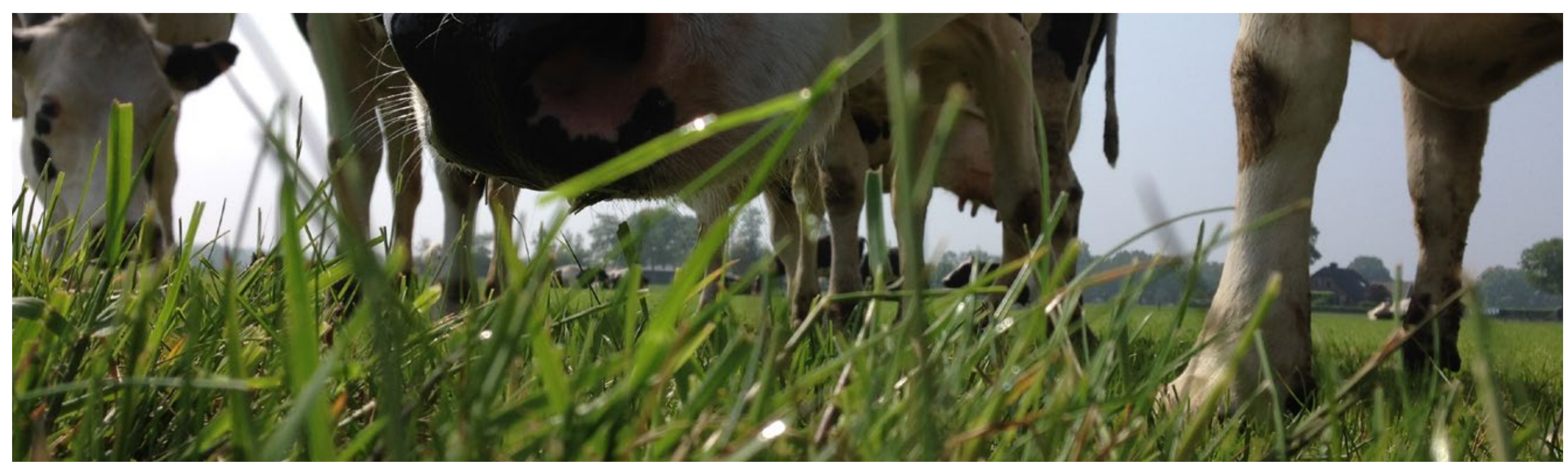




\section{Maaivenster en maaiplatform}

Weiden betekent in Nederland meestal een afwisselend gebruik van het grasland voor beweiding en voederwinning. Het maaivenster ondersteunt de planning van de voederwinning.

\section{Platforms en tools}

Voor de planning van de percelen in het weideplatform zijn de feedwedge voor omweiden en het Dashboard voor standweiden beschikbaar. De percelen bedoeld voor voederwinning horen thuis in het maaiplatform. Het maaivenster helpt met de planning van het juiste maaitijdstip.

\section{Maaivenster}

Het maaivenster toont voor elk perceel een overzicht van de actuele opbrengst, de streefopbrengst en de verwachte bijgroei. Je schat zelf de actuele opbrengst tijdens de FarmWalk en bepaalt ook zelf de

Lees verde

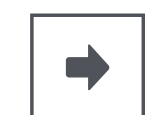

\section{Grip op Gras}

Het maaivenster is beschikbaar op Akkerweb via de applicatie 'Grip op Gras'. Tijdens de FarmWalk kun je de grashoogtemetingen direct op je telefoon invoeren en koppelen aan de percelen. Grip op Gras vult automatisch het maaivenster in voor de percelen die tot het maaiplatform behoren.
Voor de percelen in het maaivenster berekent Grip op Gras de actuele opbrengst en de verwachte bijgroei, en telt deze op tot de verwachte opbrengst. Verschillende kleuren attenderen je op hoever de verwachte opbrengst nog is verwijderd van de streefopbrengst of wellicht al hoger is.

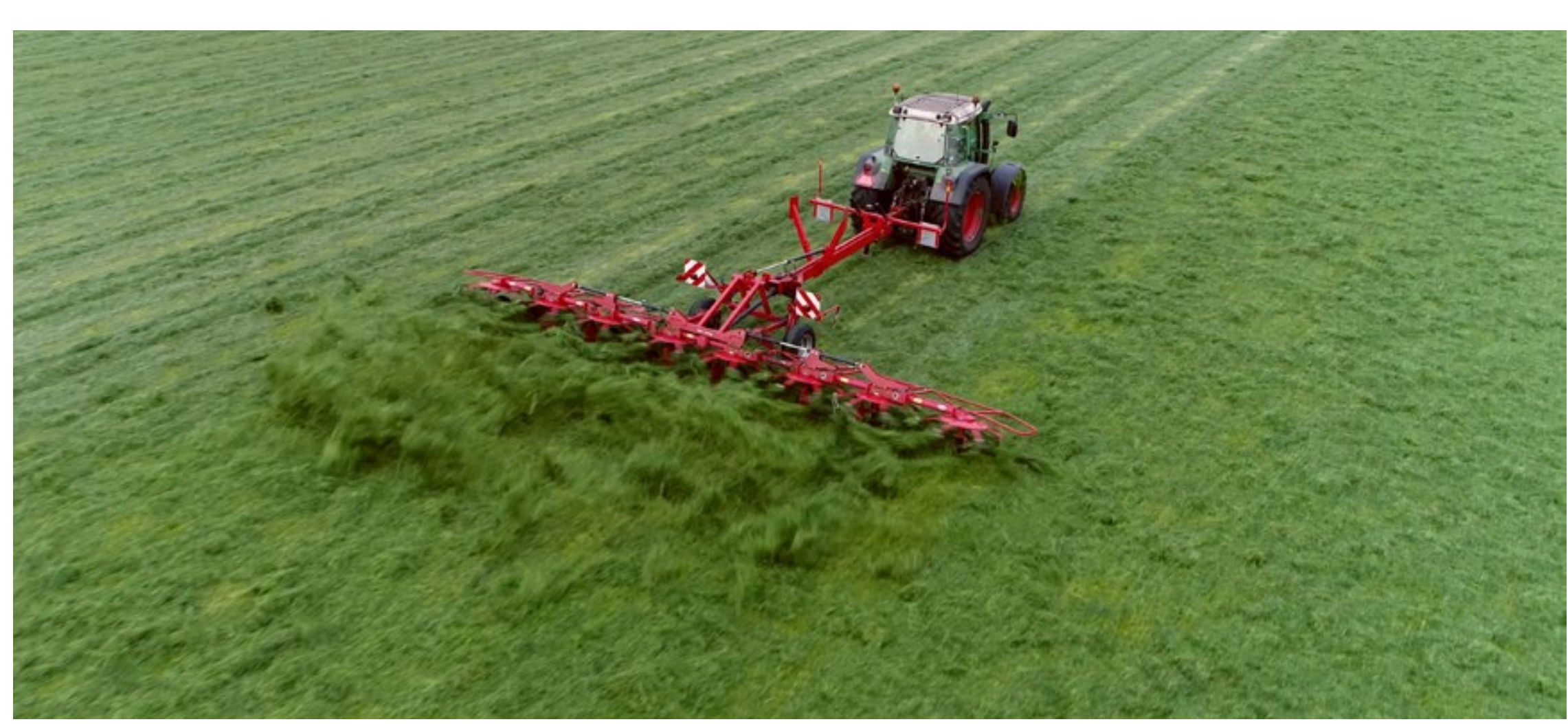

\section{Grasvoorraad}

Denken in platforms

- Feedwedge voor omweiden

- Planning van standweiden

- Maaivenster en maaiplatform

- Grasaanbod

- Mestflatten en grasaanbod

- Drone herkent weiderest

- Remote sensing meet

grasvoorraad

- Grasopbrengst schatten 
gewenste streefopbrengst. De verwachte bijgroei is gebaseerd op het aantal dagen waarop je vooruit wil kijken en de verwachte grasgroei per dag. De verwachte grasgroei is afgeleid van de groei in een gemiddeld jaar en is afhankelijk van het moment in het groeiseizoen en de actuele opbrengst.

\section{Maaitijdstip}

Het verschil tussen streefopbrengst en actuele opbrengst geeft aan hoe lang het nog duurt voordat de streefopbrengst is bereikt. Dit verschil wordt zowel berekend in $\mathrm{kg}$ droge stof per ha als in verwachte groeidagen. De veehouder krijgt hiermee inzicht in de speelruimte die hij heeft om de streefopbrengst te realiseren.

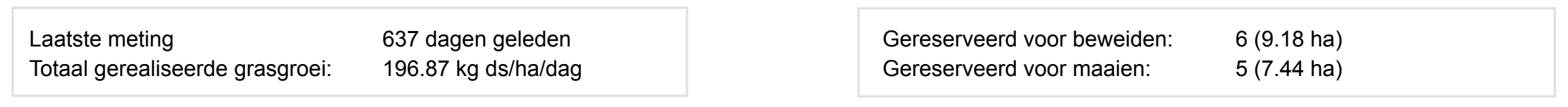

Laat zien van: $\quad 13$ juni

Bijgroei voor: 7 dagen

Afwijking streefopbrengst: $500 \mathrm{~kg}$ ds/ha

Gerealiseerde grasgroei: $183.59 \mathrm{~kg} \mathrm{ds} / \mathrm{h} / \mathrm{dag}$

Streef Verwachte

$\begin{array}{lrr} & \begin{array}{r}\text { opbrengst } \\ \text { Field 12 }\end{array} & \text { grasg } \\ \text { Field 10 } & 4500 \\ \text { Field 4 } & 4300 \\ \text { Field 3 } & 4000 & 1087 \\ \text { Field 1 } & 4500 & 1087\end{array}$

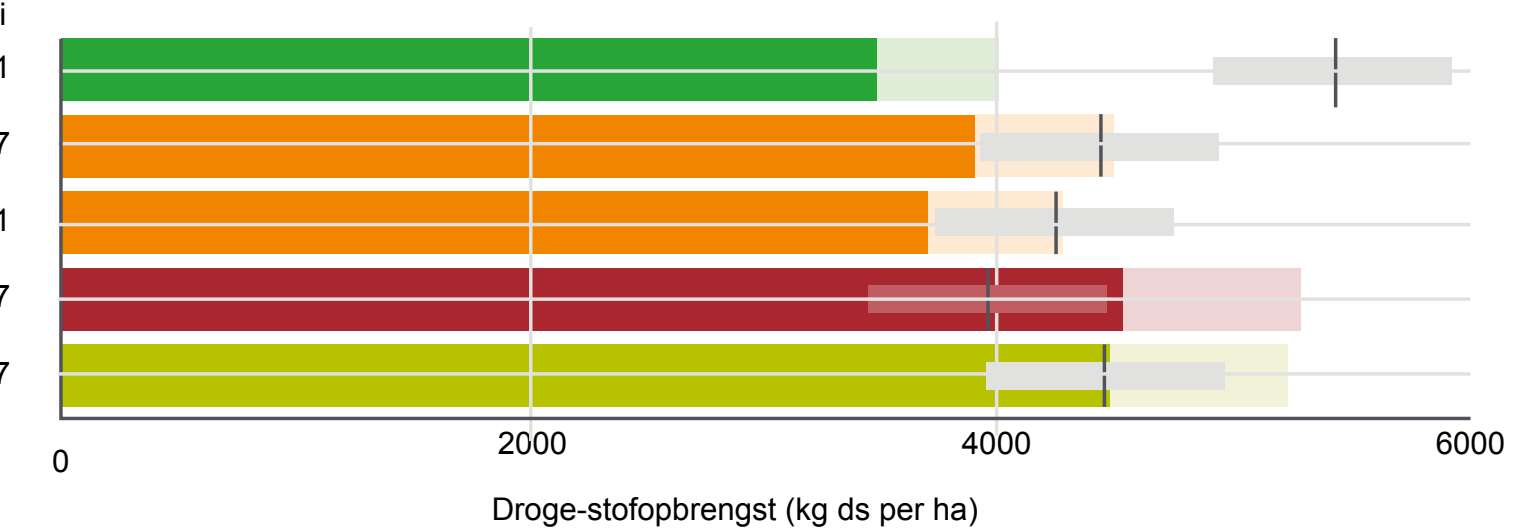

Voorbeeld van een maaivenster

\section{Grasvoorraad}

- Denken in platforms

- Feedwedge voor omweiden

- Planning van standweiden

- Maaivenster en maaiplatform

- Grasaanbod

- Mestflatten en grasaanbod

- Drone herkent weiderest

- Remote sensing meet grasvoorraad

- Grasopbrengst schatten

\section{$\leftarrow \quad$ Verder lezen in rapporten}

\section{van Amazing Grazing}

- Stienezen et al., 2019. Beheer vers gras aanbod bij omweiden. Feedwedge en maaivenster; concepten, rekenregels en aanbevelingen ter verbetering. Rapport in voorbereiding.
- Stienezen et al., 2018. Amazing Grazing: feed wedge and cutting window for grazing systems with high levels of supplementation. Grassland Science in Europe, 23.

\begin{tabular}{|c|c|c|}
\hline \multicolumn{2}{|c|}{} \\
\hline \multicolumn{2}{|c|}{} \\
\hline Bijvoeding & Grasopname & Koegedrag \\
\hline \hline Grasgroei & Bodem & Grasvoorraad \\
\hline
\end{tabular}




\section{Grasaanbod}

Het grasaanbod bij beweiding is de hoeveelheid gras die op het perceel staat op het moment van inscharen. Het grasaanbod wordt in de praktijk weergegeven als grashoogte of als hoeveelheid droge stof per ha, gemeten vanaf de grond.

\section{Grashoogte meten}

Het grasaanbod kan op verschillende manieren worden ingeschat. Heel eenvoudig door een visuele schatting van de grashoogte of beter: door de grashoogte te meten. Gebruik de wekelijkse FarmWalk om de grashoogte te meten en het aanbod te berekenen. Vanwege de variatie in een perceel zijn minimaal 30 willekeurige meetpunten per perceel nodig. Bij metingen in een weiderest is het aan te raden om 40 tot 50 metingen per perceel uit te voeren, vanwege de extra variatie in weideresten. Loop in een $\mathrm{W}$ - of $\mathrm{V}$-vorm door het perceel.

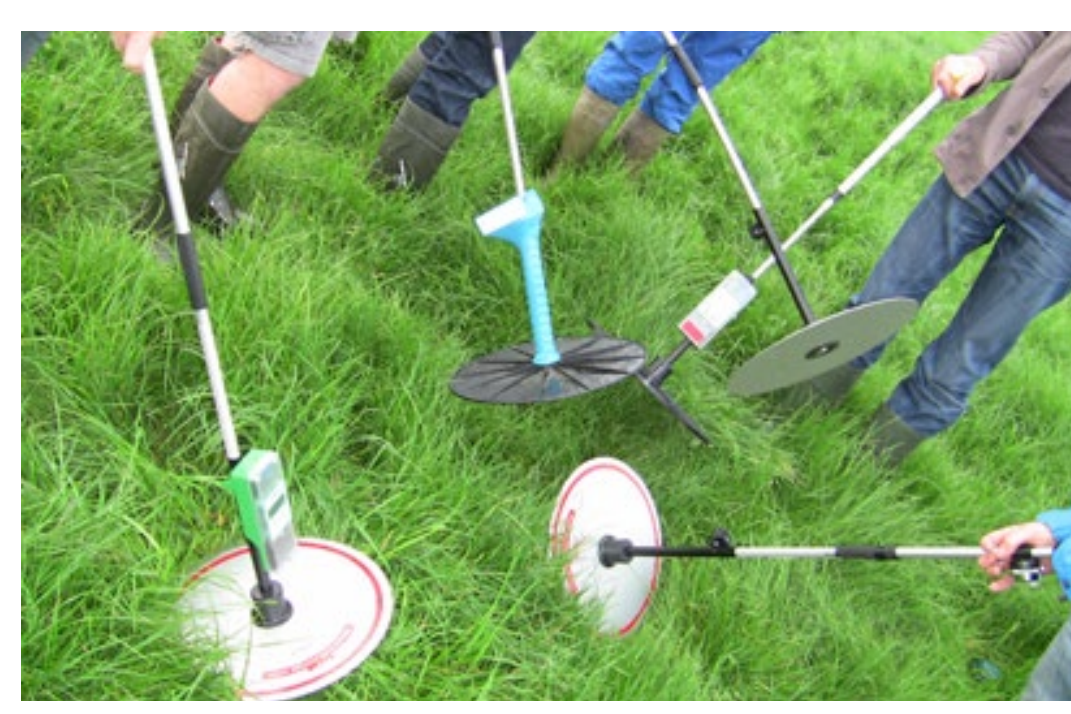

Van grashoogte naar droge stof

Momenteel zijn in Nederland twee soorten grashoogtemeters in gebruik. Dat zijn de oude bekenden met een grote lichte tempexschijf. De wat nieuwere modellen hebben een wat kleinere zwaardere schijf van kunststof of metaal. Het onderscheid is belangrijk omdat beide typen een eigen omrekening hebben van grashoogte naar hoeveelheid droge stof.

Bruto aanbod $\mathbf{=}$ netto aanbod + stoppel Bij beweiding maken we voor de bovengrondse delen van de grasplant, het 'bruto aanbod', onderscheid tussen een deel dat afgegraasd wordt, het 'netto aanbod', en het deel dat niet afgegraasd wordt, de 'rest' of 'stoppel'. Dit kan tot verwarring leiden, omdat in het verleden meestal netto aanbod is gebruikt, terwijl tegenwoordig meestal bruto aanbod wordt gebruikt. Ter illustratie: in een stoppel van $5,5 \mathrm{~cm}$ zit ongeveer $2000 \mathrm{~kg}$ droge stof per ha. $\mathrm{Bij}$ een streefwaarde van $1700 \mathrm{~kg}$ droge stof per ha netto aanbod, is het bruto aanbod voor inscharen dan $3700 \mathrm{~kg}$ droge stof per ha.

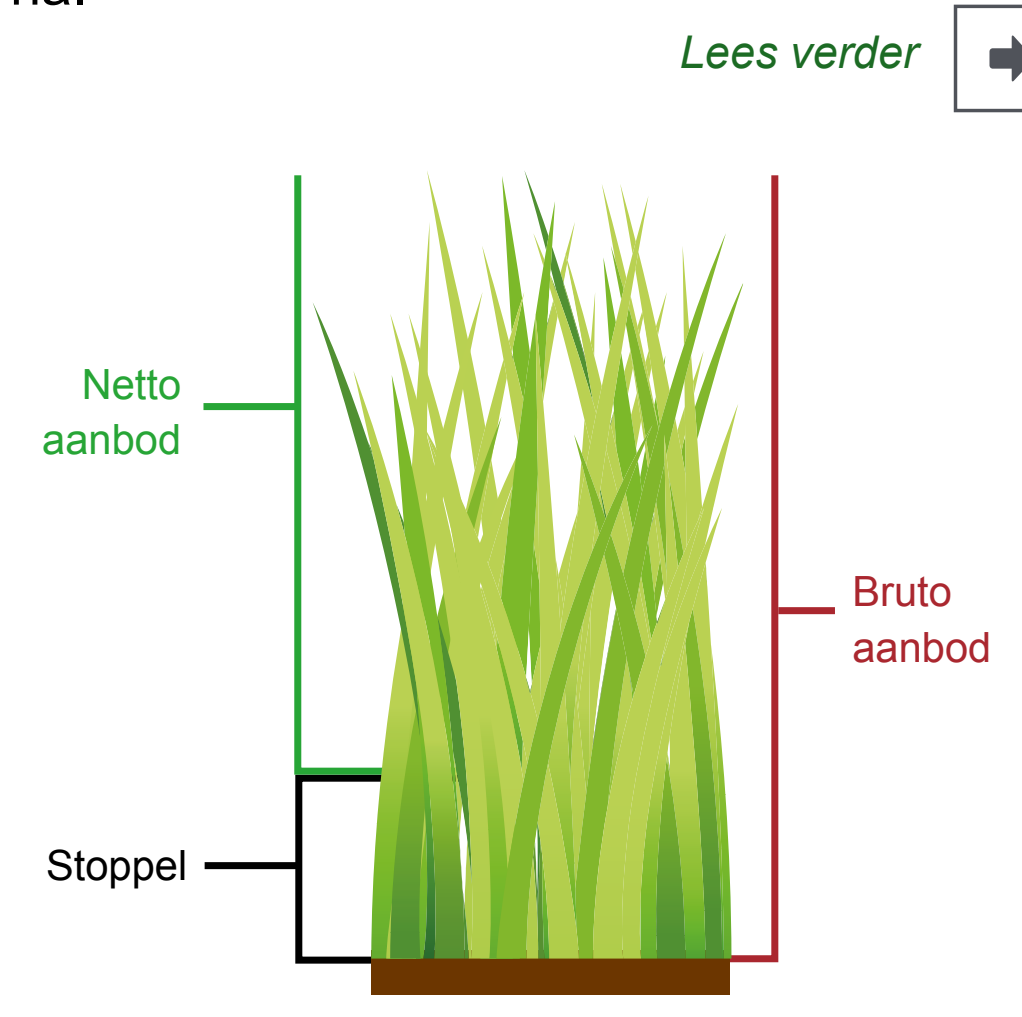

\section{Grasvoorraad}

- Denken in platforms

- Feedwedge voor omweiden - Planning van standweiden

- Maaivenster en maaiplatform

- Grasaanbod

- Mestflatten en grasaanbod

- Drone herkent weiderest

- Remote sensing meet grasvoorraad

- Grasopbrengst schatten 
Omrekening van grashoogte naar hoeveelheid droge stof. Bruto aanbod, gemeten vanaf de grond, en netto aanbod bij een stoppel van 3,5 of $7 \mathrm{~cm}$

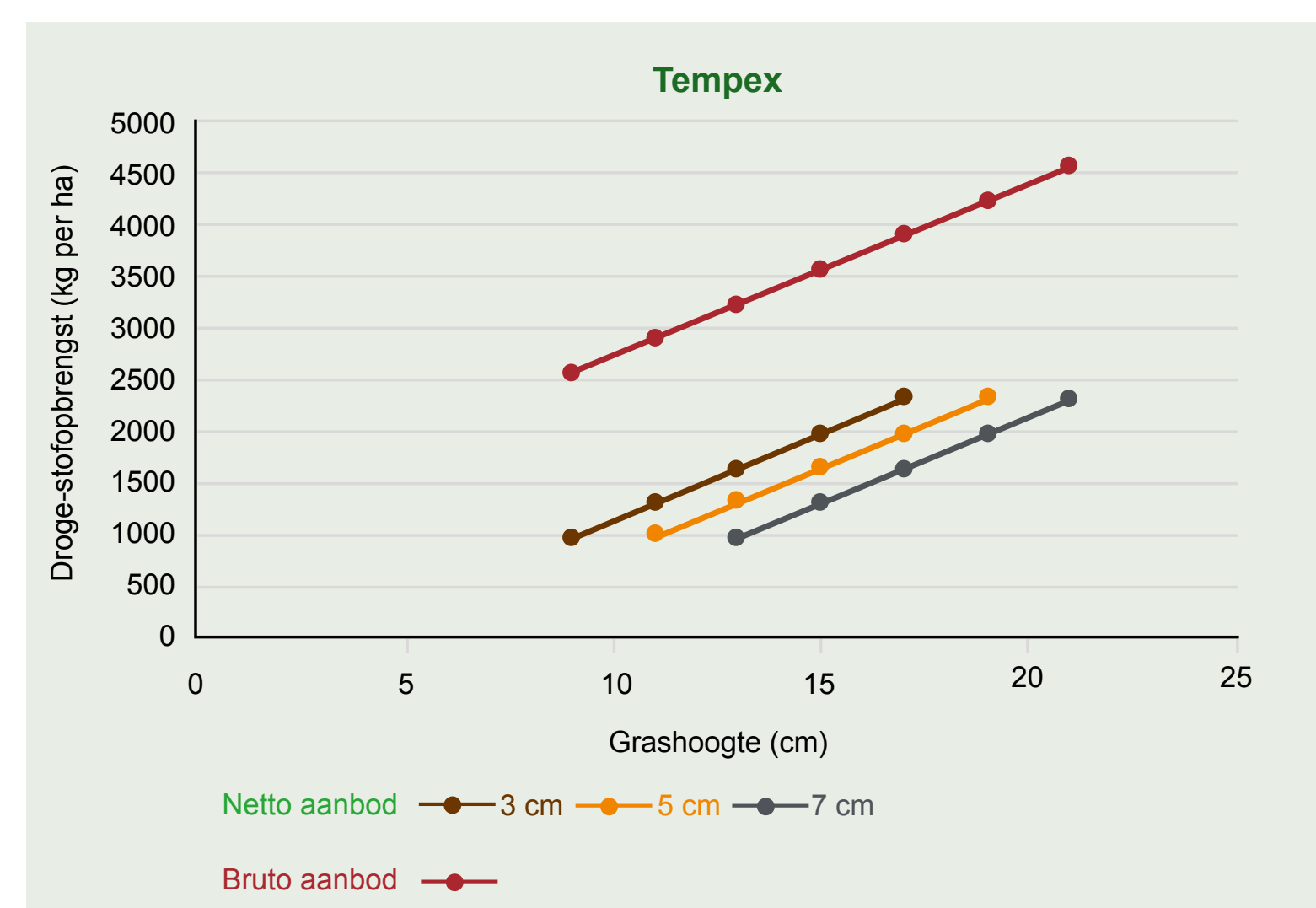

Omrekening van grashoogte naar hoeveelheid droge stof

bij tempex schijven

Bovengrondse hoeveelheid gras [kg ds per ha] $=1098+164$ * grashoogte [cm]

De formule voor de lichtere tempex schijven is nieuw. Voorheen werd de omrekening van grashoogte naar grasaanbod in $\mathrm{kg}$ droge stof per ha gedaan

voor het grasaanbod boven een stoppel van $5 \mathrm{~cm}$

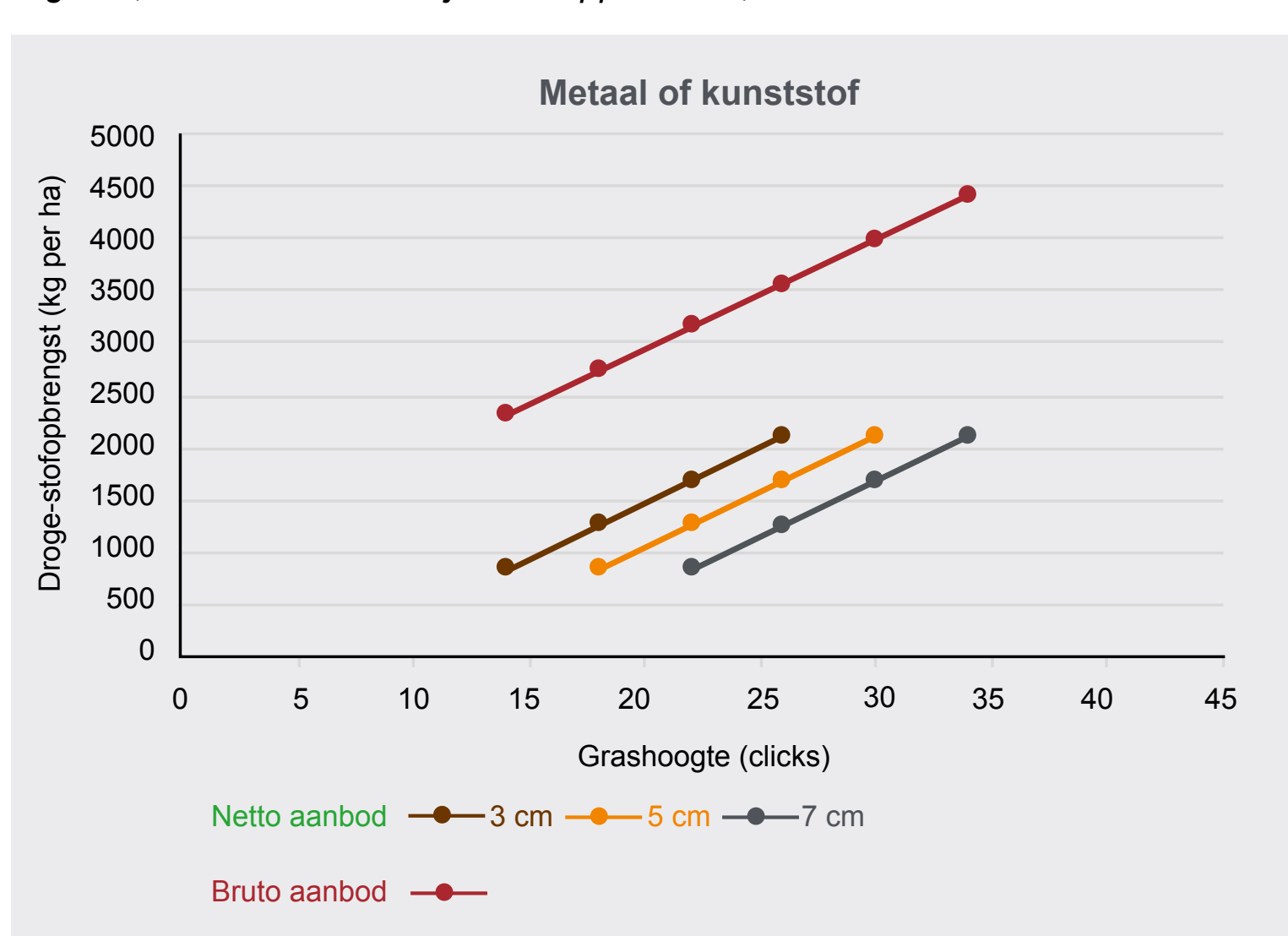

Omrekening van grashoogte naar hoeveelheid droge stof

bij metalen en kunststof schijven

Bovengrondse hoeveelheid gras [kg ds per ha] = $845+105{ }^{*}$ clicks [n]

Deze typen grashoogtemeters werken met clicks in plaats van centimeters
- Denken in platforms

- Feedwedge voor omweiden

- Planning van standweiden

- Maaivenster en maaiplatform

- Grasaanbod

- Mestflatten en grasaanbod

- Drone herkent weiderest

- Remote sensing meet

grasvoorraad

- Grasopbrengst schatten 


\section{Mestflatten en grasaanbod}

Beweiden leidt vrijwel altijd tot bosvorming, restanten gras die koeien niet opvreten. Bossen horen niet bij het grasaanbod en daar moet je rekening mee houden.

\section{Bevuilde oppervlakte}

Koeien zijn kieskeurig. Als gras niet lekker ruikt of smaakt door bevuiling met mest laten ze het gras meestal links liggen. Een koe laat ongeveer vijf mestflatten achter bij acht uur beweiding. Elke mestflat in de wei bedekt ongeveer 6 tot $7 \mathrm{dm}^{2}$ gras. Koeien mijden het gras rondom mestflatten minimaal een maand lang. De bevuilde oppervlakte neemt in de loop van het seizoen toe. Dit hangt uiteindelijk af van de beweidingsfrequentie, beweidingsduur en veebezetting.

\section{Grasaanbod}

Het netto grasaanbod voor een beweiding is het product van de aangeboden oppervlakte en de grashoogte boven de stoppel.

$1 / 2$

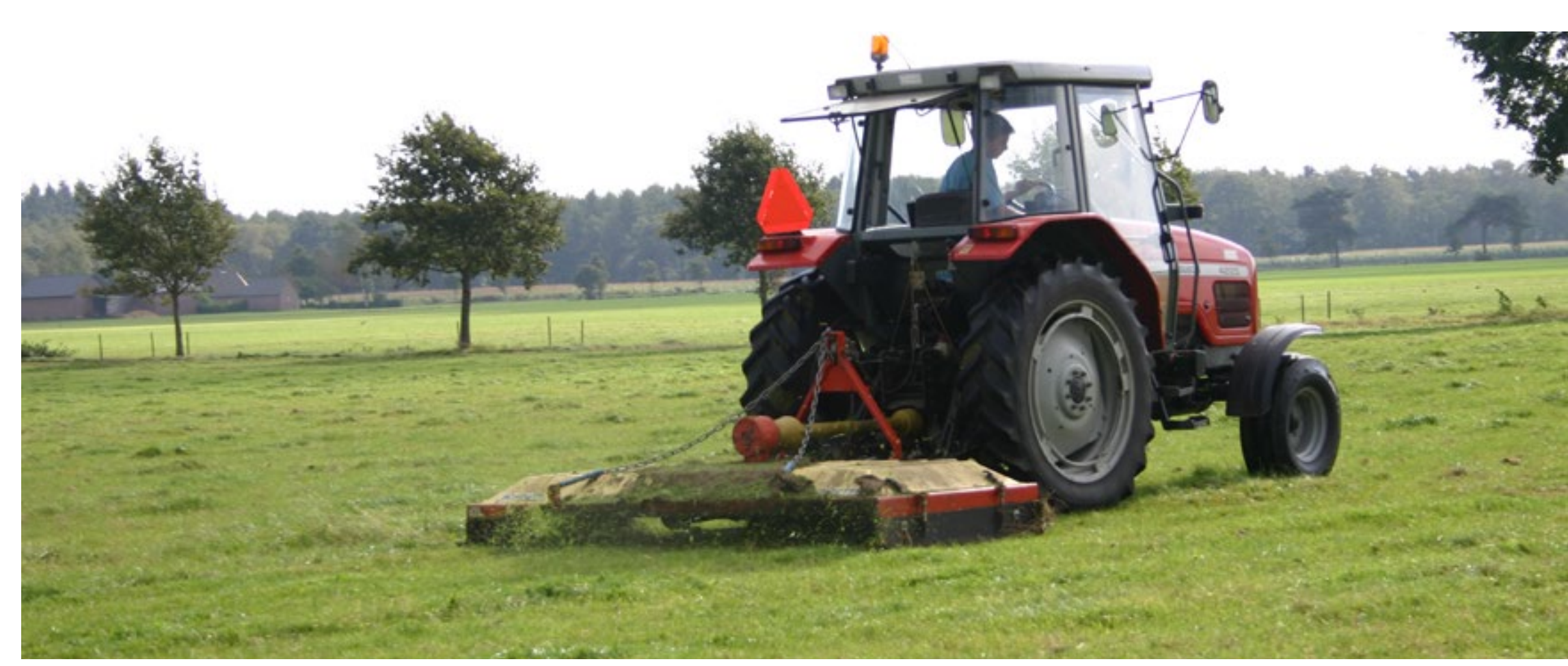

Een juiste inschatting van het aanbod is belangrijk voor een hoge grasopname met lage verliezen. Als je geen rekening houdt met de lagere grasopname rondom de bossen overschat je het grasaanbod. De gevolgen van overschatting van het grasaanbod zijn afhankelijk van het beweidingssysteem. In een systeem met een hogere beoogde reststoppel grazen de koeien het gras dieper af en laten een kortere stoppel achter dan de bedoeling was. Vanuit de kortere stoppel verloopt de hergroei trager en is het perceel later klaar voor de volgende ronde. In een systeem met een kortere beoogde reststoppel leidt de overschatting tot een lagere grasopname en zal de melkproductie dalen.

\section{Correctie op aanbod}

In Amazing Grazing is de weide-oppervlakte bedekt met bossen gemeten in de beweidingssystemen op Dairy Campus.

$$
\text { Lees verder }
$$

Grasvoorraad

- Denken in platforms

- Feedwedge voor omweiden - Planning van standweiden - Maaivenster en maaiplatform - Grasaanbod

- Mestflatten en grasaanbod - Drone herkent weiderest

- Remote sensing meet grasvoorraad

- Grasopbrengst schatten 
Dit is bepaald door met de grashoogtemeter in een $\mathrm{W}$-vorm door het veld te lopen en te tellen hoeveel van de metingen in een bos terecht kwam. De bevuilde oppervlakte in veldjes na beweiding nam toe van ongeveer $20 \%$ eind mei, tot zo'n $40 \%$ in juli en augustus. De bevuilde oppervlakte kun je aftrekken van de aangeboden oppervlakte om het grasaanbod correct in te schatten. Er was geen verschil tussen roterend standweiden en stripgrazen.
Met een bossenmaaier (bloten) verwijder je weliswaar de oude grasstengels, maar de geur van de mestflatten blijft aanwezig. Direct slepen na weidegang en spoelen met een beperkte watergift helpt wel om mestflatten sneller te laten verdwijnen. Het beste hulpmiddel is een maaisnede inplannen; daarna ben je wel weer zes weken verder.

\section{Grasvoorraad}

Verder lezen in rapporten van Amazing Grazing

- Klootwijk, C. W., Holshof, G., de Boer, I. J., Van den Pol-Van Dasselaar, A., Engel, B., \& Van Middelaar, C. E. (2019). Correcting fresh grass allowance for rejected patches due to excreta in intensive grazing systems for dairy cows. Journal of dairy science, 102(11), 10451-10459.
- Denken in platforms

- Feedwedge voor omweiden - Planning van standweiden - Maaivenster en maaiplatform - Grasaanbod

- Mestflatten en grasaanbod

- Drone herkent weiderest

- Remote sensing meet grasvoorraad

- Grasopbrengst schatten

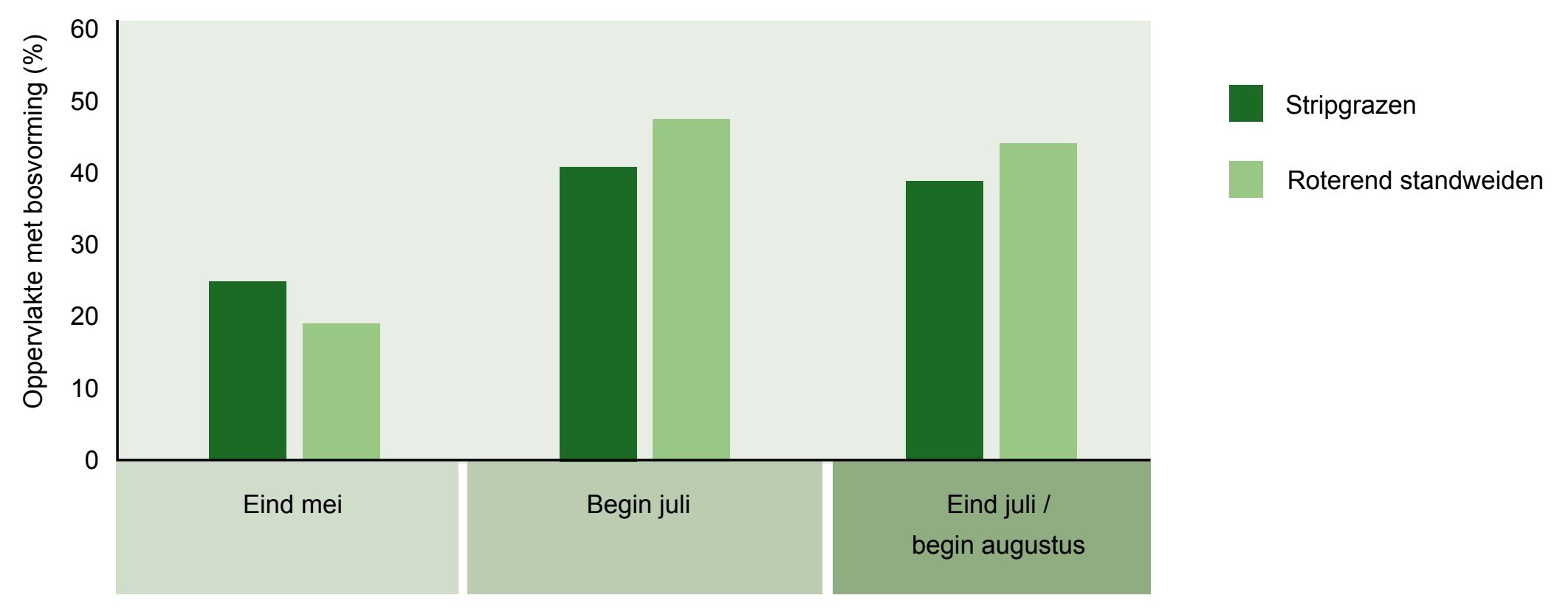

Oppervlakte (\%) met bosvorming in twee beweidingssystemen (7,5 koe per ha) op Dairy Campus (2016 en 2017)

\begin{tabular}{|c|c|c|}
\hline Bijvoeding & Grasopname & Koegedrag \\
\hline \hline Grasgroei & Bodem & Grasvoorraad \\
\hline
\end{tabular}




\section{Drone herkent weiderest}

Beweiden leidt vrijwel altijd tot bosvorming, restanten gras die koeien niet opvreten. Dronebeelden kunnen weideresten herkennen. Dat helpt om het werkelijke grasaanbod beter in te schatten.

\section{Weiderest is geen grasaanbod} Koeien mijden gras rondom mestflatten minimaal een maand lang. Indien je geen rekening houdt met de lagere grasopname rondom de bevuilde oppervlakte, overschat je het grasaanbod. Maar hoe kun je snel en eenvoudig de hoeveelheid weiderest schatten? Op Dairy Campus is een methode getest om met dronebeelden weideresten automatisch te herkennen. Dat gebeurt in twee stappen: ten eerste het schatten van de grashoogten en ten tweede, de relatief moeilijke stap, het selecteren van de weideresten.

\section{Grashoogte met NDVI}

De drone is uitgerust met een multispec- trale camera die onder andere opnames maakt van rood en nabij-infrarood licht dat vanaf het grasgewas wordt weerkaatst. De verhouding tussen rode en nabij-rode weerkaatsing wordt gebruikt om de zogenaamde Normalised Difference Vegetation Index (NDVI) te berekenen. De NDVI heeft een waarde tussen -1 en +1 . Hoe hoger de NDVI, hoe groener het gewas, en dus ook hoe hoger het gras. De metingen op Dairy Campus bevestigen dat de NDVI een goede maat is voor de grashoogte. Wel is het onderlinge verband niet hetzelfde op de drie meetdata en in erg lang gras is de NDVI wat minder onderscheidend.

\section{Weideresten}

Na beweiding is de grashoogte op goed afgegraasde plekken tussen de bossen zo'n 4 tot $8 \mathrm{~cm}$ lager dan de grashoogte op de geweigerde plekken in en rondom de bossen. De oppervlakte met relatief lang gras, na beweiding, is dus een indicator voor bosvorming. Een grenswaarde helpt dan bij het herkennen van bossen.

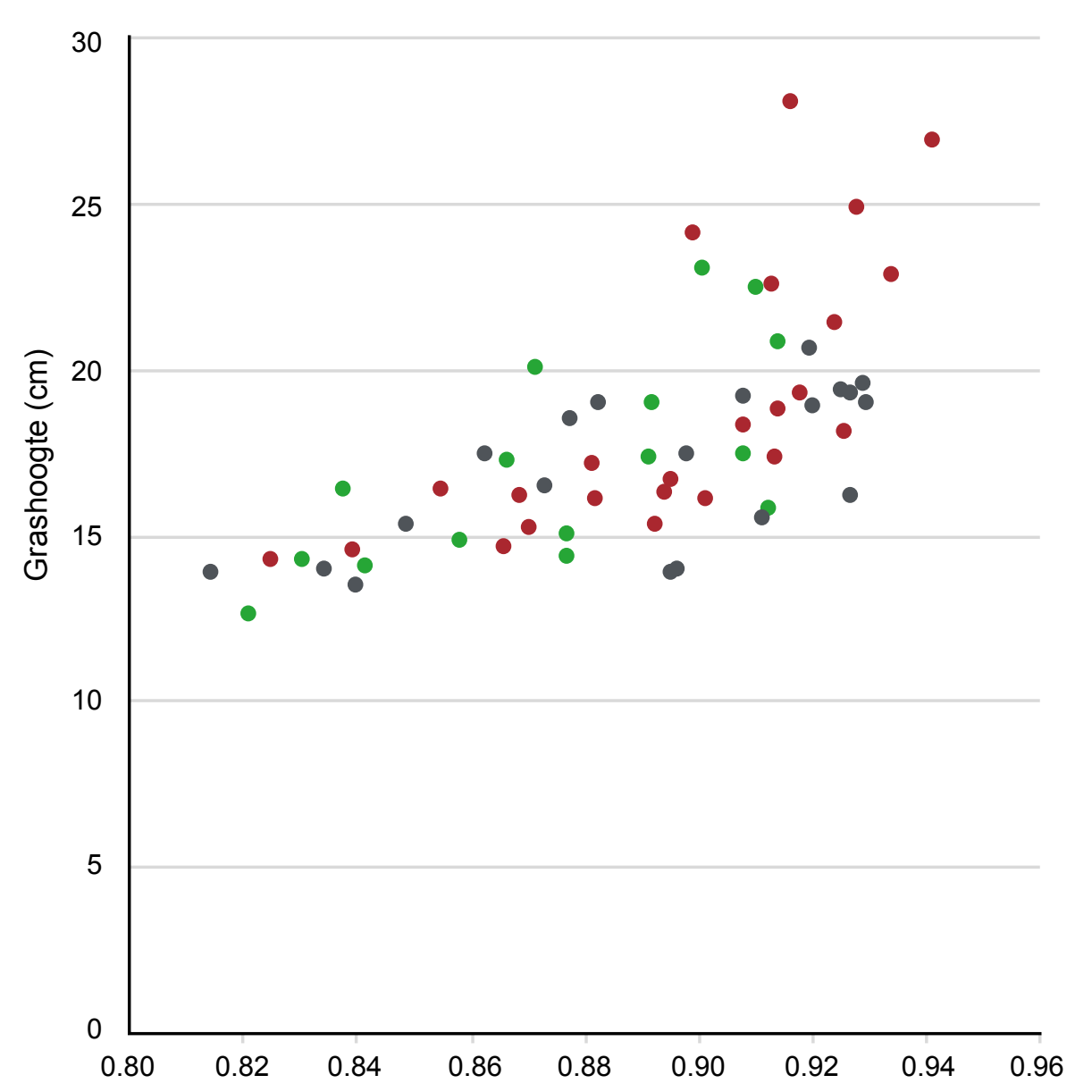

NDVI

Meetdatum: 19 juli 10 augustus $\quad 25$ augustus

De relatie tussen de gemiddelde grashoogte $(\mathrm{cm})$ en NDVI, gemeten op beweide percelen van Dairy Campus, op drie tijdstippen in 2017

$$
\text { Lees verder }
$$

\section{Grasvoorraad}

- Denken in platforms

- Feedwedge voor omweiden - Planning van standweiden

- Maaivenster en maaiplatform

- Grasaanbod

- Mestflatten en grasaanbod

- Drone herkent weiderest

- Remote sensing meet grasvoorraad

- Grasopbrengst schatten 
Naarmate de gemiddelde grashoogte van een beweid perceel hoger is, is ook de grenswaarde hoger. Vanwege het goede verband tussen grashoogte en NDVI, is er ook een grenswaarde voor de NDVI waarboven het gras aangemerkt kan worden als 'bos'. Ook hiervoor geldt dat de grenswaarde toeneemt naarmate de gemiddelde NDVI van het beweide perceel hoger is.

\section{Correctie op aanbod}

De dronebeelden zijn dus bruikbaar om de oppervlakte met geweigerde weideresten te berekenen. Deze kun je voor de aankomende beweiding aftrekken van de aangeboden oppervlakte om het werkelijke grasaanbod correct in te schatten.

\section{Verder lezen in rapporten van Amazing Grazing}

- Klootwijk et al., 2019. The potential of multispectral images to correct fresh grass allowance for selective grazing Precision Agriculture. In voorbereiding.

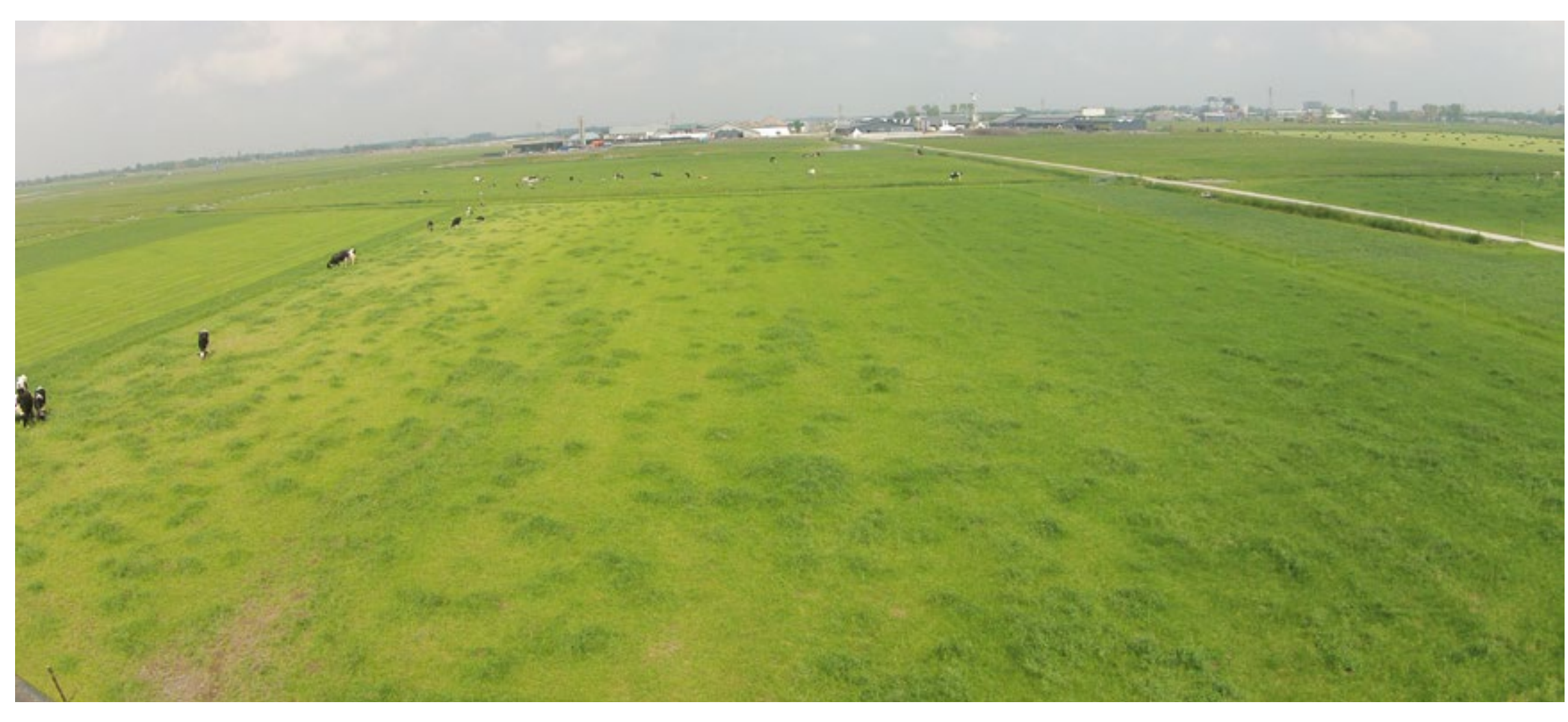

\section{Grasvoorraad}

- Denken in platforms

- Feedwedge voor omweiden - Planning van standweiden

- Maaivenster en maaiplatform

- Grasaanbod

- Mestflatten en grasaanbod

- Drone herkent weiderest

- Remote sensing meet grasvoorraad

- Grasopbrengst schatten

\begin{tabular}{cccc}
\hline Gemiddelde NDVI perceel & $\begin{array}{c}\text { Grenswaarde NDVI voor } \\
\text { detectie 'bos' }\end{array}$ & $\begin{array}{c}\text { Gemiddelde grashoogte perceel } \\
(\mathbf{c m})\end{array}$ & $\begin{array}{c}\text { Grenswaarde grashoogte } \\
\text { voor detectie 'bos' (cm) }\end{array}$ \\
\hline 0.80 & 0.85 & 6.6 & 8.2 \\
\hline 0.85 & 0.88 & 8.1 & 8.8 \\
\hline 0.90 & 0.92 & 9.1 & 9.3 \\
\hline 0.95 & 0.96 & 9.4 & 9.4 \\
\hline
\end{tabular}

Grenswaarde voor herkenning van bossen. Naarmate het gras hoger is, ligt de grenswaarde steeds dichter bij de gemiddelde grashoogte. Dat betekent dat bossen in langer gras moeilijker te onderscheiden zijn

\begin{tabular}{|c|c|c|}
\hline \multicolumn{2}{|c|}{} \\
\hline \multicolumn{2}{|c|}{} \\
\hline \hline Bijvoeding & Grasopname & Koegedrag \\
\hline \hline Grasgroei & Bodem & Grasvoorraad \\
\hline
\end{tabular}

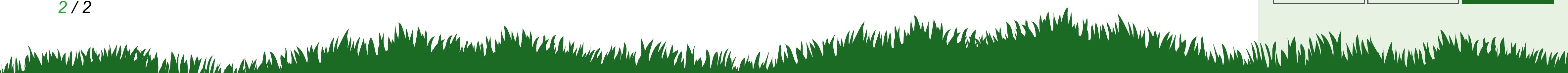




\section{Remote sensing meet grasvoorraad}

De planning van weiden en maaien vraagt om een zo goed mogelijke schatting van de actuele hoeveelheid gras in de wei. Spectrale reflectiemetingen met camera's kunnen snel een beeld geven van de grasvoorraad, maar de nauwkeurigheid moet beter.

\section{Multispectrale camera's}

Zonlicht bestaat uit straling van verschillende golflengten, oftewel verschillende kleuren. Groene planten zoals gras weerkaatsen vooral het groene licht, daarom zien we ze als groen. Daarnaast weerkaatst het het nabij infrarode licht, dat zien wij niet. Het rode en blauwe licht wordt maar voor een klein deel weerkaatst. De hoeveelheid gereflecteerd licht en de onderlinge verhouding tussen de gereflecteerde golflengten kunnen iets zeggen over gewaskenmerken zoals opbrengst en kwaliteit. De methode van reflectiemetingen is al tientallen jaren in ontwikkeling.
De camera's worden ook steeds beter. Bovendien is het mogelijk om met zogenaamde multispectrale camera's in één keer het gereflecteerde licht van een breed spectrum aan golflengten te meten.

\section{Vegetatie-index}

De onderlinge verhouding tussen de reflectie van licht van verschillende golflengeten wordt uitgedrukt in een zogenaamde vegetatie-index. Dat kan op verschillende manieren. De meest bekende is de NDVI (Normalised Difference Vegetation Index), die de verhouding tussen de reflectie van rood en nabij-infrarood licht berekent. De WDVI (Weighed Difference Vegetation Index) is een wat meer geavanceerde index die de NDVI corrigeert voor de reflectie van kale grond. De correctie kan worden berekend met de reflectie van rood licht (WDVI $\left.\mathrm{I}_{\text {rood }}\right)$ of groen licht (WDVI $\left.\mathrm{groen}_{\text {. }}\right)$.

\section{Grasvoorraad}

- Denken in platforms

- Feedwedge voor omweiden - Planning van standweiden

- Maaivenster en maaiplatform

- Grasaanbod

- Mestflatten en grasaanbod

- Drone herkent weiderest

- Remote sensing meet grasvoorraad

- Grasopbrengst schatten

\begin{tabular}{|c|c|c|}
\hline Bijvoeding & Grasopname & Koegedrag \\
\hline Grasgroei & Bodem & Grasvoorraad \\
\hline
\end{tabular}

Zonlicht bestaat uit straling van verschillende golflengten, die we zien als verschillende kleuren of die we helemaal niet zien. Groene planten absorberen vooral het rode en blauwe licht en reflecteren een deel van het groene licht. Het nabij-infrarode licht wordt grotendeels gereflecteerd 


\section{Platforms}

De camera's kunnen op verschillende 'platforms' worden gemonteerd: een maaier, een trekker, een drone, een helikopter, vliegtuig of satelliet. In Amazing Grazing is vooral gebruik gemaakt van twee typen van Cropscan Multispectral Radiometers (MSR87, MSR16R). De CropScans zijn speciaal voor onderzoek ontwikkeld als een soort gouden standaard en zijn uitgerust met camera's die de reflectie van acht of zestien golflengten meten. Ze worden handmatig over het veld bewogen, op een hoogte van ongeveer twee meter. Daarnaast is, uitsluitend op Dairy Campus, gebruik gemaakt van de Sensefly eBee RTK Deze is uitgerust met een camera die de reflectie van vier banden van golflengten meet. De camera op de eBee wordt voor elke vlucht gekalibreerd met een witte plaat waarvan de reflectiewaarde bekend is.

Lees verde

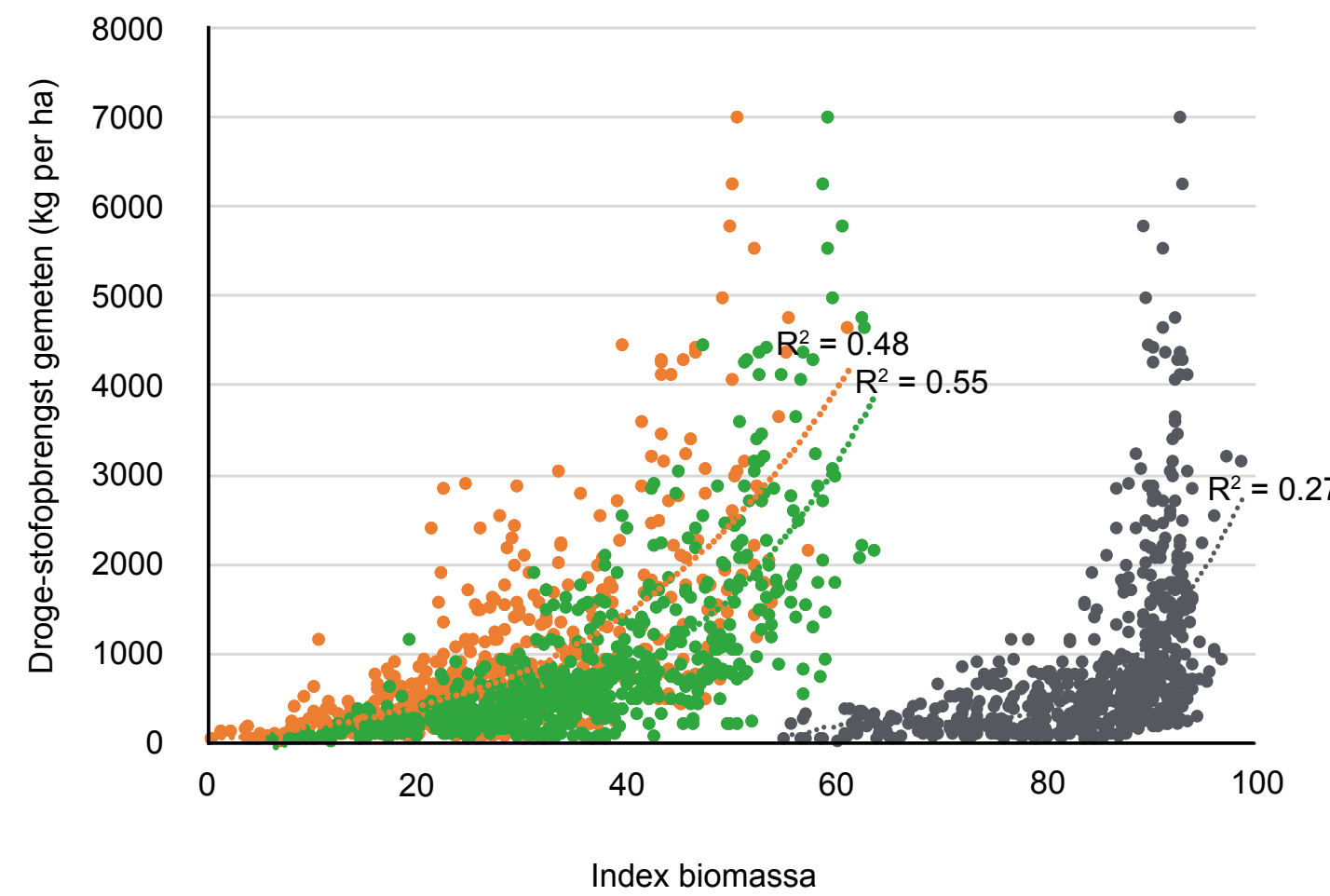

- $W D V I_{\text {groen }}$

- $W D V I_{\text {rood }}$

- NDVI

Relatie tussen drie vegetatie-indexen (WDVI , WDVI en NVDI) van de Cropscan en de droge-stofopbrengst van grasland voor de drie proeflocaties en beide proefjaren (2016-2017).

Per vegetatie-index is het percentage verklaarde variantie $\left(R^{2}\right)$ vermeld

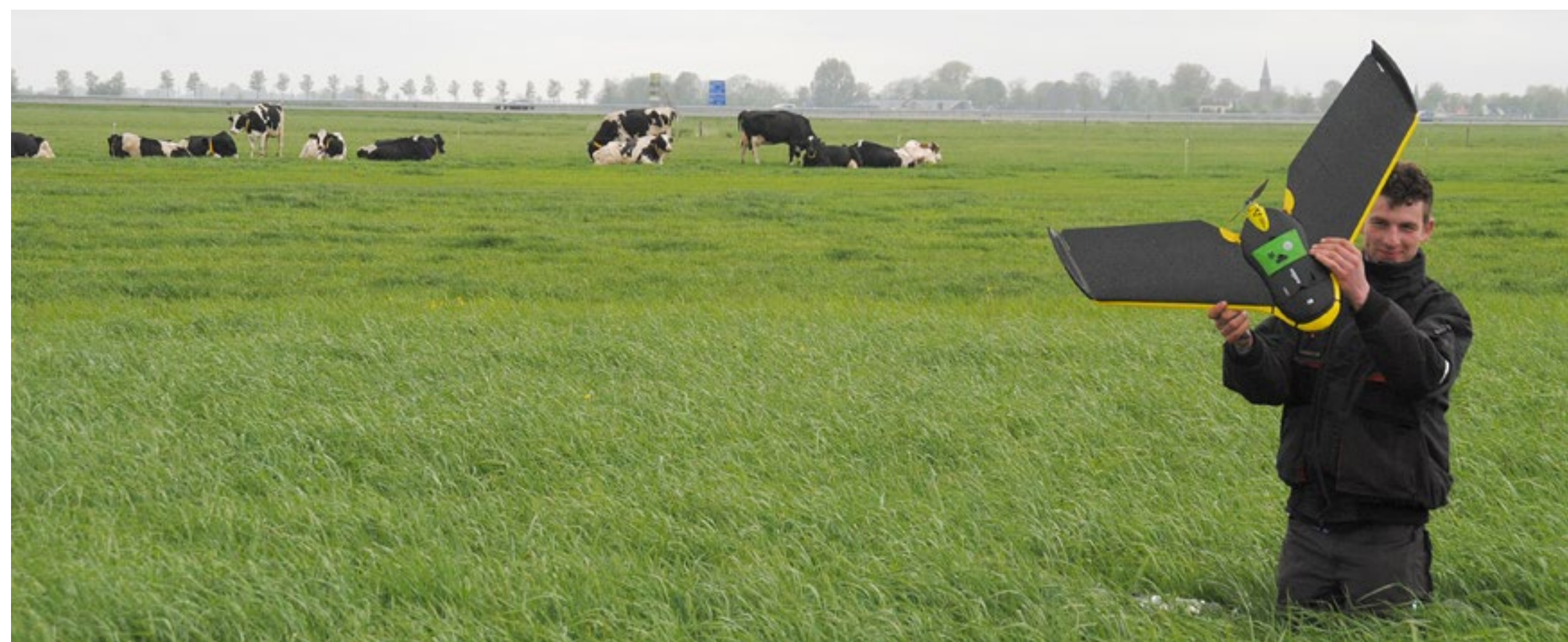

- Denken in platforms

- Feedwedge voor omweiden

- Planning van standweiden

- Maaivenster en maaiplatform

- Grasaanbod

- Mestflatten en grasaanbod

- Drone herkent weiderest

- Remote sensing meet grasvoorraad

- Grasopbrengst schatten 


\section{Relatie met droge-stofopbrengst}

De verschillende vegetatie-indexen van de Cropscan lieten een redelijk verband zien met de droge-stofopbrengst van gras. De WDVI's presteerden daarbij duidelijk beter dan de NDVI. Over het algemeen is de spreiding nog erg hoog waardoor het gebruik van een vegetatie-index voor de schatting van de droge-stofopbrengst onzeker blijft. Tot een opbrengst van 1500 à $2000 \mathrm{~kg}$ droge stof per ha is de schatting redelijk, maar bij hogere opbrengsten zijn de vegetatie-indexen niet meer onderscheidend omdat het signaal verzadigd raakt. Bij de Ebee was de NDVI de beste schatter, maar de nauwkeurigheid bleef achter bij de Cropscan.

\section{WDVI $_{\text {rood }}$ als schatter}

De WDVI ${ }_{\text {rood }}$ van de Cropscan kwam als beste vegetatie-index uit de bus. Daarbij maakte het niet uit of de metingen op Zegveld, Vredepeel of Dairy Campus waren uitgevoerd. Vergelijking van de opbrengstschattingen met behulp van WDVI $\mathrm{I}_{\text {rood }}$ en de werkelijke opbrengsten laten in het

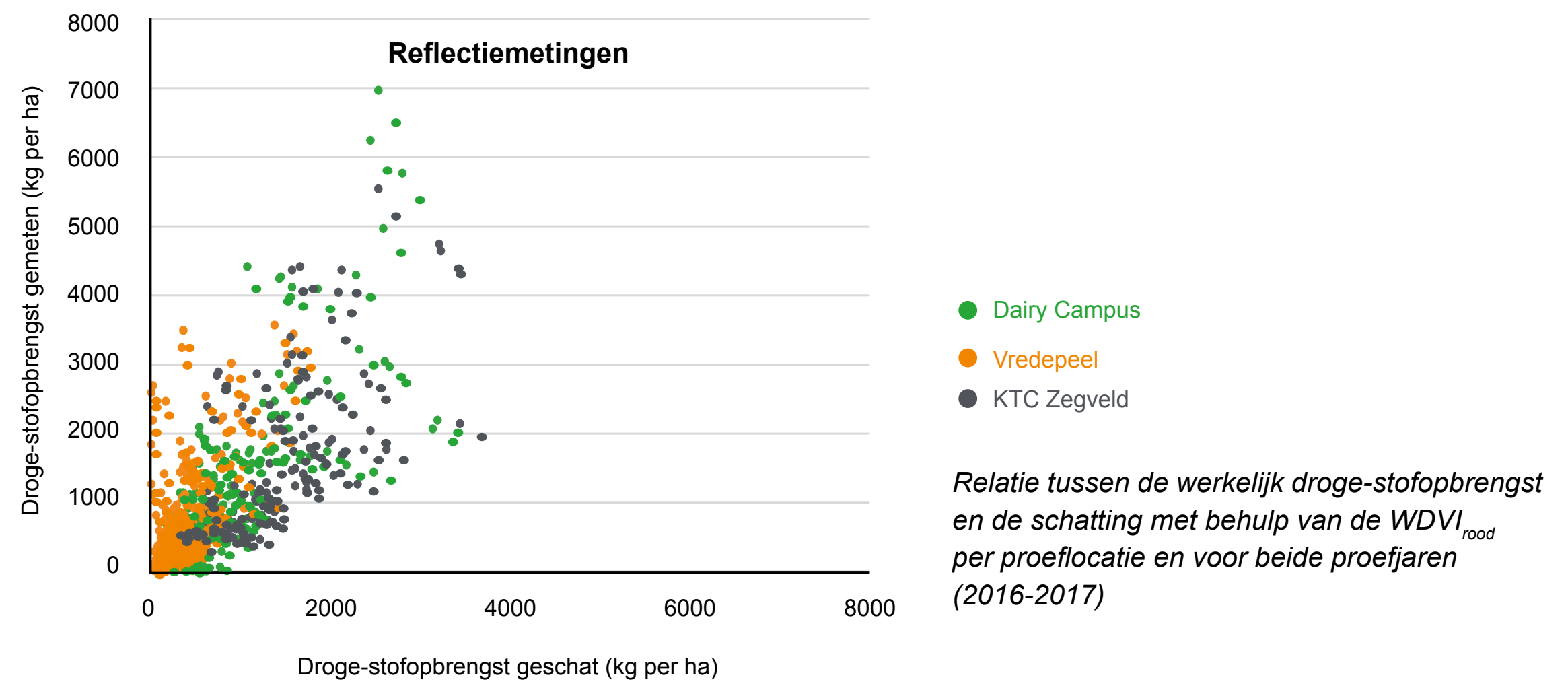

traject tot $2000 \mathrm{~kg}$ droge stof per ha een redelijk verband zien, al kunnen individuele punten er soms behoorlijk naast zitten. Bij de hogere opbrengsten neemt de nauwkeurigheid snel af. Bijvoorbeeld bij een geschatte opbrengst van $2500 \mathrm{~kg}$ droge stof per ha kan de werkelijke opbrengst wel tussen de 2000 en $7000 \mathrm{~kg}$ droge stof per ha liggen. Verschillen in opbrengsten tussen veldjes worden echter nauwkeuri- ger geschat en dat geeft perspectief voor de praktijk om met remote sensing graspercelen te rangschikken naar grasvoorraad.
- Denken in platforms

- Feedwedge voor omweiden - Planning van standweiden

- Maaivenster en maaiplatform

- Grasaanbod

- Mestflatten en grasaanbod

- Drone herkent weiderest

- Remote sensing meet grasvoorraad

- Grasopbrengst schatten 


\section{Grasopbrengst schatten - gecombineerde aanpak loont}

Goed plannen van weiden en maaien vraagt om een zo goed mogelijke schatting van de actuele hoeveelheid gras in de wei. Dat kan bijvoorbeeld met grashoogtemeters of reflectiemetingen. De combinatie van deze methoden met enkele kengetallen over grasgroei geeft een nog beter resultaat.

\section{Methoden vergelijken}

In Amazing Grazing zijn op drie proefvelden grashoogtemetingen en spectrale reflectiemetingen uitgevoerd om de drogestofopbrengst van grasland te schatten. De proefvelden lagen op Vredepeel (zand), Dairy Campus (klei) en Zegveld (veen). Om veel variatie te krijgen in de graslandopbrengsten bestond ieder proefveld uit combinaties van behandelingen met groeiduur en stikstofbemesting. De grashoogtemetingen zijn uitgevoerd met

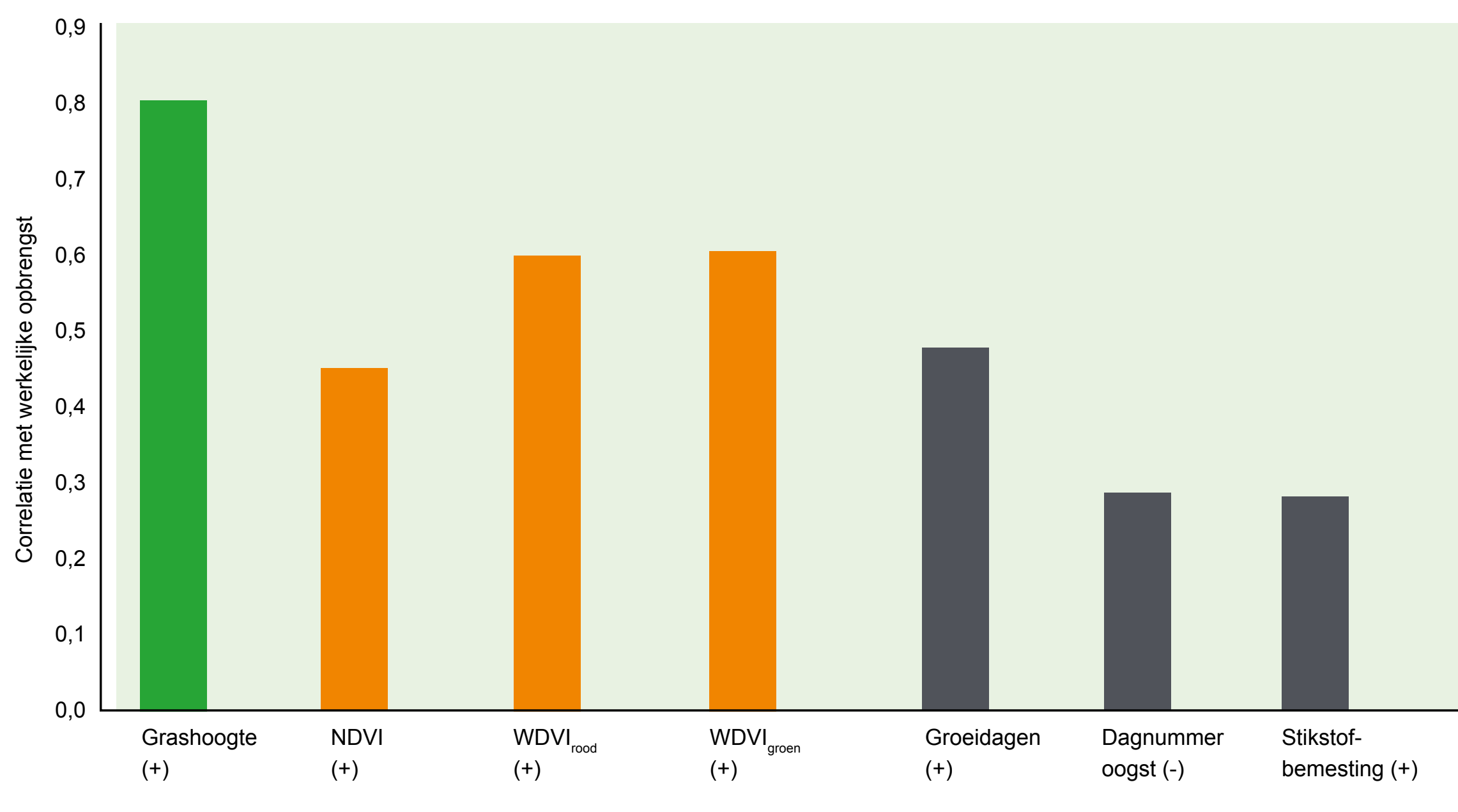

Correlatie tussen verschillende methoden en kengetallen met de werkelijk gemeten droge-stofopbrengst van grasland op drie locaties. Tussen haakjes staat de richting van de correlatie. [NDVI = Normalized difference vegetation index, $W D V I=$ Weighed Difference Vegetation Index]
- Denken in platforms

- Feedwedge voor omweiden

- Planning van standweiden

- Maaivenster en maaiplatform

- Grasaanbod

- Mestflatten en grasaanbod

- Drone herkent weiderest

- Remote sensing meet

grasvoorraad

- Grasopbrengst schatten

$$
\text { Lees verder } \Rightarrow
$$




\section{Grasvoorraad}

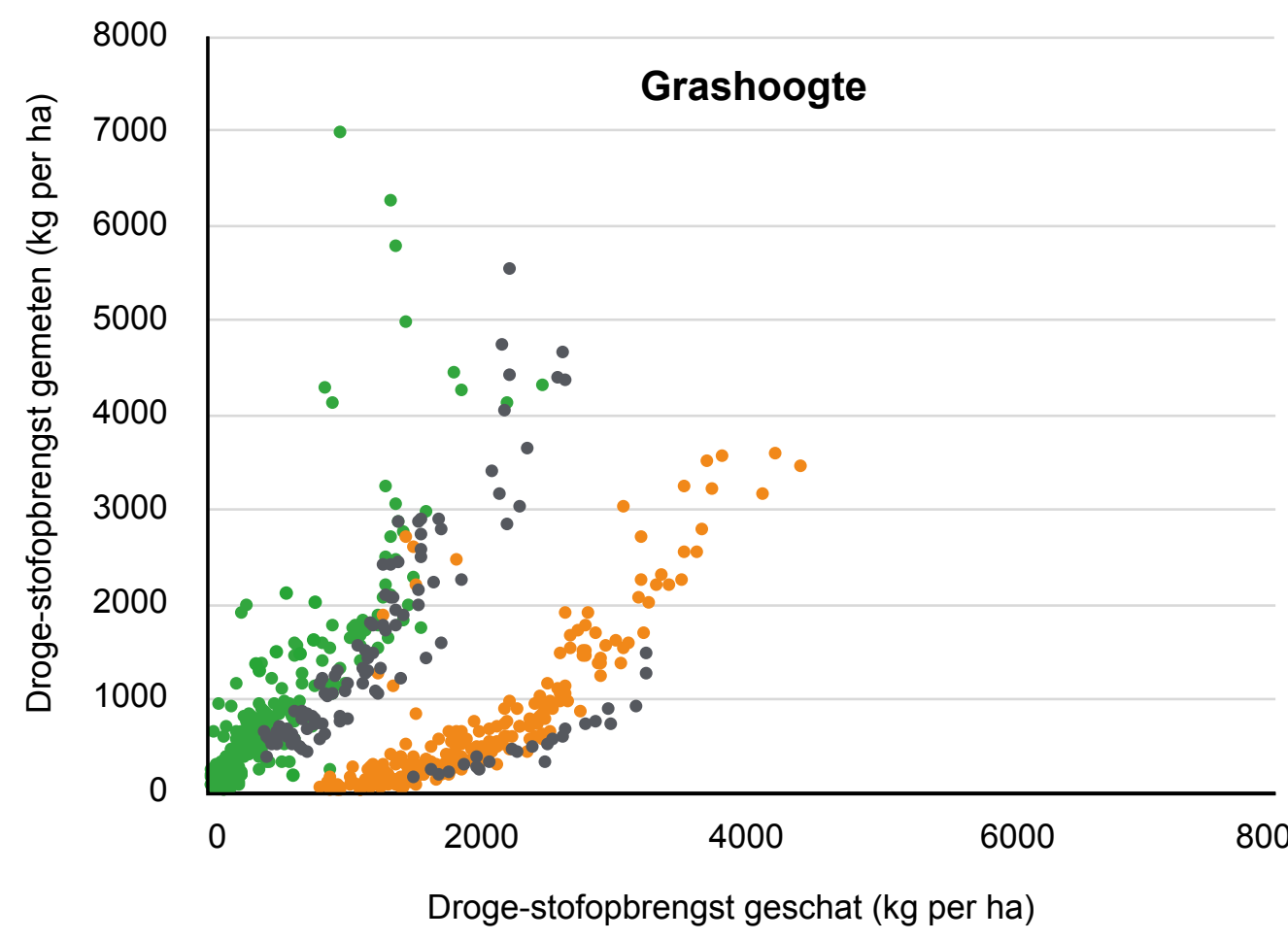

- Dairy Campus 2016-2017

Vredepeel 2016-2017

- KTC Zegveld

De schatting van de droge-stofopbrengst met alleen de grashoogtemeter (boven) wordt aanzienlijk beter als drie kengetallen over grasgroei (stikstofbemesting, groeidagen en

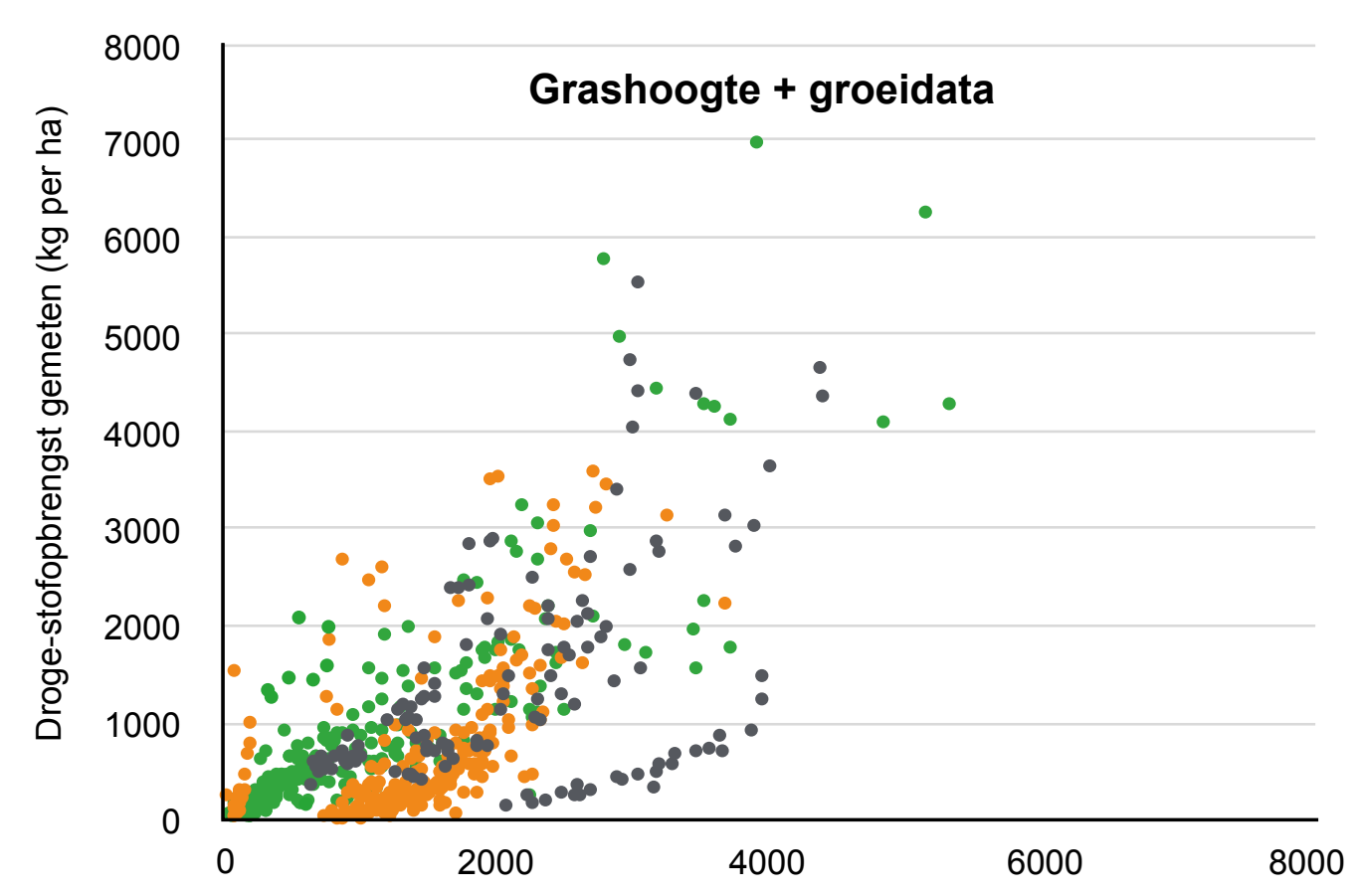
oogstdatum) worden toegevoegd (onder)

Dairy Campus 2016-2017

- Vredepeel 2016-2017

- KTC Zegveld
MSR16R) ingezet. Dit apparaat is ontwikkeld voor onderzoeksdoeleinden, maar in de praktijk zijn reflectiemetingen ook beschikbaar op andere platforms zoals drones of satellieten.

\section{Grashoogte}

Indien we alle methoden los beschouwen, blijkt de grashoogte de beste schatter te zijn voor de opbrengst. De reflectiemetingen zijn matige tot redelijke schatters.

Lees verder
Denken in platforms

- Feedwedge voor omweiden

- Planning van standweiden

- Maaivenster en maaiplatform

- Grasaanbod

- Mestflatten en grasaanbod

- Drone herkent weiderest

- Remote sensing meet

grasvoorraad

- Grasopbrengst schatten

\begin{tabular}{|c|c||c|}
\hline Bijvoeding & Grasopname & Koegedrag \\
\hline \hline Grasgroei & Bodem & Grasvoorraad \\
\hline
\end{tabular}


Opmerkelijk is dat een eenvoudig kengeta als het aantal groeidagen een vrijwel gelijke correlatie heeft als sommige vegetatie-indexen die op basis van de reflectiemetingen worden berekend. Als losse kengetallen zijn de stikstofbemesting en de oogstdatum matige schatters.

\section{Kengetallen en methoden combineren}

Het combineren van verschillende kengetallen en methoden verhoogt de nauwkeurigheid van de opbrengstschatting. De eerste zinvolle combinatie is een relatief eenvoudige stap: de drie kengetallen over grasgroei (stikstofbemesting, groeidagen en oogstdatum) zijn samen al minstens zo goed als het gebruik van een grashoogtemeter of een reflectiemeting. Een tweede zinvolle combinatie is vervolgens om de grashoogtemetingen te combineren met de kengetallen over grasgroei. Daarmee kom de schatting echt op een hoger niveau ten opzichte van de losse schattingsmethoden. Het combineren van alle beschikbare methoden is niet zo zinvol, omdat het weinig toevoegt.

\section{Eenvoudige uitbreiding}

De nauwkeurigheid van de grashoogtemetingen kan dus op een vrij eenvoudige manier worden verbeterd. De drie kengetallen zijn voor elke veehouder makkelijk beschikbaar: stikstofbemesting, groeidagen en oogstdatum. De benodigde berekeningen kunnen geautomatiseerd worden bij gebruik van een bedrijfsmanagementsysteem waarin graslandgebruik wordt vastgelegd. De koppeling van kengetallen over grasgroei en grashoogtemetingen helpen onder andere om het bekende euvel van grashoogtemetingen bij hoge opbrengstniveau's te corrigeren.

\section{Verder lezen in rapporten van Amazing Grazing}

- Hoving et al., 2019. Schatten van grasopbrengst op basis van spectrale reflectie, grashoogte en modellering, Livestock Research Report 1200, 2019.

\begin{tabular}{|c|c|c|}
\hline \hline Bijvoeding & Grasopname & Koegedrag \\
\hline \hline Grasgroei & Bodem & Grasvoorraad \\
\hline
\end{tabular}

\section{Grasvoorraad}

- Denken in platforms

- Feedwedge voor omweiden

- Planning van standweiden

- Maaivenster en maaiplatform

- Grasaanbod

- Mestflatten en grasaanbod

- Drone herkent weiderest

- Remote sensing meet

grasvoorraad

- Grasopbrengst schatten 


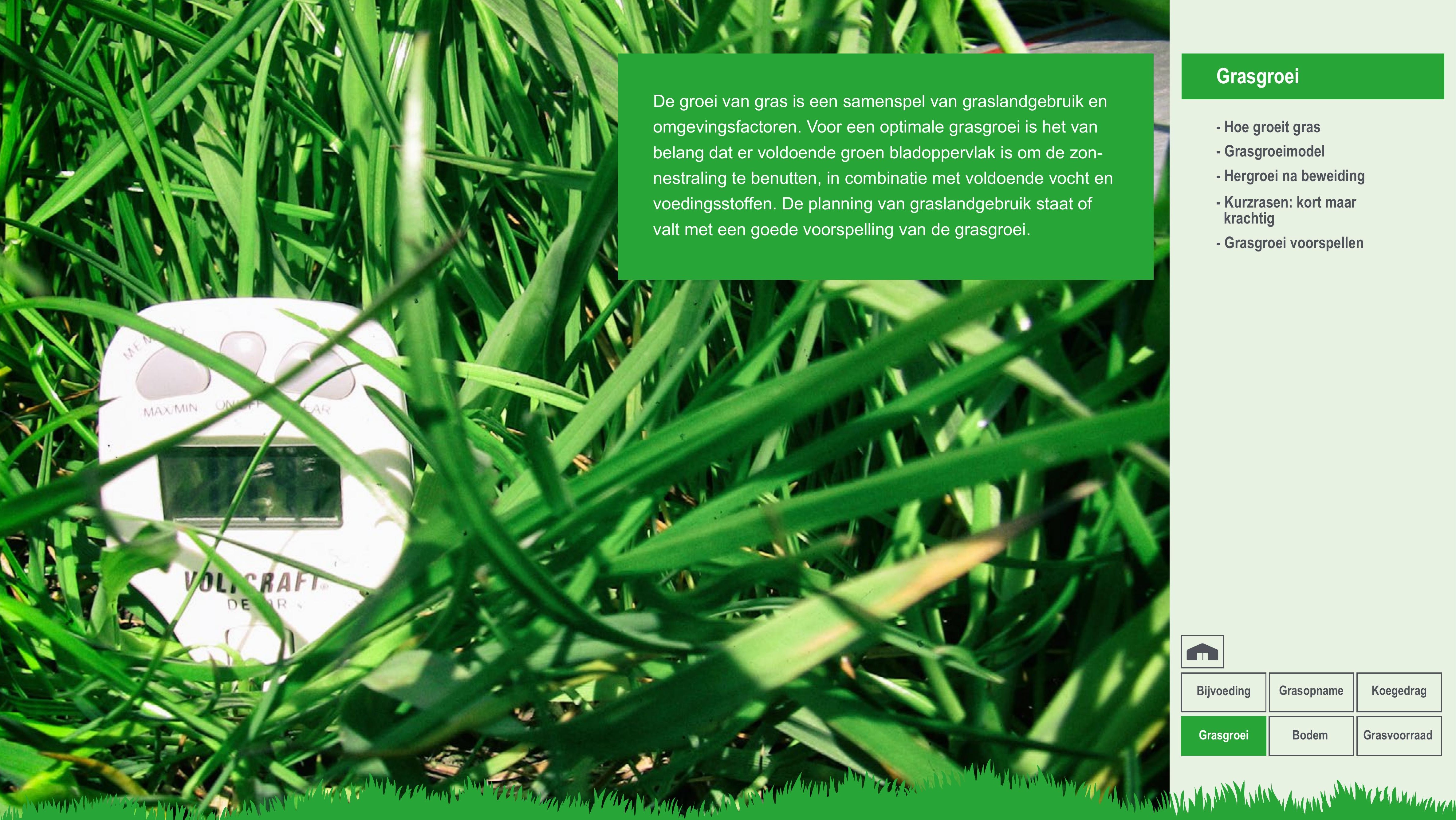




\section{Hoe groeit gras}

Tijdens het groeiseizoen van maart tot en met oktober is de gemiddelde dagelijkse grasgroei zo'n 50 tot $100 \mathrm{~kg}$ droge stof per ha. Hoe komt die groei tot stand?

\section{Fotosynthese}

Zonlicht is de drijvende kracht achter de groei van gras. Het gras gebruikt de onderschepte lichtenergie voor het omzetten van koolstofdioxide, water en voedingsstoffen als stikstof en fosfor tot organisch materiaal. Grofweg $5 \%$ van de totale jaarlijkse zonne-energie wordt vastgelegd in bovengrondse en ondergrondse delen van gras. De andere $95 \%$ van de zonne-energie landt buiten het groeiseizoen op of onbedekte grond of wordt gebruik voor gewasverdamping. Een klein deel van het zonlicht wordt ongebruikt teruggekaatst.

\section{Grasspruit}

De grasspruit is de fundamentele bouwsteen voor grasgroei. In het vegetatieve

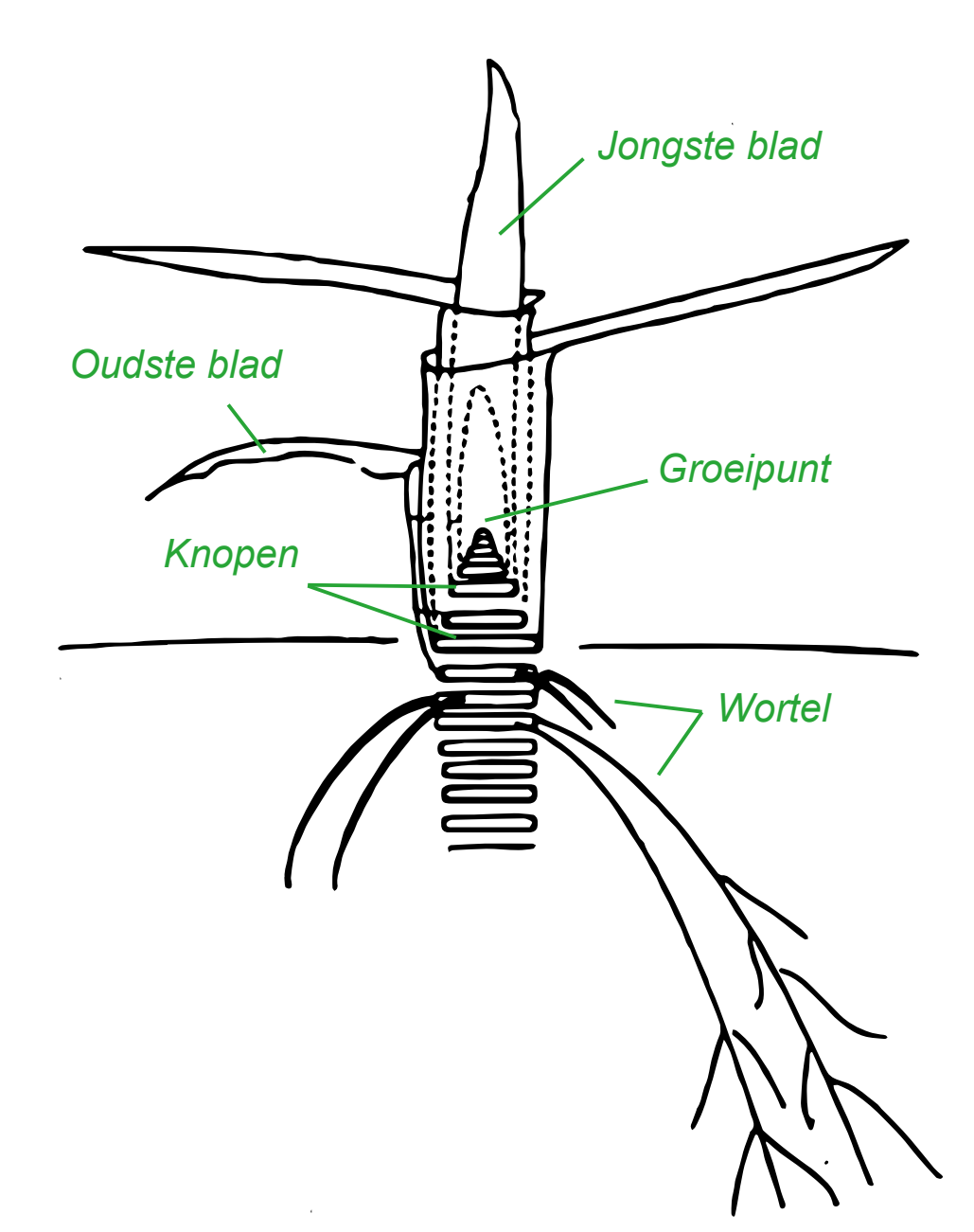

stadium, voor de bloei, is de stengel heel kort en in feite niet meer dan een zeer compacte opeenstapeling van zogenaamde knopen. Bovenaan deze stapel bevindt zich het groeipunt waaruit telkens nieuwe knopen ontstaan. Elke knoop kan een blad produceren. In de zomer verschijnt elke zeven tot tien dagen een nieuw blad. Een grasspruit heeft twee tot drie volgroeide bladeren en een onvolgroeid blad. Op het moment dat het vierde blad zich ontwik- keld, sterft het oudste blad ongeveer tegelijkertijd af. De droge-stofopbrengst van de levende bladeren neemt na een maand dus niet meer toe omdat er evenveel bijgroeit als afsterft. De stengels blijven wel doorgroeien waardoor de totale droge-stofopbrengst ook na een maand verder blijft toenemen. Elke knoop bevat ook een knop waaruit later een geheel nieuwe zijspruit kan groeien.

\section{Groeipunt}

Een spruit die bij het oogsten zijn groeipunt behoudt, groeit daarna gewoon door. Maar grasspruiten gaan in de loop van mei en juni over in het generatieve stadium (bloei). De stengel strekt zich uit tussen de knopen, waarbij het groeipunt ook hoger komt te liggen. Als het groeipunt zo hoog komt dat het wordt verwijderd bij weiden of maaien, sterft de spruit. Hergroei duurt dan langer omdat de groei dan moet plaatsvinden uit een nieuw te vormen spruit.

$$
\text { Lees verder }
$$

Grasgroei

- Hoe groeit gras

- Grasgroeimodel

- Hergroei na beweiding

- Kurzrasen: kort maar krachtig

- Grasgroei voorspellen 


\section{Temperatuur en vocht}

Engels raaigras groeit vanaf ongeveer $6^{\circ} \mathrm{C}$ (luchttemperatuur), en de groeisnelheid neemt verder toe tot zo'n $20^{\circ} \mathrm{C}$. Tot $15^{\circ} \mathrm{C}$ neemt de groei per graad Celsius toe met ongeveer $13 \mathrm{~kg}$ droge stof per ha per dag. In het traject tot $20^{\circ} \mathrm{C}$ is de toename per graad Celsius ongeveer $21 \mathrm{~kg}$ droge stof per ha per dag. Toenemende temperaturen zorgen voor een snellere bladverschijning en een snellere bladstrekking. Bij hogere temperaturen neemt bovendien de uiteindelijke bladlengte toe. 'Hoge temperatuur'-bladeren zijn naar verhouding langer, maar smaller dan 'lage temperatuur'bladeren.

De vochtvoorziening is een zeer belangrijke factor voor de grasgroei. Watertekort remt zowel de verschijningssnelheid als strekking van bladeren. Om waterverdamping af te remmen, worden de huidmondjes in de bladeren gesloten. De keerzijde is dat er ook minder koolstofdioxide via de huidmondjes wordt opgenomen met een lagere groei tot gevolg.

\section{Lichtintensiteit en daglengte}

De hoeveelheid licht is van groot belang voor de productie van droge stof. Bij relatief lage lichtintensiteiten benut een grasblad 12 tot $15 \%$ van het licht, maar bij zeer hoge zomerse lichtintensiteiten kan de benutting dalen tot wel 2 à $3 \%$. Hoe meer groen blad aanwezig is, hoe beter het gras het licht kan onderscheppen. De zogenaamde bebladeringsindex (Leaf Area Index $=\mathrm{LAl}$ ) is een maat voor de hoeveelheid blad en wordt uitgedrukt in $\mathrm{m}^{2}$ blad per $\mathrm{m}^{2}$ grond. Bij een gemaaide stoppel is de LAl grofweg gelijk aan 1 en wordt ongeveer $50 \%$ van het licht onderschept. Als er twee ton droge stof aan gras staat, is de LAl ongeveer 4 en wordt al bijna $90 \%$ van het licht onderschept. Bij een LAI van 5 à 6 is de lichtonderschepping bijna $100 \%$.

Daglengte speelt vooral een rol bij de bloei van gras. Voordat grassen kunnen bloeien moeten ze eerst een periode ondergaan met korte dagen en temperaturen tussen de $0^{\circ} \mathrm{C}$ en $10^{\circ} \mathrm{C}$. Pas na deze zogenaamde vernalisatie zijn ze klaar om te bloeien, als de dagen langer worden en de temperaturen toenemen.

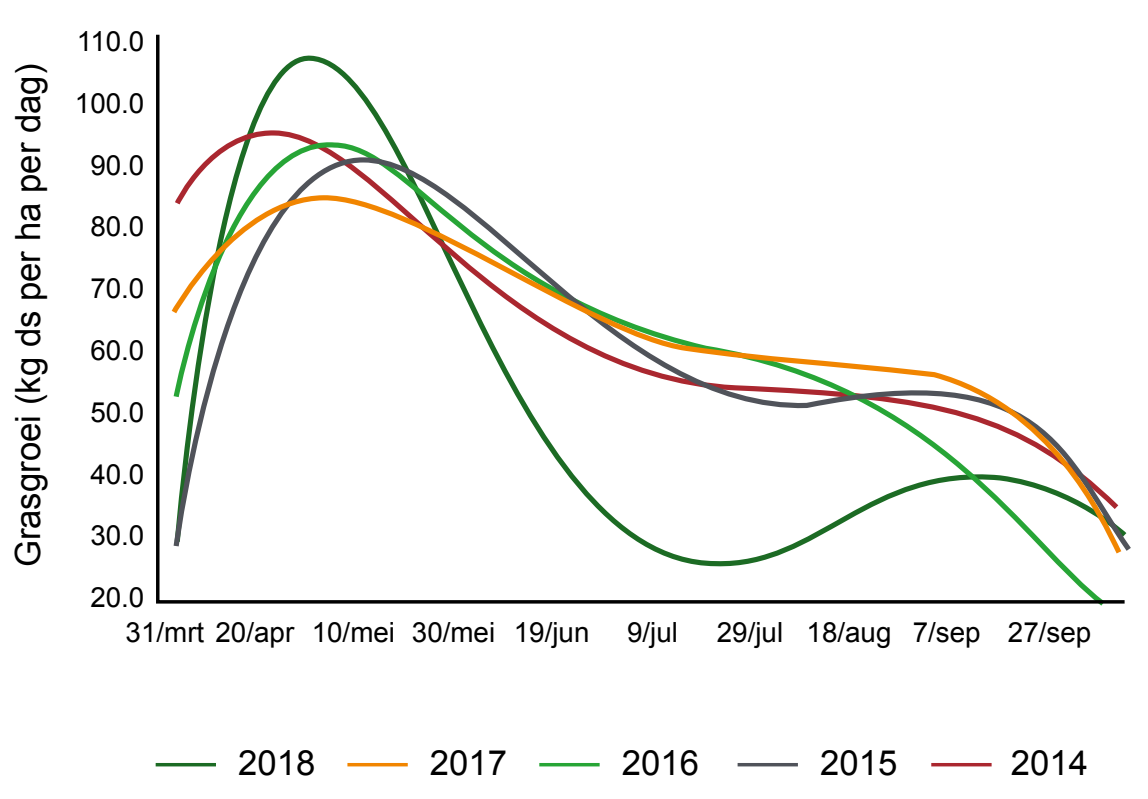

De groei van gras wordt, naast bemesting, vooral bepaald door temperatuur, vocht en licht. In het voorjaar zijn alle drie deze factoren nauwelijks beperkend voor de groei. In de zomer wordt de groei geremd door vochttekort en soms door te hoge temperaturen. In het najaar begint de temperatuur terug te lopen en in de herfst neemt ook de hoeveelheid zonlicht af. In de winter zijn de la lage temperaturen en korte dagen beperkend voor de groei. Deze getoonde grasgroei in de figuur is berekend uit grashoogtemetingen op proef-en praktijkbedrijven

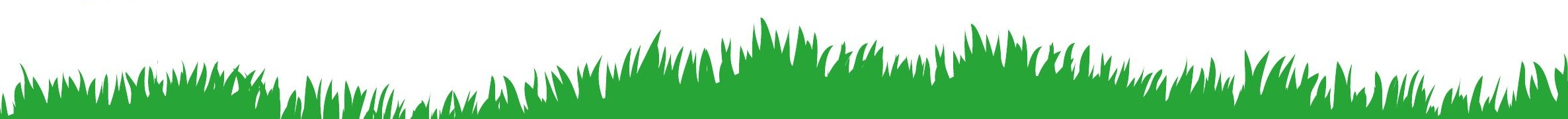




\section{Grasgroeimodel}

Het grasgroeimodel GRAS2007 simuleert het dagelijkse verloop van de productie en kwaliteit van gras onder Nederlandse omstandigheden.

\section{Rekenkern}

Het model is gebaseerd op een lange reeks van Nederlandse veldproeven op zand, klei en veen, vooral uitgevoerd in de tweede helft van de vorige eeuw. In iedere proef is het groeiverloop van een snede gemeten. De metingen omvatten natuurlijk de droge-stofopbrengst, maar ook het stikstofgehalte en de voederwaarde. Vervolgens zijn alle data gebruikt om verbanden te berekenen tussen verschillende invoervariabelen zoals dagnummer, stikstofbemesting, grondwaterstand, grondsoort, temperatuur, vochtvoorziening en de uitvoer zoals stikstofopname en droge-stofopbrengst.

Lees verder

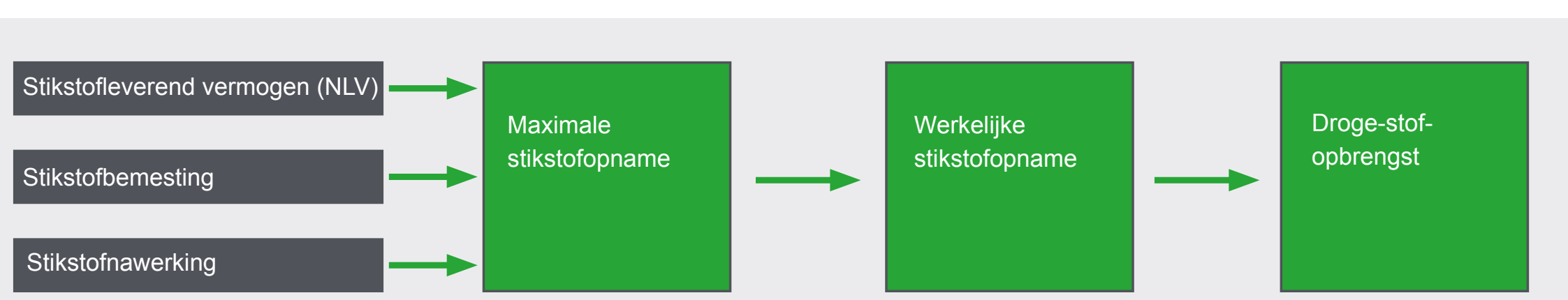

Vereenvoudigde weergave van de rekenkern van GRAS2007. Deze bestaat uit een set wiskundige vergelijkingen waarmee de maximale en werkelijke stikstofopname van gras wordt berekend in relatie tot de stikstofaanvoer uit de bodem, 'verse' bemesting en nawerking van eerdere bemestingen.

Vervolgens wordt de droge-stofopbrengst berekend uit de werkelijke stikstofopname.

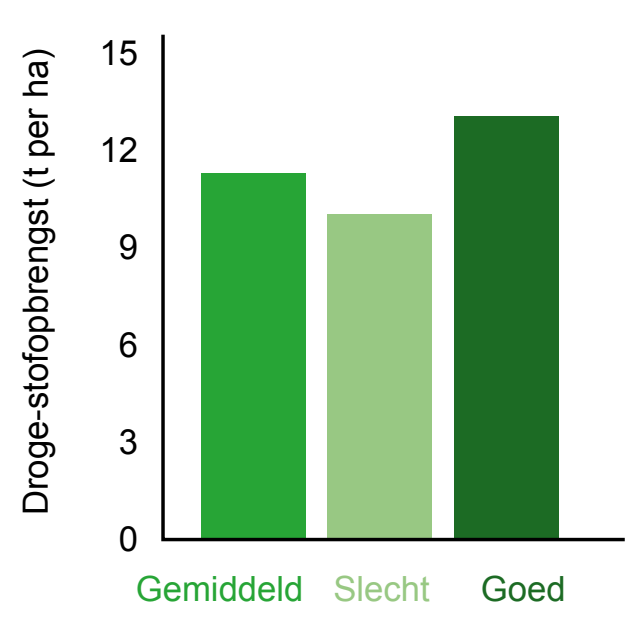

Grasjaar

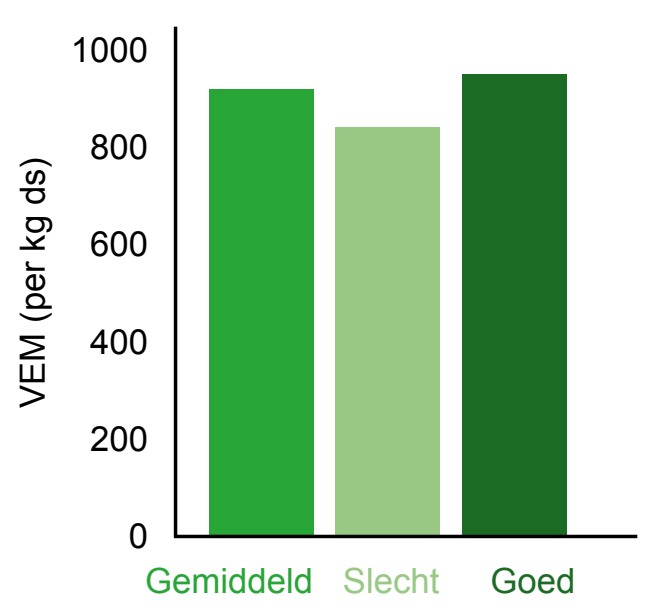

Grasjaar
Grasjaar

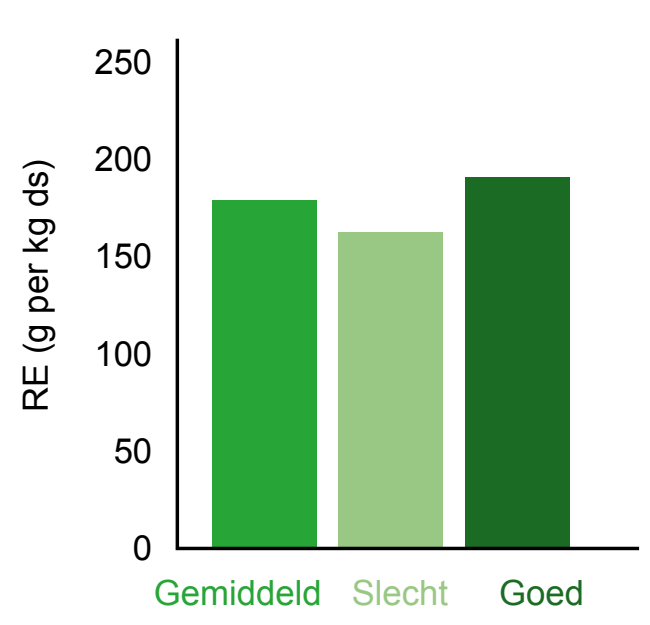

Gesimuleerde droge-stofopbrengst en kwaliteit van gras voor een zandgrond bij twee maaisneden en vier weidesneden; gemiddeld tussen 1990 en 2014, en in een typisch goed (2012) en slecht grasjaar (1996)

\section{Grasgroei}

- Hoe groeit gras

- Grasgroeimodel

- Hergroei na beweiding

Kurzrasen: kort maar krachtig

- Grasgroei voorspellen 


\section{Gemiddeld groeiverloop}

Voor vrijwel alle denkbeeldige situaties in Nederlands productiegrasland is het mogelijk om de groei van een individuele snede te simuleren. Dat betekent dat veehouders, adviseurs en onderzoekers een veelzijdig hulpmiddel hebben om toe te passen bij de

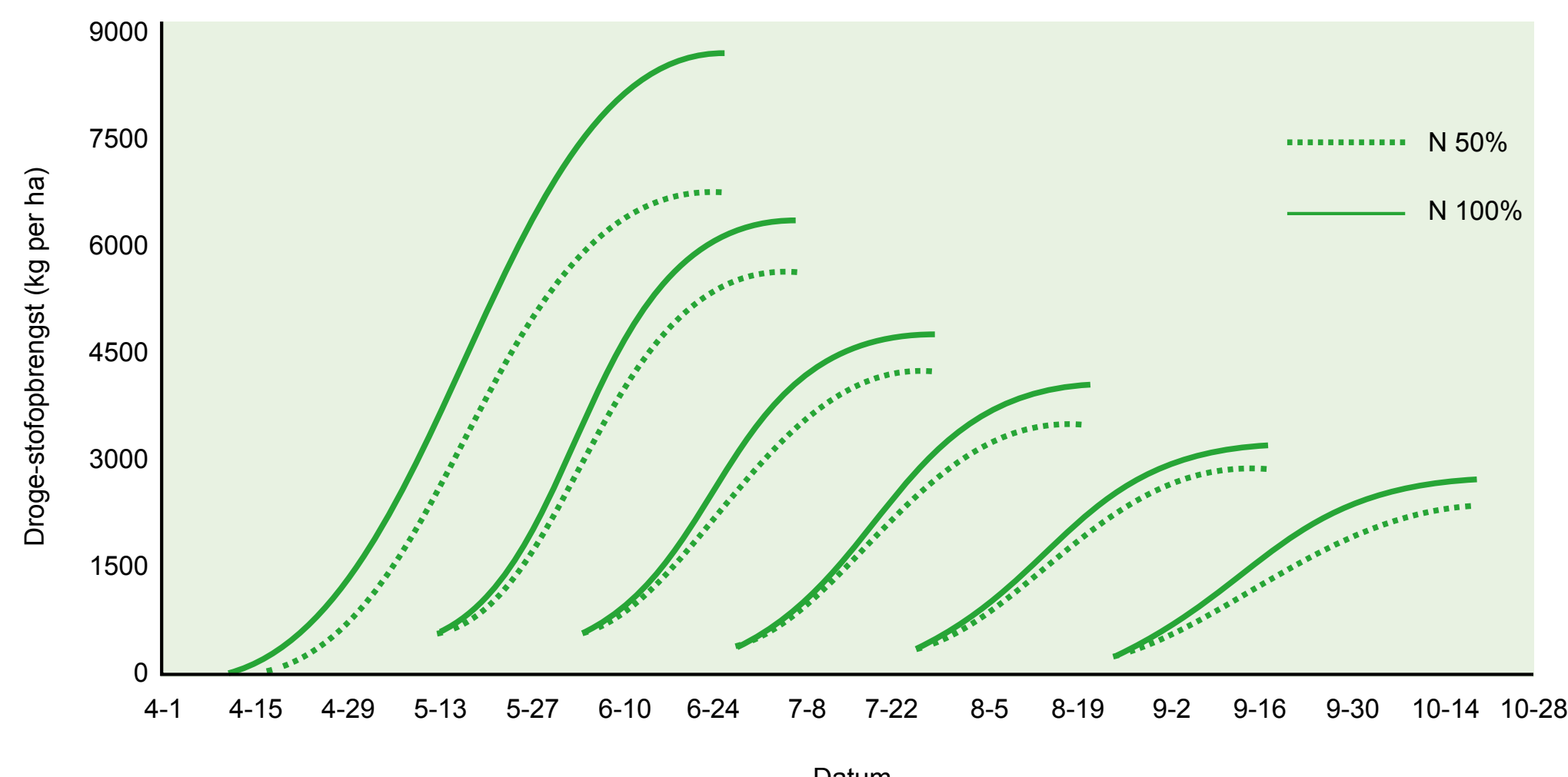

Datum

Groeiverloop van de eerste tot en met zesde snede van grasland op zandgrond in relatie tot de stikstofbemesting. De stikstofgift bij 100\% is gelijk aan 120, 90, 60, 60, 30 en $30 \mathrm{~kg} / \mathrm{ha}$ voor respectievelijk de eerste tot en met zesde snede

planning en evaluatie van het graslandgebruik. Indien de startdatum van de groei, de stikstofbemesting en het voorafgaand gebruik bekend zijn, kan het model bijvoorbeeld berekenen op welke dag een percee beweid of gemaaid kan worden, en welke kwaliteit gras er dan staat.

\section{Weer}

GRAS2007 houdt rekening met temperatuur en vochtvoorziening, zodat onderscheid kan worden gemaakt tussen verschillende jaren. De invloed van de dagelijkse temperatuur op de grasgroei simuleert het model indirect via zogenaamde temperatuurgroeidagen. GRAS2007 berekent eveneens per dag de vochtvoorziening van het gras, rekening houdend met neerslag, capillaire nalevering en gewasverdamping. Eventuele vochttekorten remmen de dagelijkse grasgroei.

\section{Grasgroei}

- Hoe groeit gras

- Grasgroeimode

- Hergroei na beweiding

Kurzrasen: kort maar krachtig

- Grasgroei voorspellen 


\section{Hergroei na beweiding}

$\mathrm{Na}$ beweiding is de overblijvende stoppel een mengelmoes van gras met verschillende lengten. Wat betekent dat voor de hergroei van gras?

\section{Groen blad}

De snelheid waarmee een grasplant herstelt na beweiding is afhankelijk van de aanwezigheid van de groeipunt en de hoeveelheid groen blad. Mocht het gras zo kort zijn afgeweid, of gemaaid, dat de groeipunt is verwijderd, dan begint de hergroei meteen al met een achterstand vanuit een nieuw te vormen zijspruit. De hoeveelheid groen blad bepaalt hoe snel het gras uit de startblokken komt. Normaal gesproken, tot een grashoogte van circa $15 \mathrm{~cm}$, geldt hoe meer blad, des te sneller de hergroei. Maar daarboven gaat dat niet meer op omdat dan ook meer oudere bladeren afsterven. Netto is de groei dan gelijk of zelfs lager.

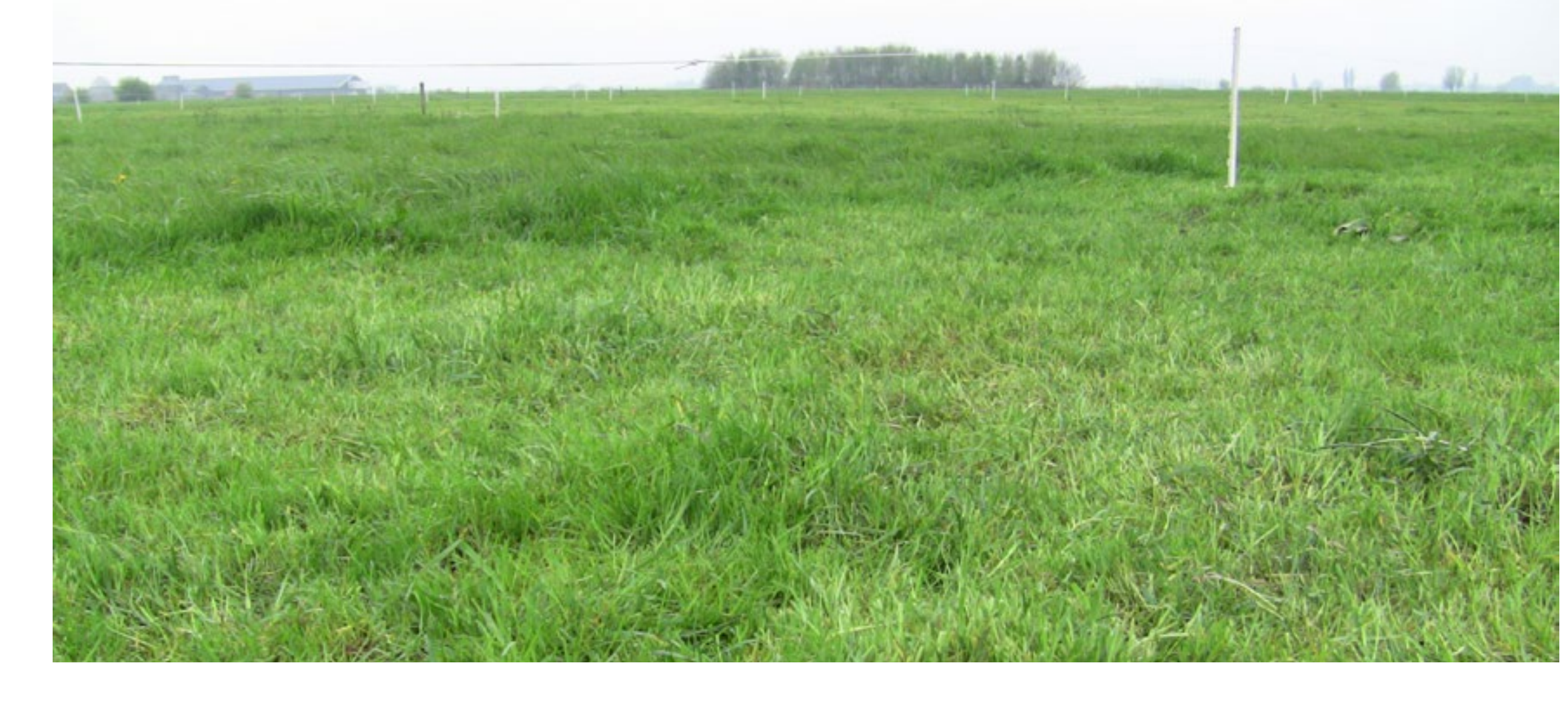

\section{Weide mozaïek}

Weidende koeien laten een mozaïek van verschillende grashoogten achter. Op de ene plek is het gras bijna tot de grond kaalgevreten, terwijl een beetje verderop lange resten van geweigerd gras zijn blijven staan; en ook nog plekken met alle grashoogten daartussenin. In Amazing Grazing is in 2018 op Dairy Campus een proef uitgevoerd om de groeisnelheid van gras te meten vanuit een beginsituatie met verschillende stoppellengten. $\mathrm{Na}$ de eerste, tweede en derde snede werden veldjes gemaaid op een stoppelhoogte van 5 , $8,11,15$ of $18 \mathrm{~cm}$ om de invloed van beweiding zo goed mogelijk na te bootsen.
Grasgroei

- Hoe groeit gras

- Grasgroeimodel

- Hergroei na beweiding

Kurzrasen: kort maar krachtig

- Grasgroei voorspellen

\begin{tabular}{|c|c|c|}
\hline Bijvoeding & Grasopname & Koegedrag \\
\hline Grasgroei & Bodem & Grasvoorraad \\
\hline
\end{tabular}

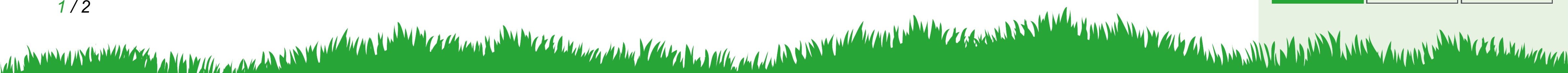


Vervolgens werden de veldjes in de tweede, derde of vierde snede geoogst als maaisnede. Bij een stoppel van $5 \mathrm{~cm}$ groeide het gras dagelijks zo'n 75 tot 125 $\mathrm{kg}$ ds/ha. Hoe hoger de stoppel, hoe snel-

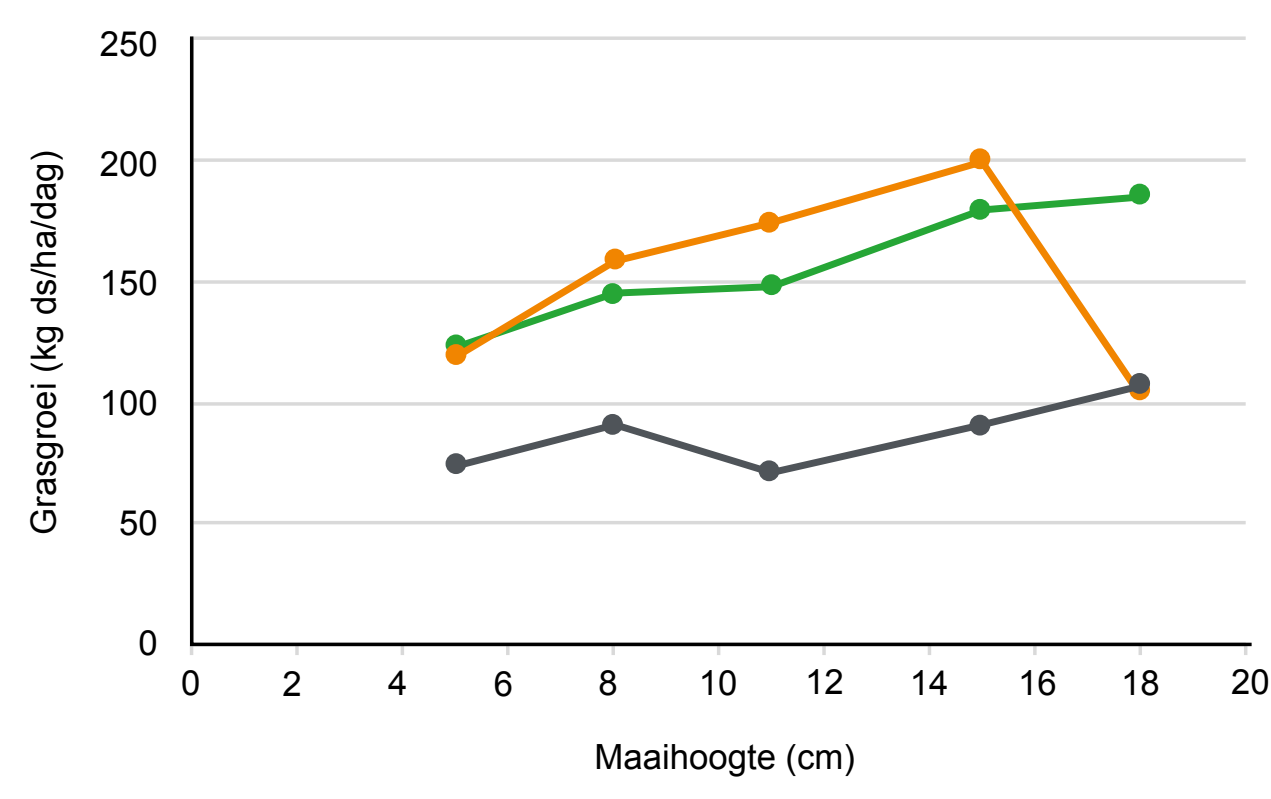

$\multimap$ Snede $2 \quad \longrightarrow$ Snede $3 \quad \longrightarrow$ Snede 4

Grasgroei ( $\mathrm{kg} \mathrm{ds} / \mathrm{ha} / \mathrm{dag}$ ) in relatie tot de stoppellengte van de tweede, derde en vierde snede op Dairy Campus in 2018 ler het gras groeide. Bij een stoppel van 15 of $18 \mathrm{~cm}$ was de grasgroei zo'n 100 tot $200 \mathrm{~kg} \mathrm{ds} / \mathrm{ha}$. Uit de resultaten is een gemiddelde extra groei berekend van ongeveer een 0,5 tot $4 \%$ per $\mathrm{cm}$ extra stoppel- lengte. Deze kennis is gebruikt om de voorspelling van de grasgroei na beweiding te verbeteren.
- Hoe groeit gras

- Grasgroeimode

- Hergroei na beweiding

- Kurzrasen: kort maar krachtig

- Grasgroei voorspellen

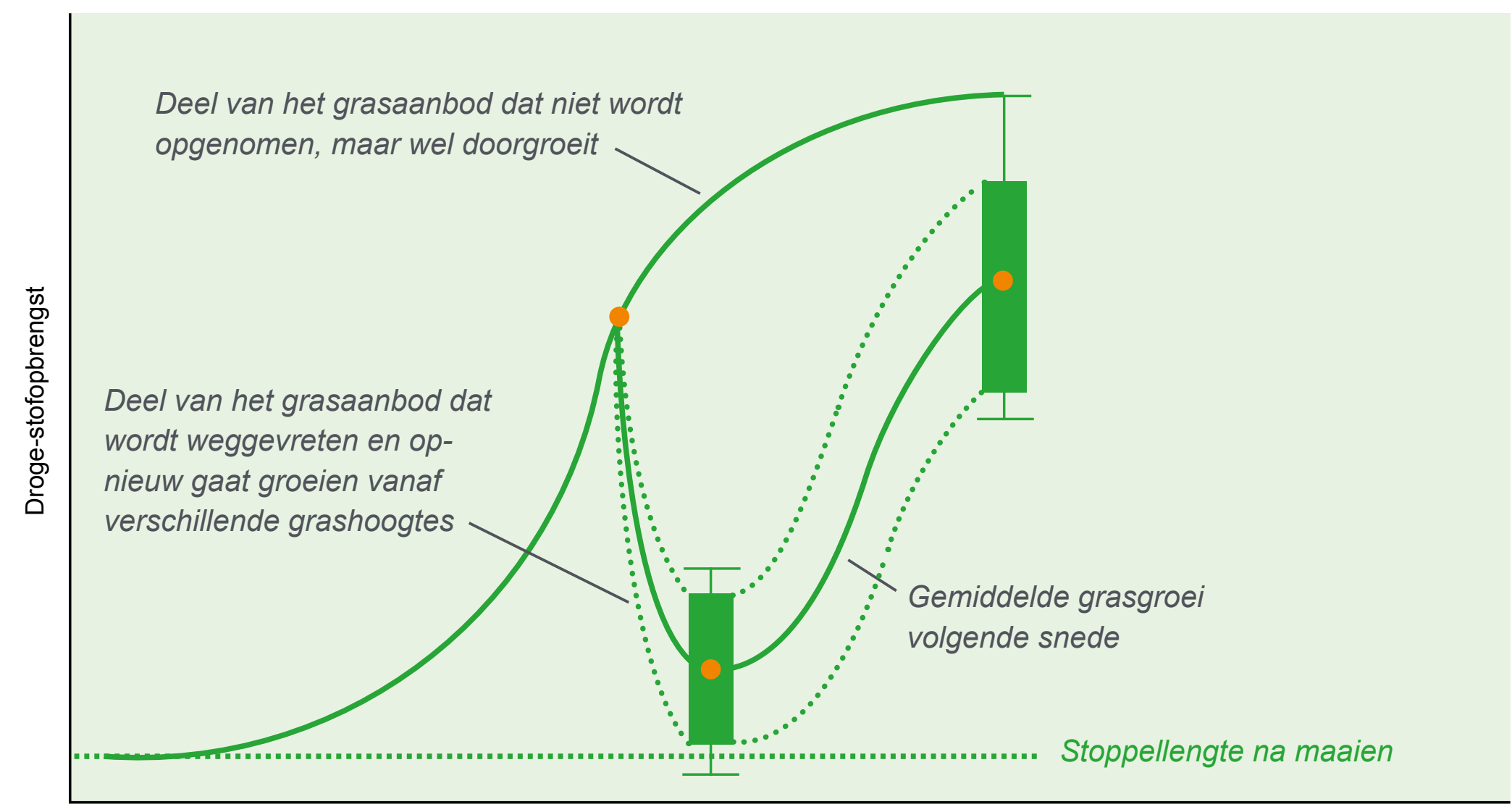

Opeenvolgende snedes

De grasgroei na beweiding begint vanuit verschillende stoppellengten. Een deel wordt afgevreten to verschillende lengten, waaruit het opnieuw uitgroeit. Een ander deel wordt niet aangevreten en groeit ongestoord verder

\section{7}

\begin{tabular}{|c|c|c|}
\hline Bijvoeding & Grasopname & Koegedrag \\
\hline Grasgroei & Bodem & Grasvoorraad \\
\hline
\end{tabular}




\section{Kurzrasen: kort maar krachtig}

Kurzrasen is een standweide met een grashoogte van 3 tot $5 \mathrm{~cm}$. Dat lijkt wel erg kort. Maar door een aangepaste groeiwijze van het gras levert de groei niet al teveel in.

\section{Lagere grasopbrengst}

Kort en vaak weiden is in theorie niet goed voor de groei van gras. Toch is dat precies wat Kurzrasen inhoudt. In vergelijking met omweiden of stripgrazen is de hoeveelheid groen blad klein waardoor het gras nooit maximaal kan groeien. Op proefbedrijf Zegveld was de droge-stofopbrengst van grasland bij kurzrasen inderdaad 13\% (2016) en 24\% (2017) lager dan bij stripgrazen, maar het verschil was beduidend kleiner dan de ruim $30 \%$ waarop gerekend werd.

\section{Andere dynamiek}

Tijdens de beweidingsproeven op Zegveld zijn regelmatig gedetailleerde metingen uitgevoerd aan individuele plantjes Engels raaigras. Bij kurzrasen, waar continu werd beweid, had elke spuit gras gemiddeld drie bladeren waarvan er één nog niet aangevreten was. Bij stripgrazen, voordat het beweiden begon, hadden de spruiten gemiddeld ook drie bladeren, waarvan er nog twee helemaal intact waren. Dat betekent dat er nog één aangevreten blad over was van de vorige beweidingsronde. $\mathrm{Na}$ de beweiding bij stripgrazen hadden de spruiten gemiddeld nog twee bladeren over, die uiteraard vrijwel allemaal aangevreten waren.

\section{Hogere blad-stengel verhouding}

Naast de tellingen van het aantal bladeren, is ook de lengte gemeten van de bladschijf en de schijnstengel. Bij kurzrasen was de totale lengte van alle bladschijven gemiddeld ongeveer negen centimeter. De lengte van de schijnstengel was drie centimeter, waardoor de blad-stengel verhouding ruim drie was. Zoals verwacht, nam de

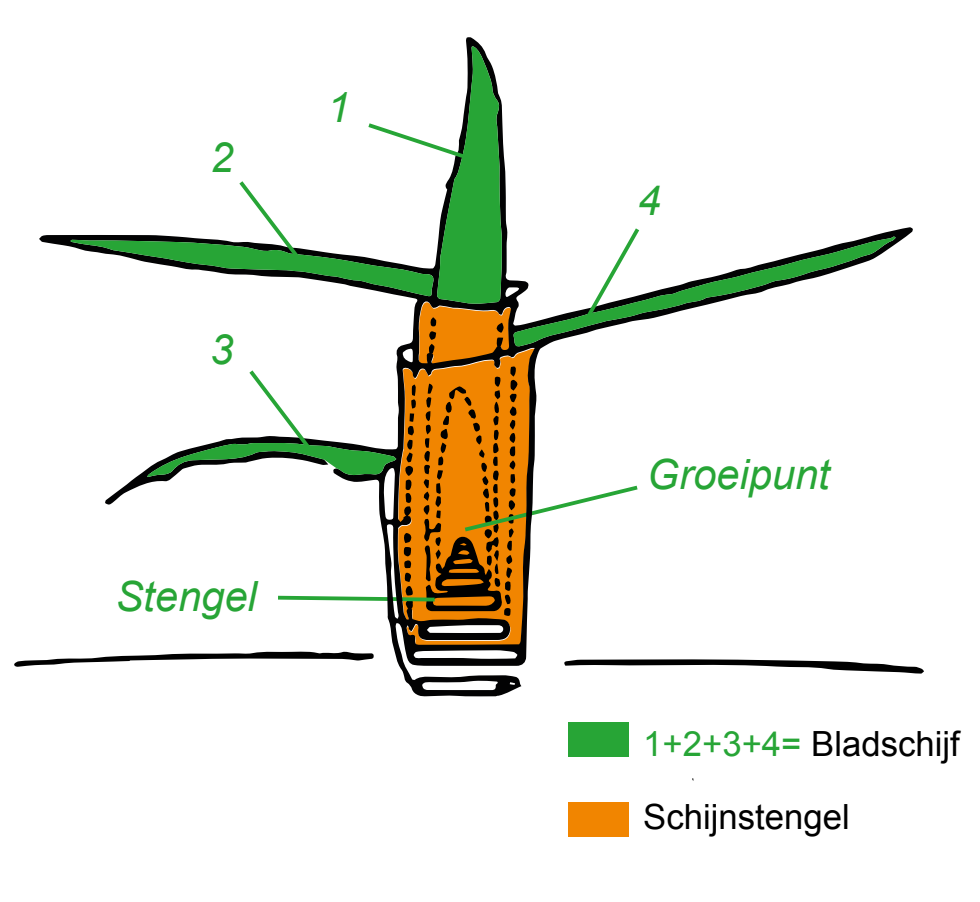

In de praktijk worden de termen stengel en blad bij gras wat losjes gebruikt. Zolang het gras niet gaat bloeien is de echte stengel zeer kort en niet zichtbaar. Het blad de echte stengel zeer kort en niet zichtbaar. Het blad
bestaat uit twee delen. Ten eerste de bladschijf, die als het ware in de lucht hangt. Dat is wat in de regel het 'blad' wordt genoemd. Ten tweede de bladschede, het onderste deel. De elkaar omsluitende bladscheden vormen een soort kokertje. Dat is wat in de regel de 'stengel' wordt genoemd, maar in strikte zin een schin'stengel' wordt genoemd, maar in strikte zin een schijnstengel is. De lengte van de bladschijf is de som van de groen gemarkeerde delen

- Grasgroei voorspellen

\begin{tabular}{|c|c|c|}
\hline Bijvoeding & Grasopname & Koegedrag \\
\hline Grasgroei & Bodem & Grasvoorraad \\
\hline
\end{tabular}


lengte van de bladschijf bij stripgrazen tijdens beweiding sterk af; van ongeveer dertig naar zes centimeter. De stengellengte nam ook af, maar veel minder; van zeven à acht naar zes centimeter. Vanwege de grote afname van de bladschijf en de geringe afname van de schijnstengel, daalde de blad-stengelverhouding bij stripgrazen van vier naar een.

\section{Betekenis voor groei}

Nadat een grasplantje is afgegraasd, komt de hergroei vooral tot stand uit de opgeslagen suikerreserves in de wortel en stengel. Daarnaast kan het restant groen blad direct bijdragen aan de hergroei door middel van fotosynthese. Hoe korter het gras is afgeweid, hoe meer de plant afhankelijk is van de reserves. Bij kurzrasen is er op elk moment een redelijk constante hoeveelheid groen blad over, waardoor de plant minder afhankelijk is van de wortelen stengelreserves. Er is altijd ruim drie keer zoveel bladschijf als schijnstengel

Lees verder

\begin{tabular}{rccc} 
& Kurzrasen & $\begin{array}{c}\text { Stripgrazen } \\
\text { voor weiden }\end{array}$ & $\begin{array}{c}\text { Stripgrazen } \\
\text { na weiden }\end{array}$ \\
\hline Bladeren per spruit $(\mathrm{n})$ & 3,0 & 3,0 & 2,1 \\
\hline Niet aangevreten bladeren per spruit $(\mathrm{n})$ & 1,2 & 2,0 & 2,0 \\
\hline Lengte bladschijven $(\mathrm{cm})$ & 9,4 & 30,2 & 5,9 \\
\hline Lengte schijnstengel $(\mathrm{cm})$ & 2,9 & 7,5 & 6,0 \\
\hline Blad-stengel verhouding & 3,2 & 4,0 & 1,0 \\
\hline
\end{tabular}

In voorjaar, zomer en najaar van 2016 en 2017 zijn bij kurzrazen en stripgrazen, voor en na beweiding, telkens 50 spruiten Engels raaigras afgeknipt en vervolgens uit elkaar gerafeld. Van elke spruit werd het aantal bladeren geteld en de totale lengte van de bladschijven en de schijnstengel gemeten

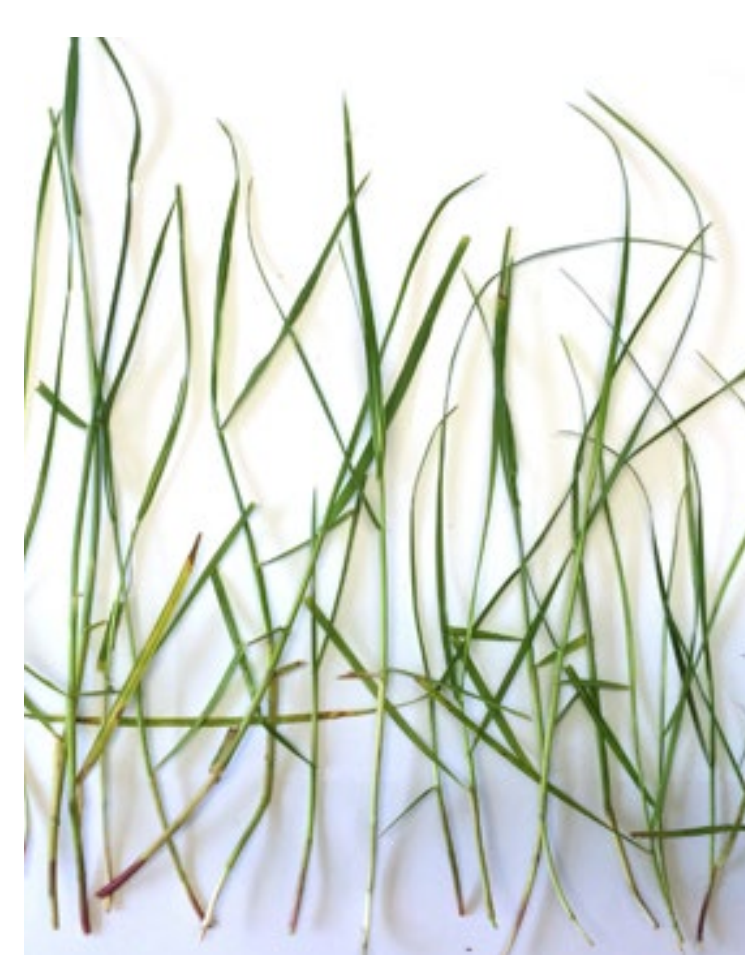

Grote spruiten, lange schijnstengels, veel bladschijf

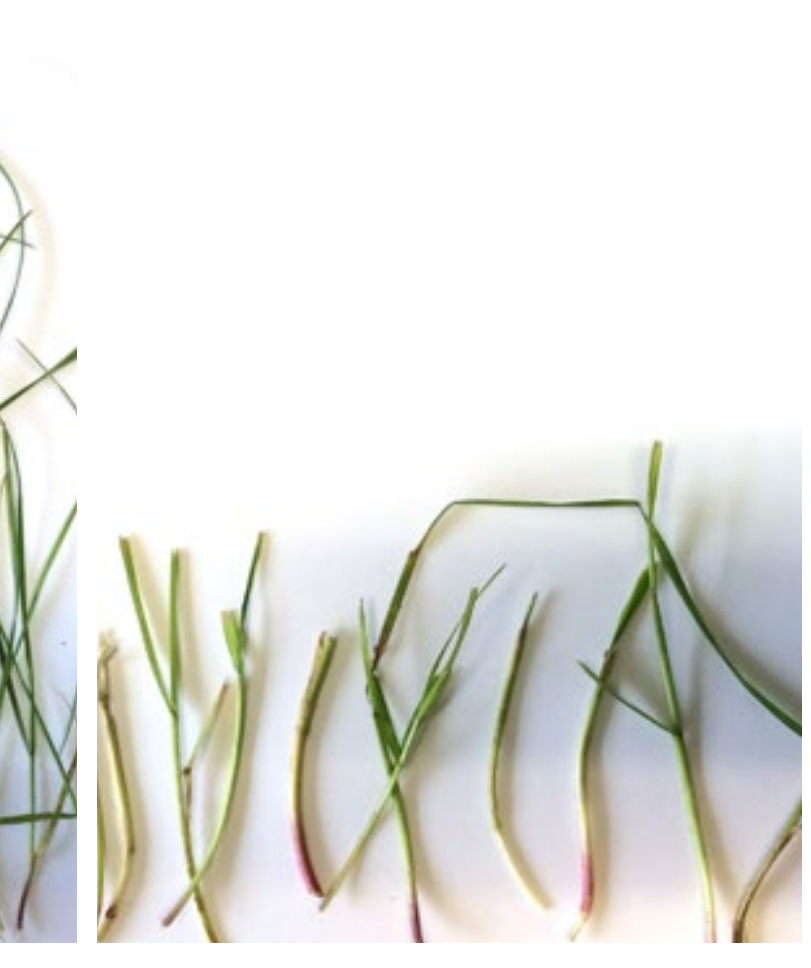

Grovere spruiten, weinig bladschiif

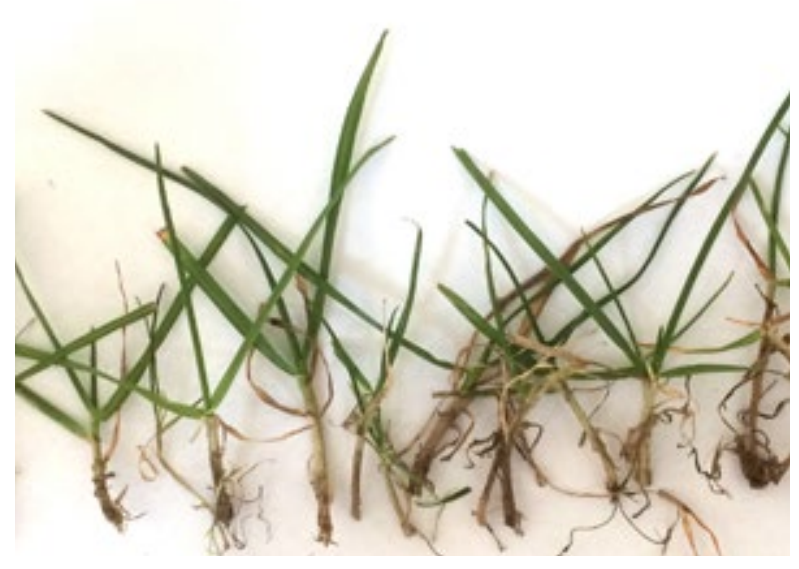

Fijne korte spruiten, relatief groot percentage bladschijven

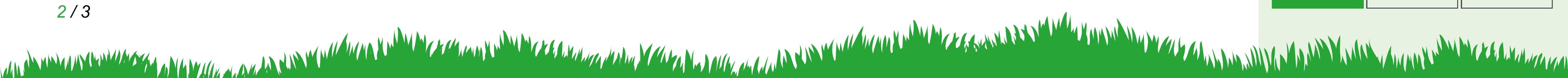


aanwezig. Bij stripgrazen moet de hergroe letterlijk uit de tenen komen. De hoeveelheid groen blad is na een beweiding zelfs minder dan bij kurzrazen. En de hoeveelheid bladschijf en schijnstengel zijn vrijwel gelijk. Uiteraard groeit het gras bij stripgrazen langer door zodat de reserves weer ruimschoots aangevuld kunnen worden.

\section{Dichtere zode}

De graszode bij Kurzrasen had een gemiddelde dichtheid van $80 \%$, terwijl die bij stripgrazen $60 \%$ was. De lagere groei van individuele grasspruiten bij Kurzrazen wordt dus deels gecompenseerd door de hogere zodedichtheid.

\section{Verder lezen in rapporten} van Amazing Grazing

- Hoekstra et al., 2019. The effect of kurzrasen and strip-grazing on grassland performance and soil quality of a peat meadow. Sustainability, 11(22), 6283.

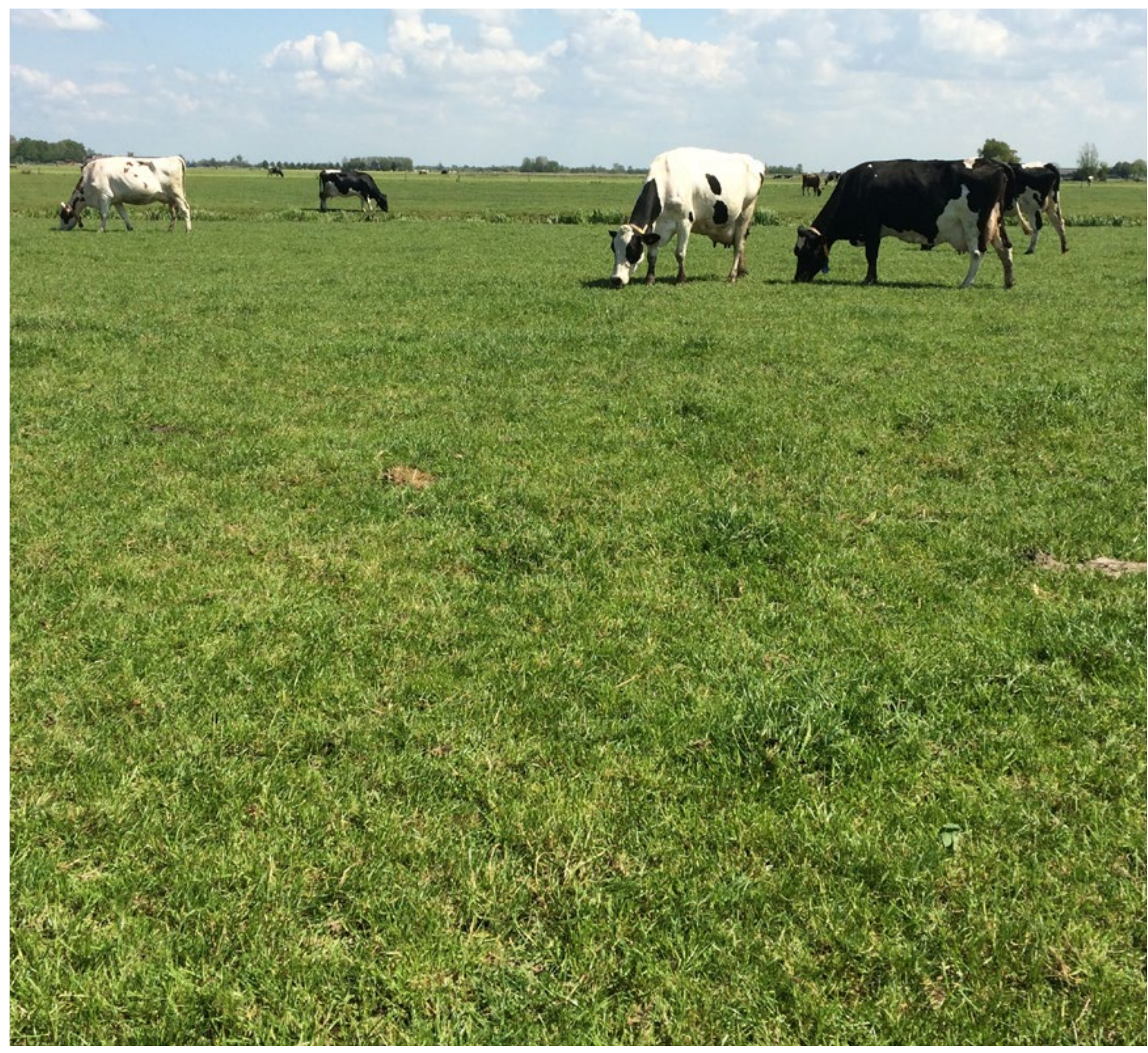

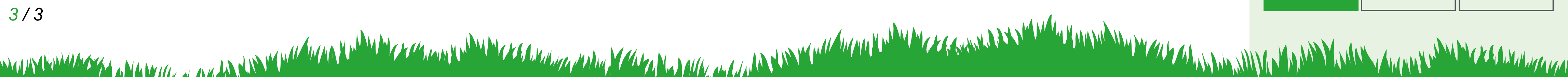

\section{Grasgroei}

- Hoe groeit gras

- Grasgroeimodel

- Hergroei na beweiding

- Kurzrasen: kort maar krachtig

- Grasgroei voorspellen

\begin{tabular}{|c|c|c|}
\hline \multicolumn{2}{|c|}{} \\
\hline \multicolumn{2}{|c|}{} \\
\hline Bijvoeding & Grasopname & Koegedrag \\
\hline Grasgroei & Bodem & Grasvoorraad \\
\hline
\end{tabular}




\section{Grasgroei voorspellen}

De korte-termijnplanning van graslandgebruik staat of valt met een goede voorspelling van de grasgroei. Dat lukt steeds beter, dankzij een slimme combinatie van een grasgroeimodel met weersvoorspelling.

De groei van gras is afhankelijk van veel verschillende factoren zoals zonnestraling, temperatuur, bodemtextuur, vocht, voorafgaand gebruik, beschikbaarheid van stikstof en graslandtype. Teveel eigenlijk om te kunnen overzien en rekening mee te houden. Om iets te kunnen zeggen over de groei in de komende week, maken we daarom meestal gebruik van gemiddelde waarden uit het verleden. Grasgroeimodellen kunnen echter wel rekening houden met een deel van de factoren die de grasgroei verklaren. In combinatie met een weersvoorspelling maakt een grasgroeimodel het mogelijk om veel specifiekere informatie te krijgen over de verwachte grasgroei in een bepaald gebied.

\section{Grasgroeimodel}

In Amazing Grazing gebruiken we een grasgroeimodel (GRAS2007) waarin het stikstofleverend vermogen (NLV) van de bodem, de bodemvochtbalans, de temperatuur, stikstofbemesting en voorafgaand graslandgebruik de belangrijkste factoren zijn die de grasgroei bepalen. De informatie over de bodem halen we uit de bodemkaart, terwijl we de informatie over temperatuur en neerslag uit de overzichten van

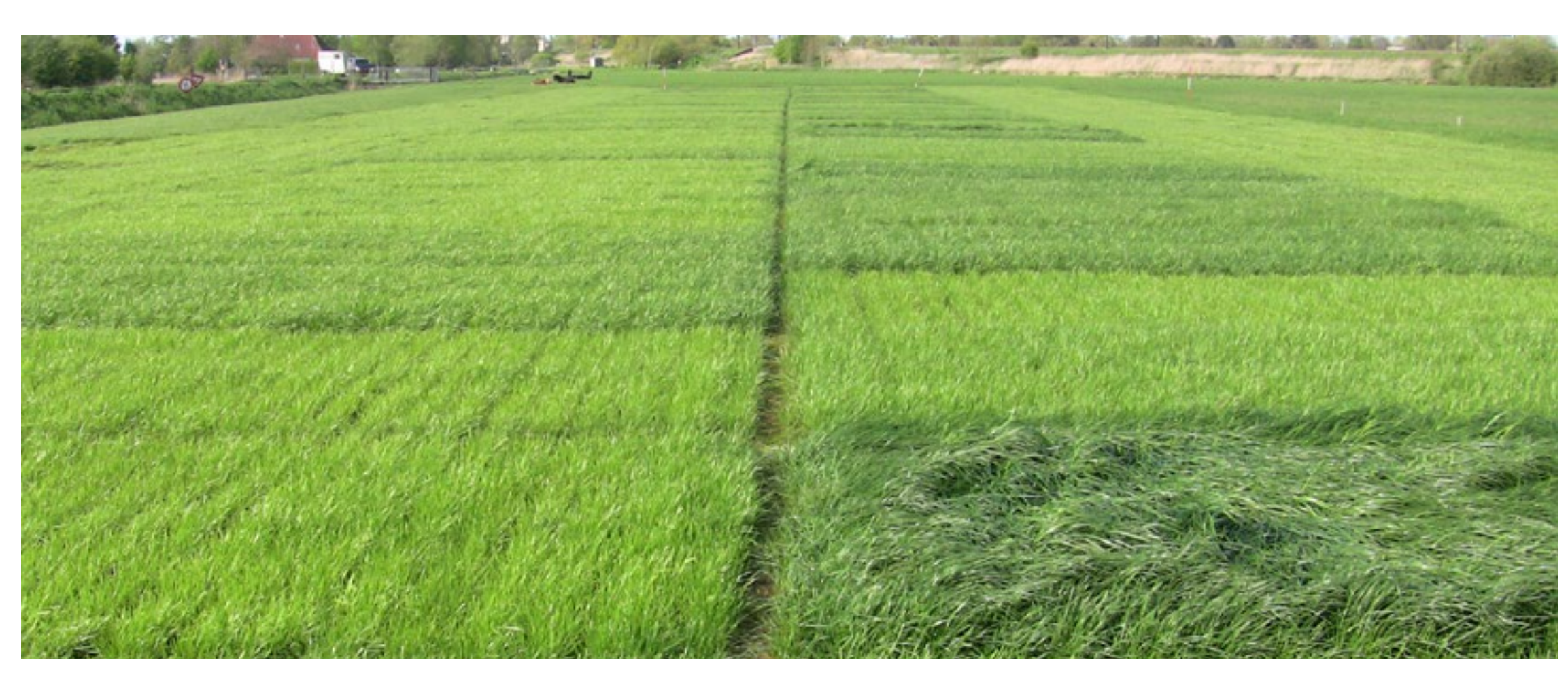

het gerealiseerde of voorspelde weer halen. Zelf vullen we de gegevens aan over bemesting en graslandgebruik.

\section{Voorspellen met gebruik van \\ weerverleden}

De voorspellingen van het grasgroeimodel, met behulp van het gerealiseerde weer,

$$
\text { Lees verder }
$$

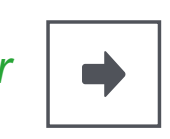

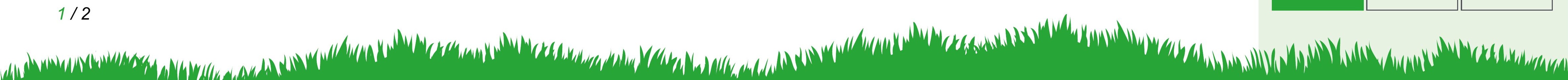


zijn in Amazing Grazing uitgebreid getoetst op drie locaties op zand, klei en veen.

Daaruit bleek dat er goede verbanden zijn tussen voorspelde en werkelijke opbrengsten, maar dat het model nog verdere verbetering behoeft. Gemiddeld genomen lukt de voorspelling op zandgrond beter dan op klei en veen vanwege de complexe waterhuishouding, onder andere vanwege de aanwezigheid van sloten, greppels en drainage. Voor alle grondsoorten geldt dat de uitkomsten gevoelig zijn voor het juist inschatten van het stikstofleverend vermogen. De werkelijke stikstoflevering varieert van jaar tot jaar en vertoont bovendien soms grote verschillen met de schatting op basis van een eenmalig grondmonster.

\section{Voorspellen met gebruik van} weersverwachting

Een stap verder is het gebruik van weersverwachting om de grasgroei in de komen- de dagen te voorspellen. Dat voegt uiteraard wel een extra onzekerheid toe die in de weersvoorspelling zelf zit. Die komt bovenop de onzekerheid van het grasgroeimodel. Deze werkwijze is ontwikkeld in de webapplicatie Grassignaal. Daarmee is voor drie locaties van Amazing Grazing de vijfdaagse groeivoorspelling berekend.

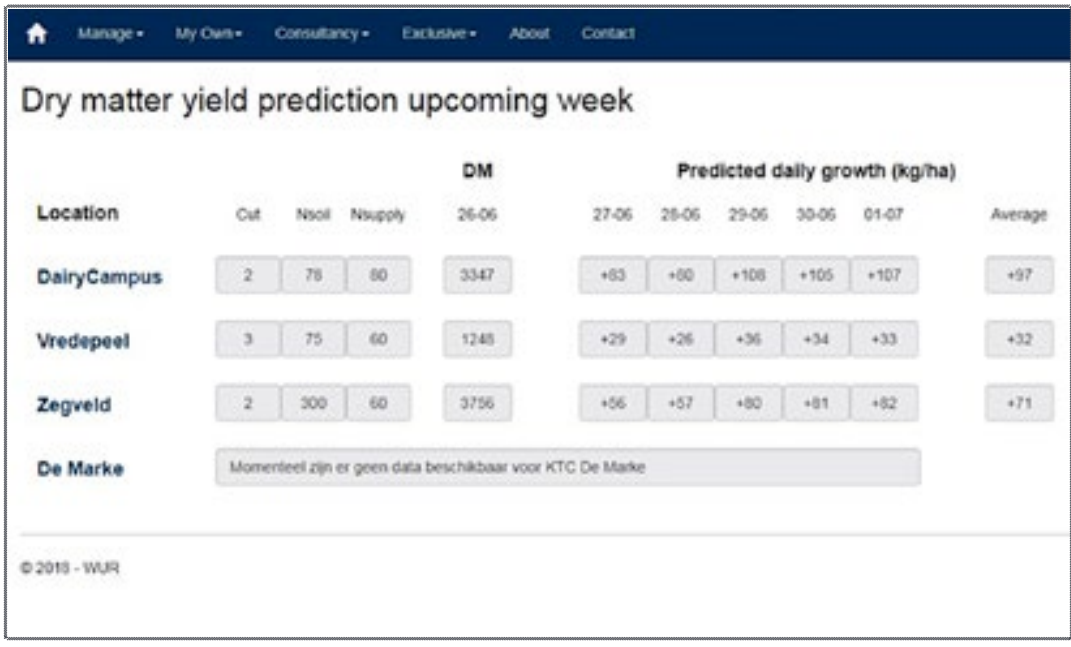

Screenshot van de webapplicatie GrasSignaal met een schatting van de actuele grasopbrengst en een voorspelling van de dagelijkse groei voor de weersverwachtingstermijn
Grasgroei

- Hoe groeit gras

- Grasgroeimode

- Hergroei na beweiding

Kurzrasen: kort maar krachtig

- Grasgroei voorspellen

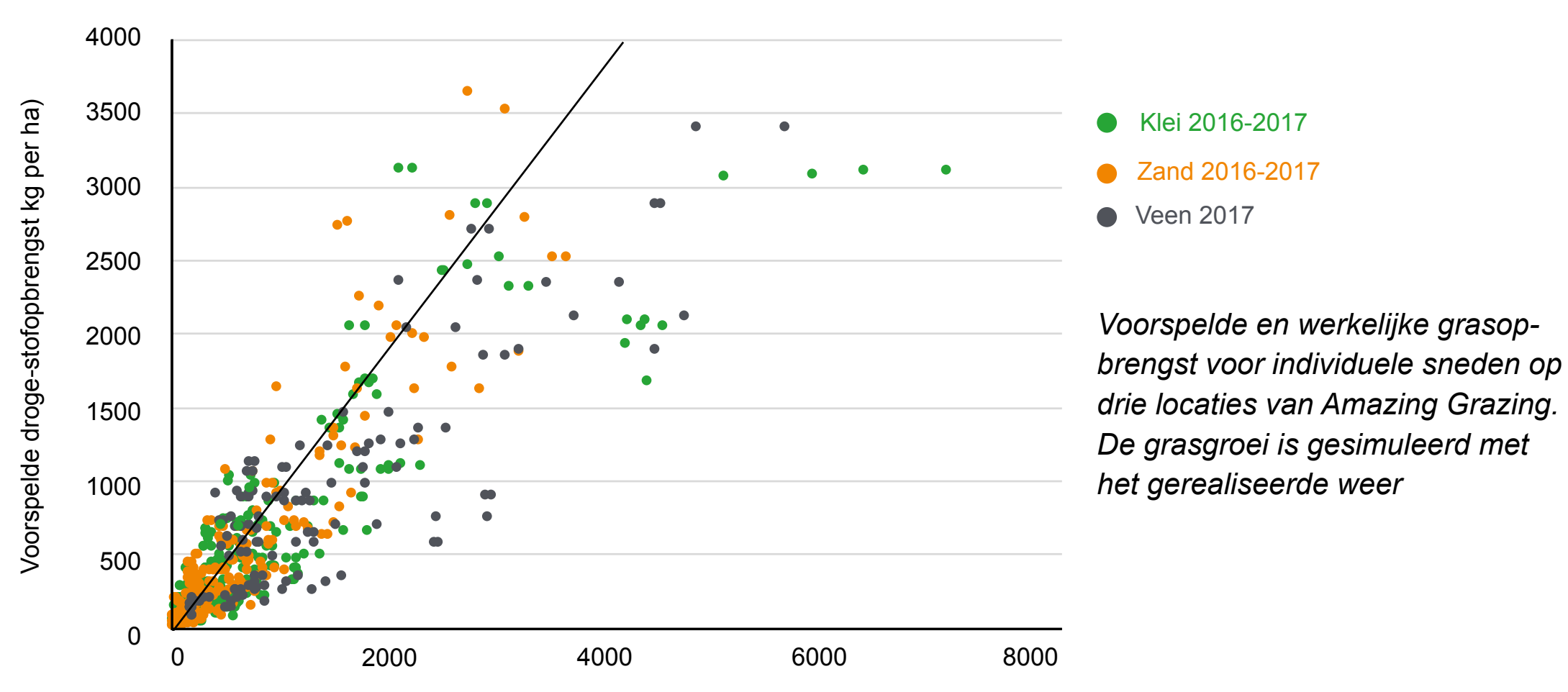

Werkelijke droge-stofopbrengst (kg per ha) 


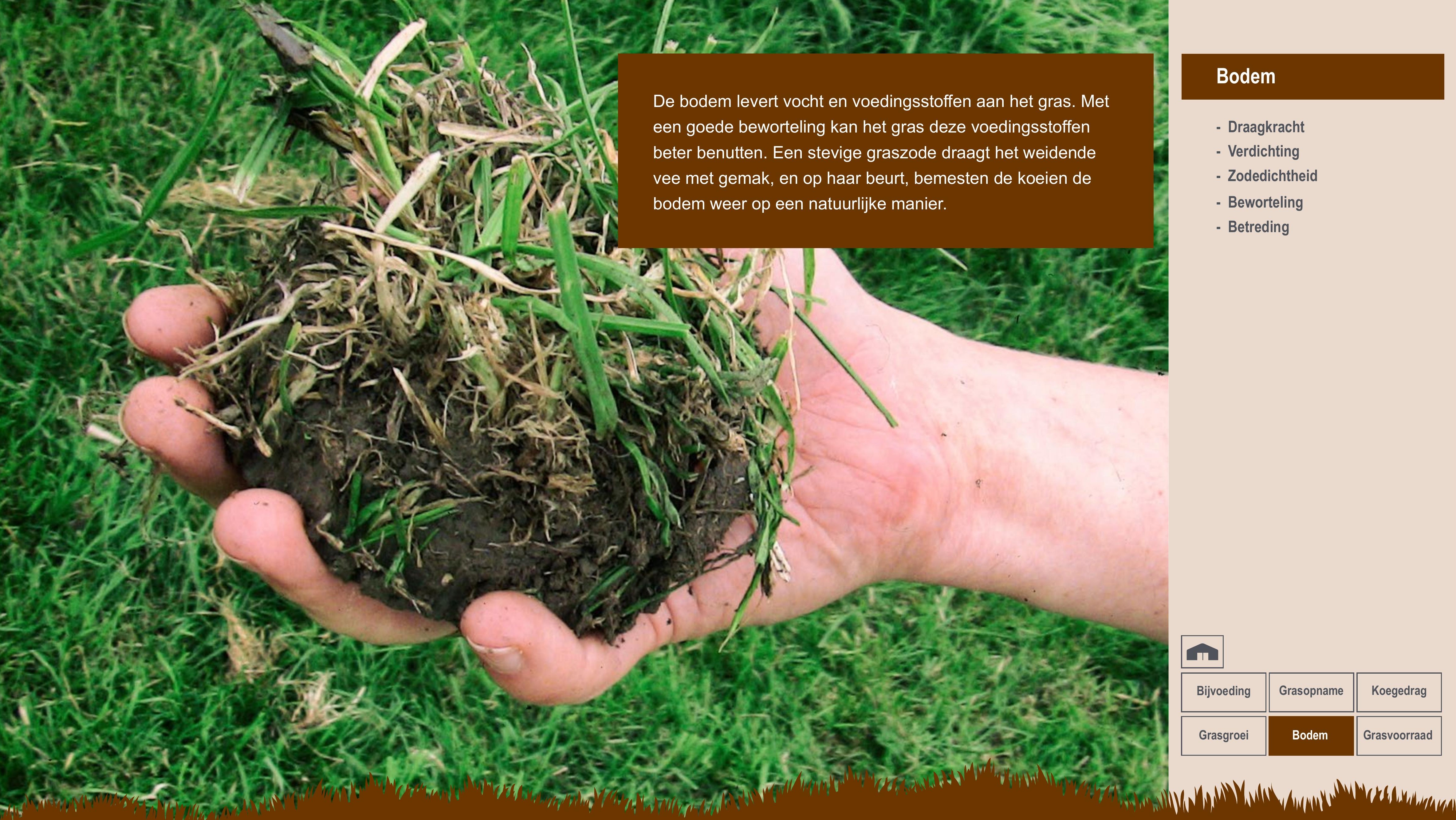




\section{Draagkracht}

De draagkracht van grasland is de weerstand die zode en bodem bieden tegen vervorming door druk van machines en weidend vee. Er kan nog zoveel gras op het land staan, een koe kan het alleen eten als het land beweid of gemaaid kan worden.

Draagkracht is de maximale indringingsweerstand van een penetrometer met een conus van $5 \mathrm{~cm}^{2}$ met een tophoek van $60^{\circ}$ in de bovenste vijf centimeter van de zode. Als vuistregel geldt dat de draagkracht voldoende is boven een indringingsweerstand van 0,5 MPa. Het is goed mogelijk dat de zode enkele centimeters wordt ingedrukt, als je er maar niet te makkelijk doorheen gaat. De interpretatie van draagkrachtmetingen vergt wel enige oplettendheid, omdat de indringingsweerstand afhankelijk is van het vochtgehalte in de bodem. Draagkrachtmetingen zijn vooral

Lees verder digheden, als draagkracht een beperkende factor lijkt te worden.

\section{Gebruik afstemmen op draagkracht}

Naast het vochtgehalte zijn textuur, organische stofgehalte en zodekwaliteit van belang voor de draagkracht. Hoe lager de gehalten aan vocht, organische stof en klei, hoe hoger de draagkracht. Dichte, goed gewortelde graszoden hebben een betere draagkracht dan open zoden.

Het ligt voor de hand dat het verstandig is om het gebruik van een perceel af te stemmen op de actuele draagkracht. Vermijd weiden en maaien als de draagkracht het niet toelaat. Of denk aan aanpassingen zoals een kortere weidetijd of lagere bandenspanning

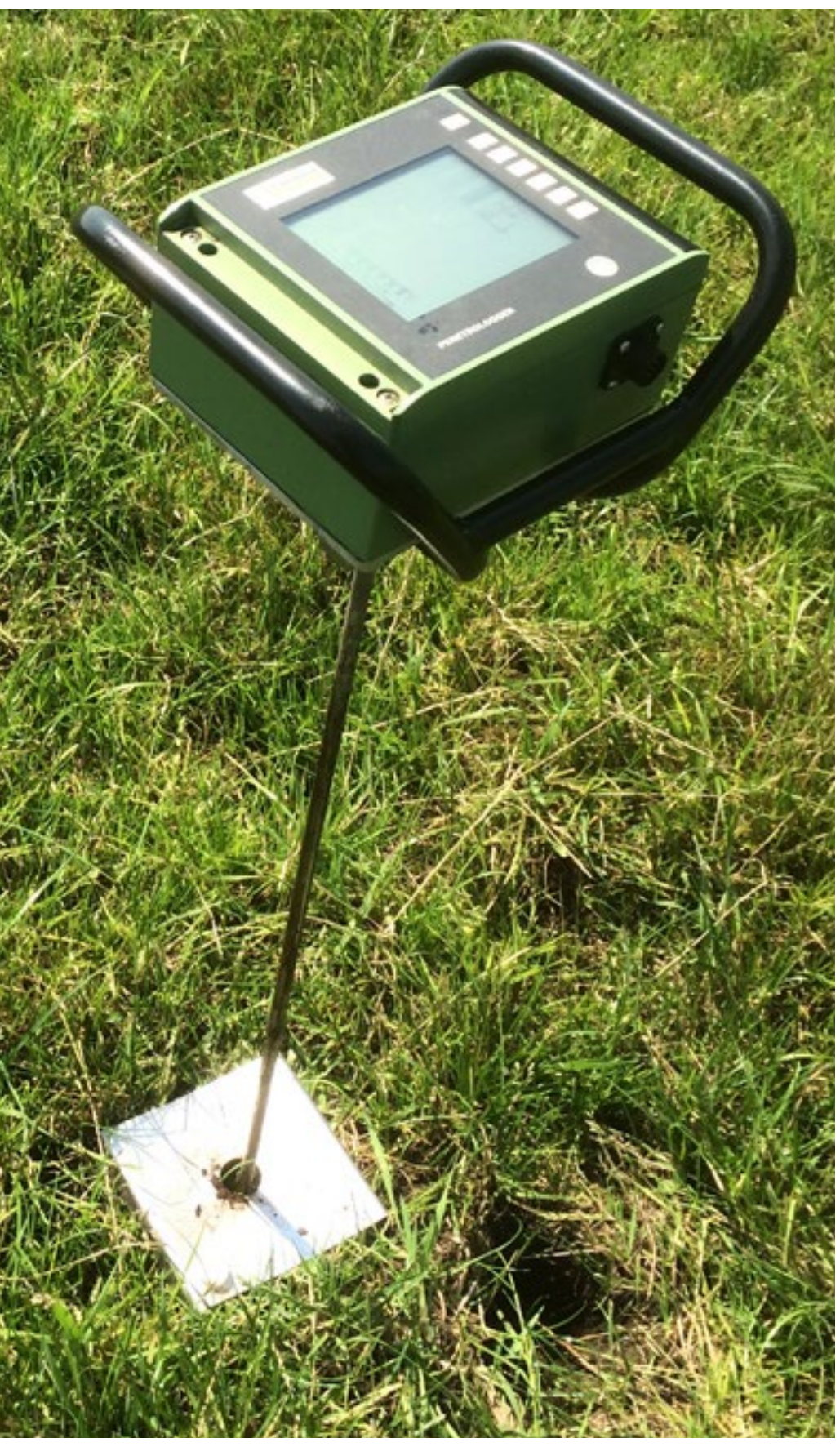

Penetrometer voorzien van een conus van $5 \mathrm{~cm}^{2}$ met een tophoek van $60^{\circ}$
Bodem

- Draagkracht

- Verdichting

- Zodedichtheid

- Beworteling

- Betreding

\begin{tabular}{|c|c|c|}
\hline Bijvoeding & Grasopname & Koegedrag \\
\hline \hline Grasgroei & Bodem & Grasvoorraad \\
\hline
\end{tabular}




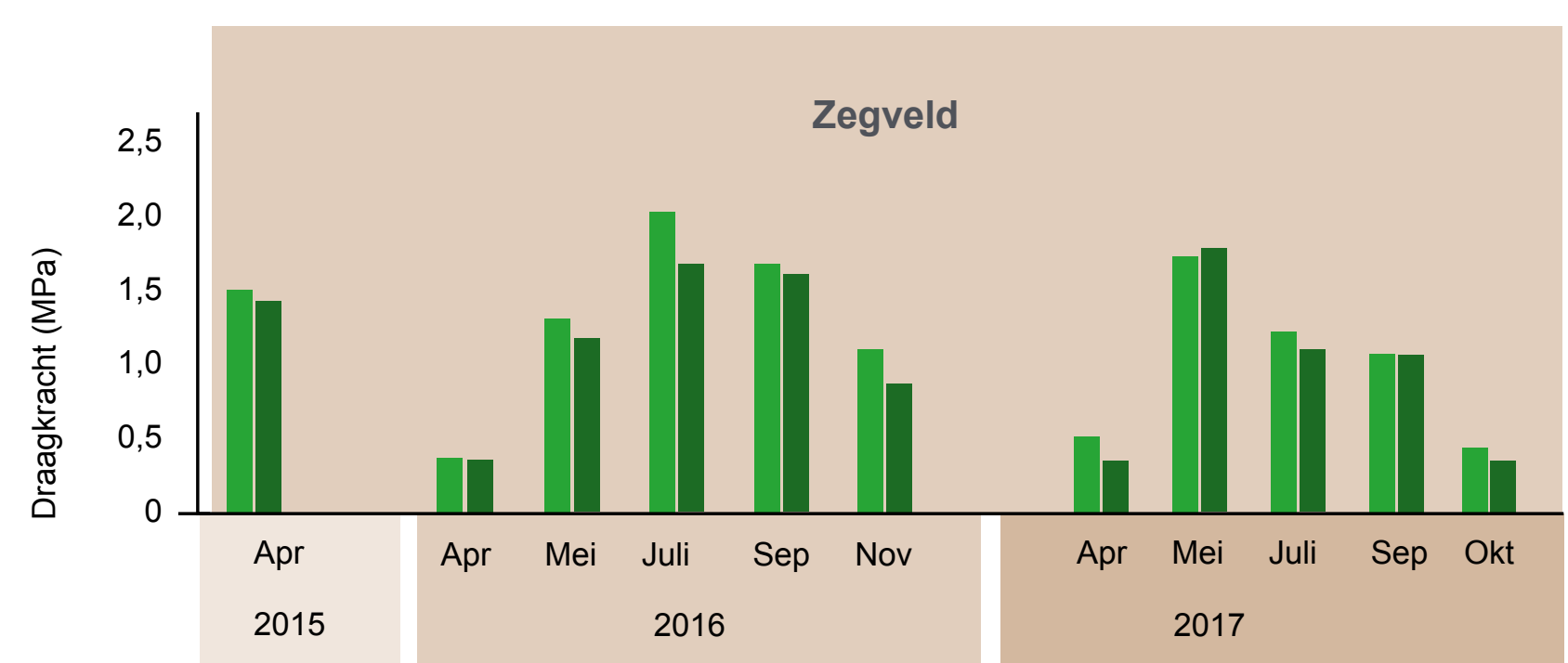

Kurzrasen

Stripgrazen

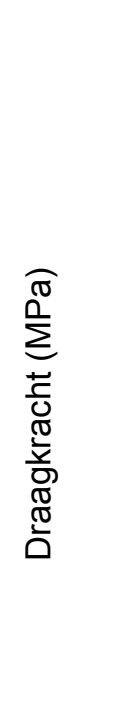

\begin{tabular}{l|}
4,5 \\
4,0 \\
3,5 \\
3,0 \\
2,5 \\
2,0 \\
1,5 \\
1,0 \\
0,5 \\
0
\end{tabular}

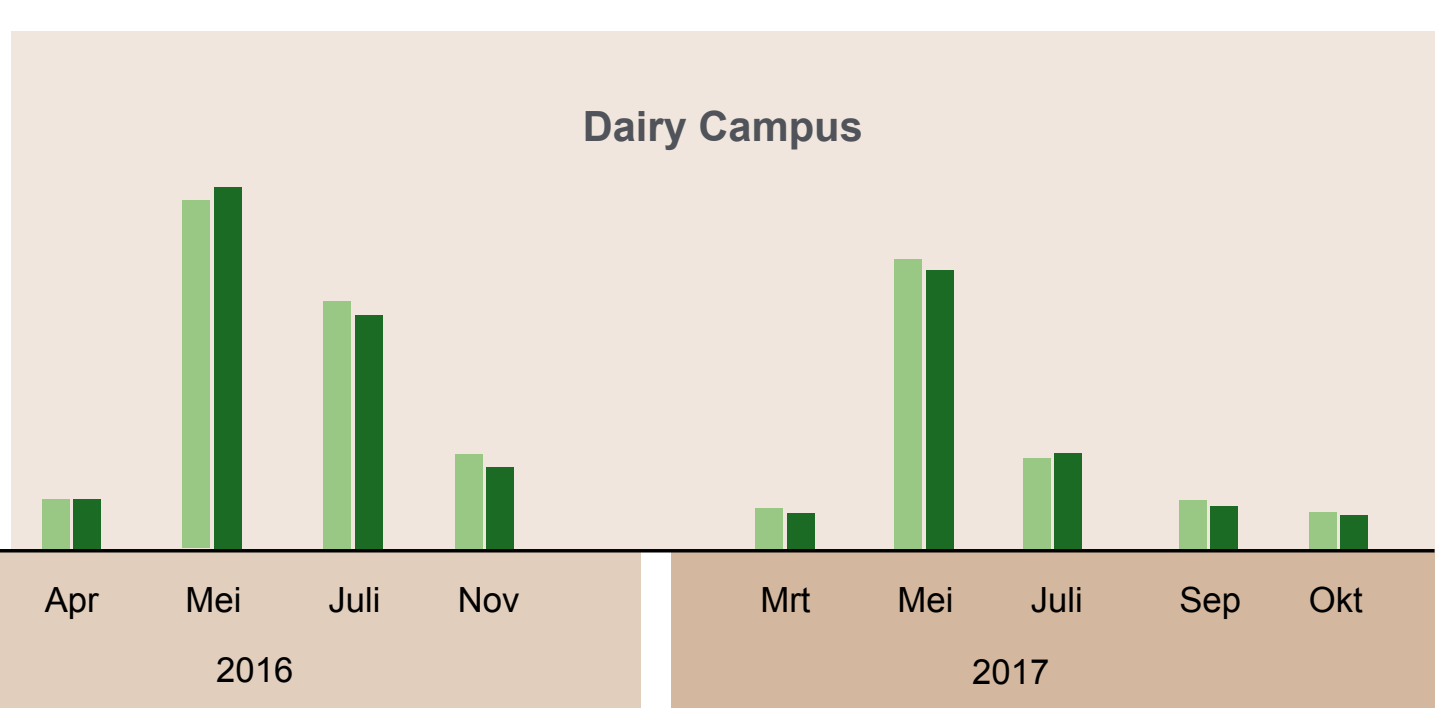

Roterend standweiden

Stripgrazen

Verloop van de draagkracht in de beweidingsproeven van Amazing Grazing op veen (Zegveld) en klei (Dairy Campus)

\section{Draagkracht verbeteren}

Is het ook mogelijk om de draagkracht structureel te verbeteren? Die speelruimte ligt vooral bij ontwatering en zodekwaliteit. De mogelijkheden zijn afhankelijk van de specifieke situatie; op veengrond is onderwaterdrainage een geschikte maatregel. De zodekwaliteit is vooral te sturen door het graslandgebruik en de leeftijd van het grasland, en wellicht ook door de keuze van grassoorten. In de beweidingsproeven van Amazing Grazing op veen is de draagkracht bij kurzrasen beter dan bij stripgrazen. Dit lijkt samen te hangen met de hogere zodedichtheid onder kurzrasen, maar ook met de iets drogere bodem onder kurzrasen. Op kleigrond waren er geen consistente verschillen tussen standweiden en stripgrazen.

\begin{tabular}{|c|c|c|}
\hline \multicolumn{2}{|c|}{} \\
\hline Bijvoeding & Grasopname & Koegedrag \\
\hline Grasgroei & Bodem & Grasvoorraad \\
\hline
\end{tabular}




\section{Verdichting}

Weidende koeien verdichten de toplaag van de bodem. Onder natte omstandigheden kan bovendien vertrapping optreden. Wat betekent dat voor de grasgroei?
Bodemverdichting gaat gepaard met een afname van het aandeel poriën. Vooral de macroporiën, groter dan $0,1 \mathrm{~mm}$, zijn kwetsbaar voor verdichting. Dat heeft directe gevolgen voor de lucht- en waterhuishouding. Het spreekt voor zich dat de bodem door de afname van het aandeel poriën minder lucht en zuurstof kan bevat- ten, waardoor de groei van wortels wordt geremd. De invloed van verdichting op de waterhuishouding is echter ingewikkelder Enerzijds nemen de waterdoorlatendheid en infiltratiecapaciteit af, waardoor water moeilijker van boven naar beneden

Lees verder

\section{Bodem}

- Draagkracht

- Verdichting

- Zodedichtheid

- Beworteling

- Betreding

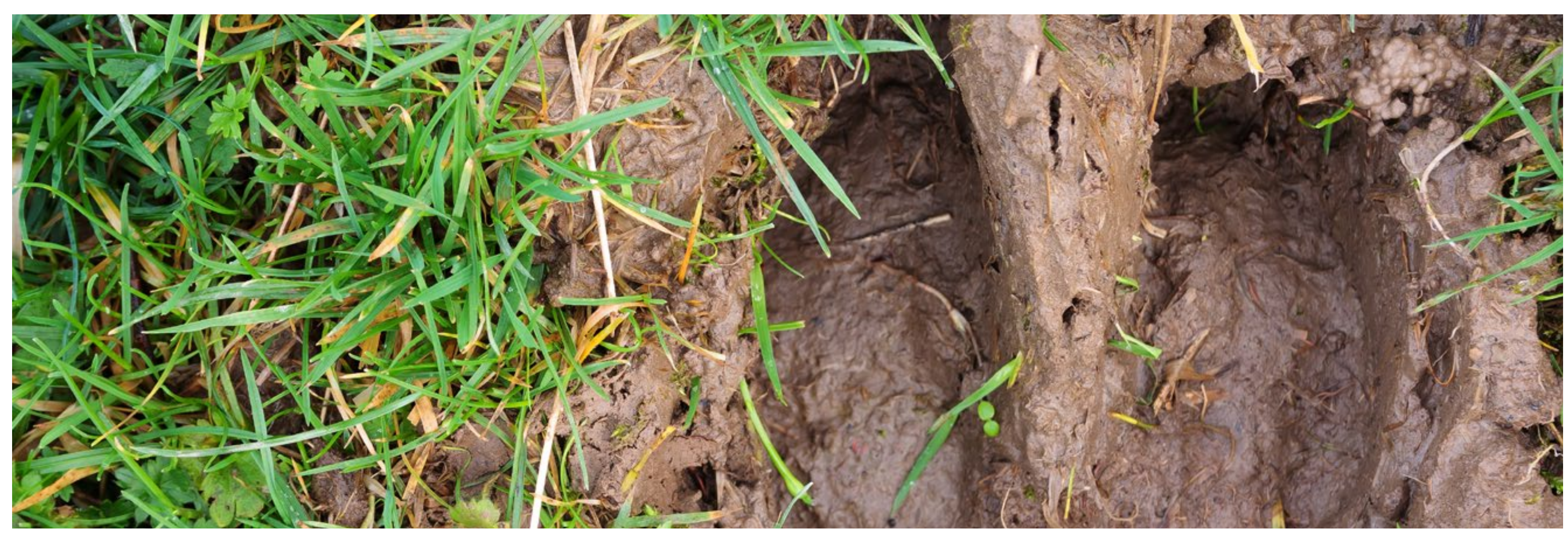


beweegt. Bij wateroverlast blijt de grond dus langer nat. Anderzijds neemt de capillaire levering juist toe, waardoor water makkelijker van beneden naar boven beweegt. Bij droogte levert dat extra vocht voor de plant.

\section{Groei van graswortels}

Bodemverdichting beïnvloedt de groei van graswortels op verschillende manieren.

Naarmate het aantal en de grootte van de poriën afneemt, wordt het voor de hoofdwortels moeilijker om ongestoord te groeien. De hoofdwortels gaan zich bij verdichting weliswaar sterker vertakken in kleinere zijwortels die wel nog in de kleinere poriën kunnen doordringen. Toch is deze compensatie niet voldoende, omdat het aantal aaneengesloten poriën afneemt bij verdichting.

Er zijn verschillende drempelwaarden in omloop waarboven de wortelgroei wordt geremd. Voor planten in het algemeen geldt een indringingsweerstand van 2 tot 3 MPa (20 tot 30 bar) als drempelwaarde, maar voor grassen worden ook wel wat hogere waarden genoemd vanwege de fijnere wortels. De positieve keerzijde van verdichting is dat het aantal gronddeeltjes per eenheid volume toeneemt, waardoor het contactoppervlak tussen wortels en grond toeneemt. Dat kan gunstig zijn voor de opname van sommige minder beweeglijke voedingsstoffen zoals fosfaat.

\section{Opbrengstderving door berijding}

Terwijl voor bouwland vrij duidelijke relaties zijn aangetoond tussen bodemverdichting en lagere gewasopbrengsten, is dat bij grasland minder duidelijk. Over het algemeen bestaat wel het beeld dat veel graslandpercelen in meer of mindere mate verdicht zijn, maar dat wordt vooral toegeschreven aan verdichting van de ondergrond door berijding. In Nederlands onderzoek naar de effecten van berijding op grasland op zandgrond zijn opbrengstdervingen tot $12 \%$ gevonden door hogere bodembelasting. Echter, ook opbrengststijgingen zijn gevonden, mogelijk veroorzaakt door een betere vochtvoorziening.

\section{Opbrengstderving door beweiding}

De invloed van verdichting door beweiding is in Nederland nooit onderzocht. Buitenlandse studies, met name op gras/klaver mengsels in Nieuw Zeeland en Australië, laten opbrengstdervingen zien tot $22 \%$. Deze cijfers gelden voor de invloed van betreding, maar zonder vertrapping. In speciale vertrappingsstudies zijn beweidingen uitgevoerd met hoge veebezettingen tot wel 600 koeien per ha, onder natte omstandigheden. De opbrengstdervingen door vertrapping liepen uiteen van 7 tot $88 \%$.

- Draagkracht

- Verdichting

Zodedichtheid

- Beworteling

Betreding

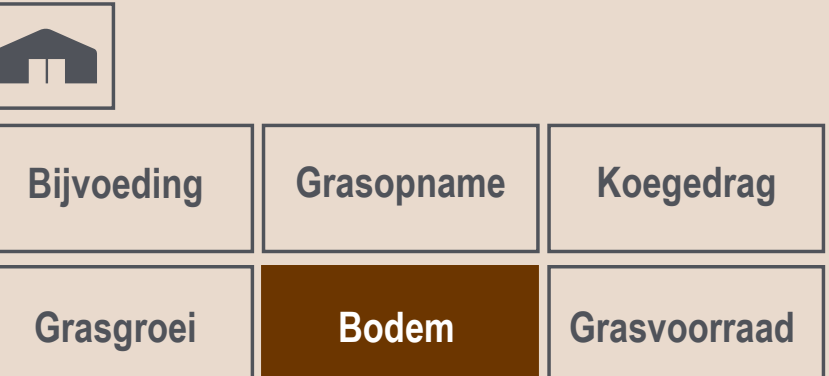




\section{Zodedichtheid}

De zodedichtheid is belangrijk voor de draagkracht van de zode en het productievermogen van het gras. Een dichte zode met goede grassen helpt bovendien om ongewenste grassen en onkruiden uit de zode te houden.

Het aantal spruiten in grasland varieert meestal tussen de 50 en 200 spruiten per $\mathrm{dm}^{2}$. Hogere dichtheden zijn zeker niet uitgesloten, bijvoorbeeld in graszoden met veel kleinere grassoorten of onder beweiding met schapen. Andersom zijn lagere dichtheden mogelijk als grasland heeft geleden onder droogte, of na lange groeiperioden in combinatie met hoge stikstofgiften.

\section{Zode is dichter bij beweiding}

De dichtheid van de zode reageert sterk op het graslandgebruik, al hoeft dat niet direct zichtbaar te zijn. Over het algemeen is de zode bij beweiding dichter dan bij

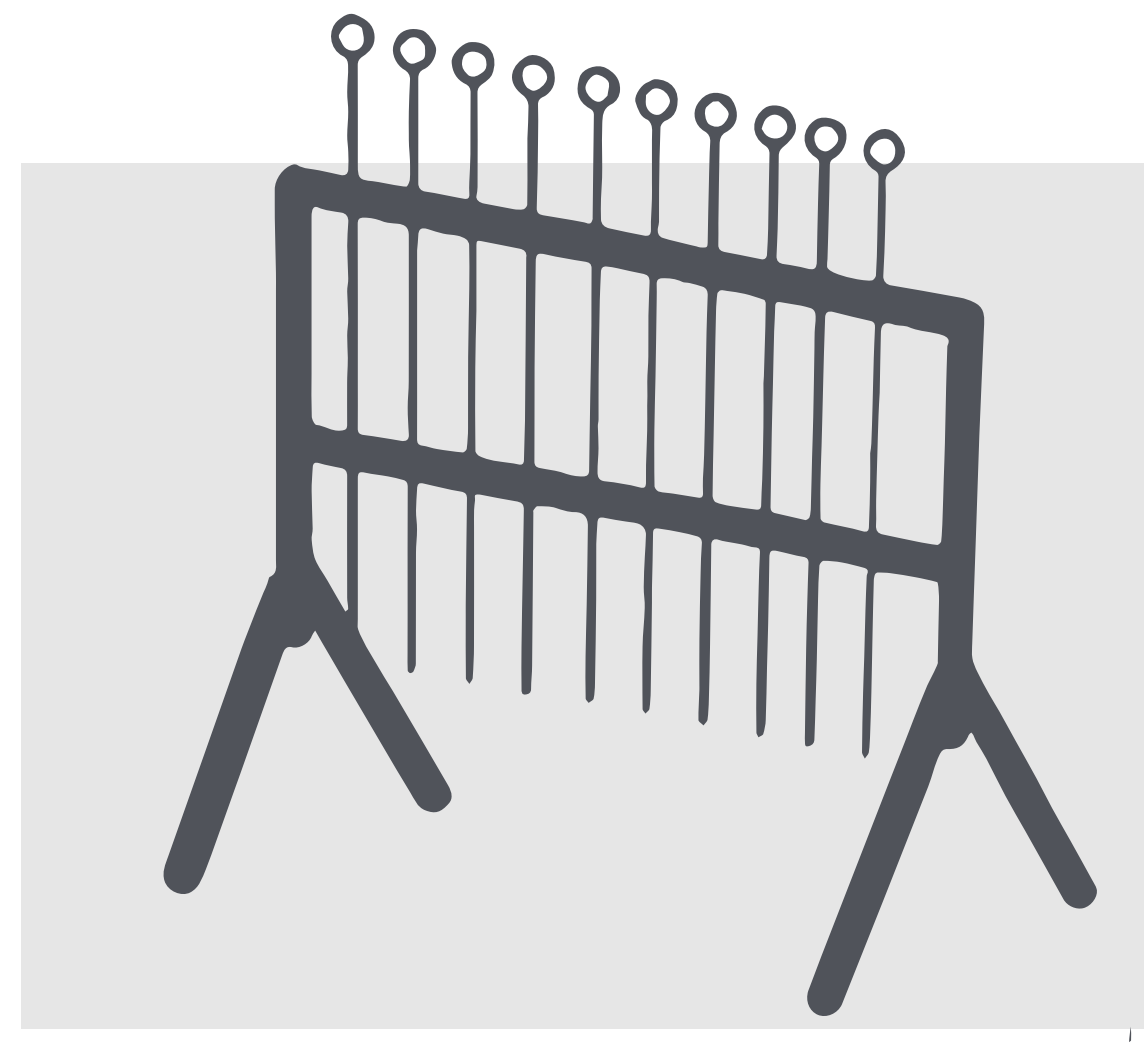

maaien. Dat komt doordat het gras bij beweiding korter en vaker wordt ontbladerd dan bij maaien. Bij beweiding is dus minder schaduwwerking tussen de onderlinge grasplantjes, wat de vorming van nieuwe spruiten bevordert. De dichtheid van de zode varieert bovendien met het seizoen.

Ze neemt af als het gras in de maanden mei en juni in bloei staat. De grasplant investeert dan meer in de stengels en bloemen dan in de vorming van nieuwe spruiten.
De zodedichtheid is gemeten met de point quadrat methode. Bij deze methode worden tien spaken met $10 \mathrm{~cm}$ afstand in de grond geprikt en wordt op grondniveau gekeken of de spaken kale grond raken of de basis van een grasspruit. Deze meting is twintig keer herhaald voor elk beweidingssysteem en gebruikt om het percentage bedekking door gras op grondniveau te berekenen.

Bodem

- Draagkracht

- Verdichting

- Zodedichtheid

Beworteling

Betreding

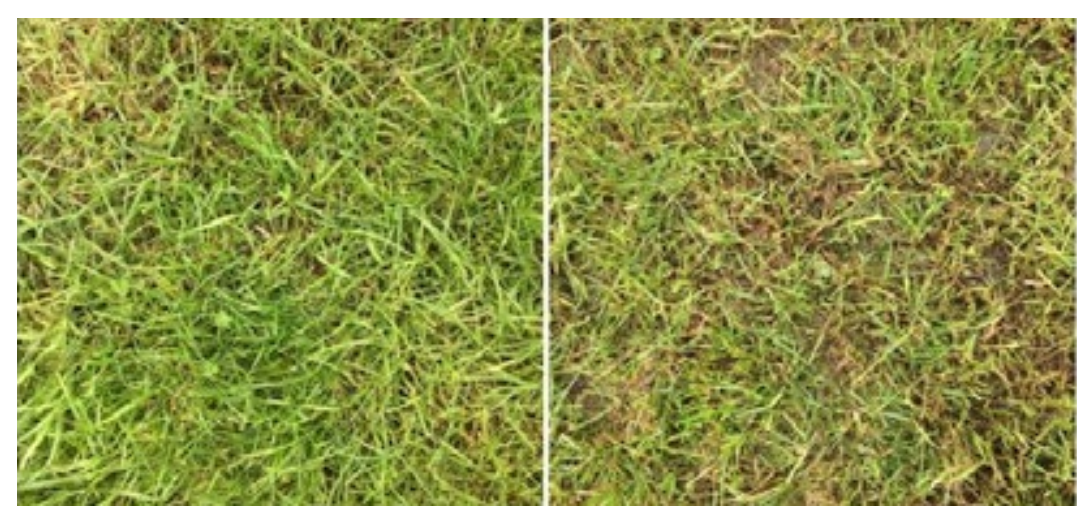

Hogere zodedichtheid onder roterend standweiden (links) vergeleken met stripgrazen (rechts) op Dairy Campus in september 2017

Lees verder

\begin{tabular}{|c|c|c|}
\hline Bijvoeding & Grasopname & Koegedrag \\
\hline Grasgroei & Bodem & Grasvoorraad \\
\hline
\end{tabular}




\section{Beworteling}

Grassen hebben een uitgebreid en fijnmazig wortelstelsel. Daarmee voorzien ze de plant van water en voedingsstoffen. Maar graswortels doen meer; ze zijn belangrijk voor het vastleggen en afbreken van bodemkoolstof en -stikstof, en in het voorkomen van erosie.

Als de bodem het toelaat, kunnen de wortels van grasland tot wel meer dan twee meter diep reiken. In Nederlandse graslanden vinden we de meeste wortels echter in de bovenste $30 \mathrm{~cm}$. De effectieve bewortelingsdiepte komt overeen met de zone waarin zich meer dan 80 tot 90 procent van de wortels bevindt. Door zelf een profielkuil te graven is het vrij makkelijk om een indruk te krijgen van de bewortelingsdiepte onder de eigen percelen. Op zandgrond kun je de effectieve bewortelingsdiepte schatten door tijdens een droge periode te bekijken tot welke diepte de grond leeggetrokken is door waterverdam- ping. Maar het draait niet om diepte alleen. Het totale wortelgewicht en de worteldichtheid zijn ook belangrijk, maar wel moeilijker te meten.

\section{Wortelgroei}

Tijdens de vegetatieve groei is, bij gelijkblijvende omstandigheden, de verhouding tussen ondergrondse wortels en bovengrondse stengels en bladeren redelijk stabiel. Na ontbladering door beweiding of maaien wordt die balans tijdelijk verstoord. De hergroei van gras gaat in eerste instantie ten koste van de energiereserves in de wortels. De wortelgroei stopt dan tijdelijk, en wortels sterven zelfs af. Als na enige tijd voldoende blad is gevormd, beginnen de wortels ook weer te groeien. Vanwege dit wisselende proces van groei en afbraak is het belangrijk om een duidelijk onderscheid te maken tussen de totale bruto wortelgroei en het wortelgewicht op een

$$
\text { Lees verder }
$$

Bodem

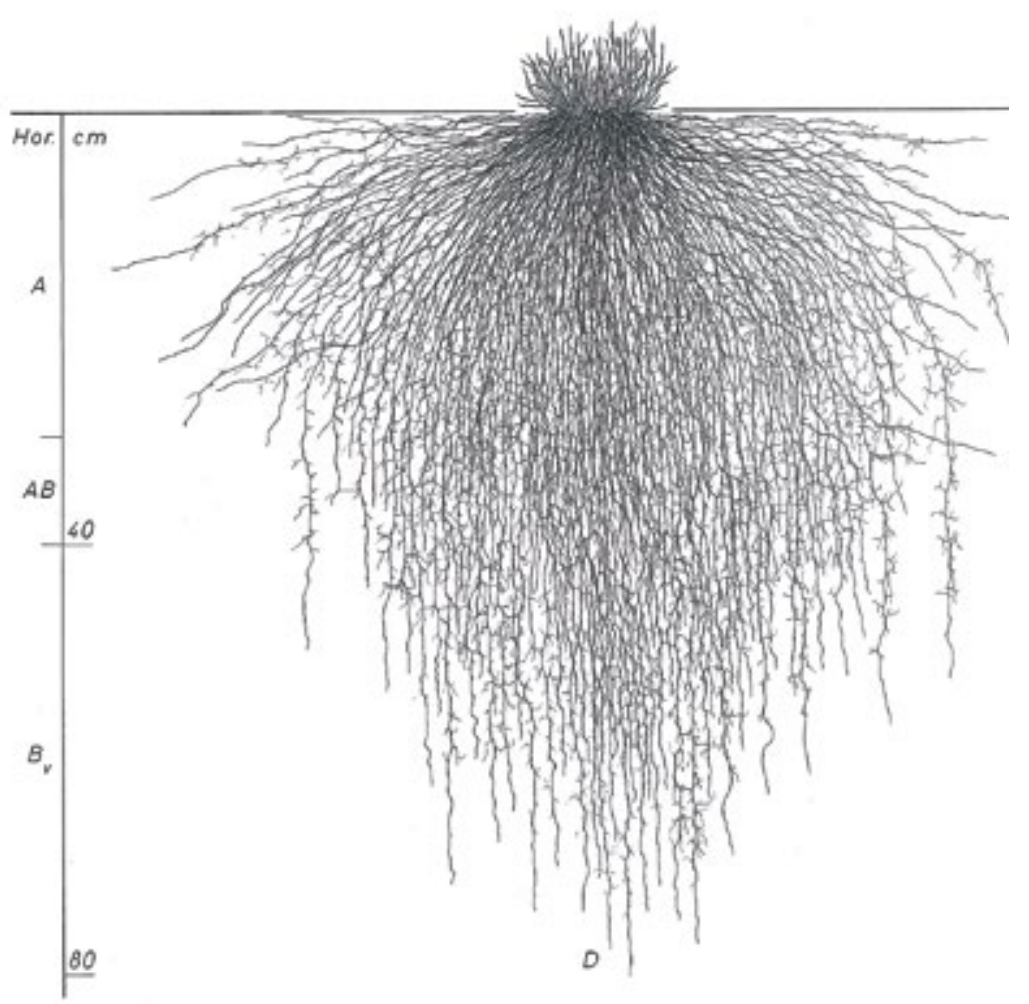

Wortelstelsel van Engels raaigras, ongeveer een jaar na inzaai (Kutschera et al., 1982)

\begin{tabular}{|c|c|c|}
\hline Bijvoeding & Grasopname & Koegedrag \\
\hline Grasgroei & Bodem & Grasvoorraad \\
\hline
\end{tabular}


bepaald moment in het jaar. Grofweg geldt dat de wortels twee keer per jaar worden vernieuwd. Dat betekent bijvoorbeeld dat bij een gemiddeld aanwezig wortelgewicht van 3 ton droge stof per ha, de totale bruto groei wel 6 ton droge stof per ha per jaar bedraagt. De spreiding in deze cijfers is groot omdat er ook studies zijn waaruit blijkt dat de jaarlijkse wortelvernieuwing veel hoger kan zijn.

\section{Worteldichtheid}

De worteldichtheid is een maat voor doorworteling van de grond. Een hogere worteldichtheid heeft mogelijk een positief effect op de opname van voedingsstoffen.
Dat geldt vooral voor minder beweegbare stoffen zoals fosfaat. Voor Engels raaigras ligt de wortellengtedichtheid rond de $20 \mathrm{~cm}$ per $\mathrm{ml}$ grond. Lees verder $\Rightarrow$
Bodem

- Draagkracht

- Verdichting

- Zodedichtheid

- Beworteling

- Betreding
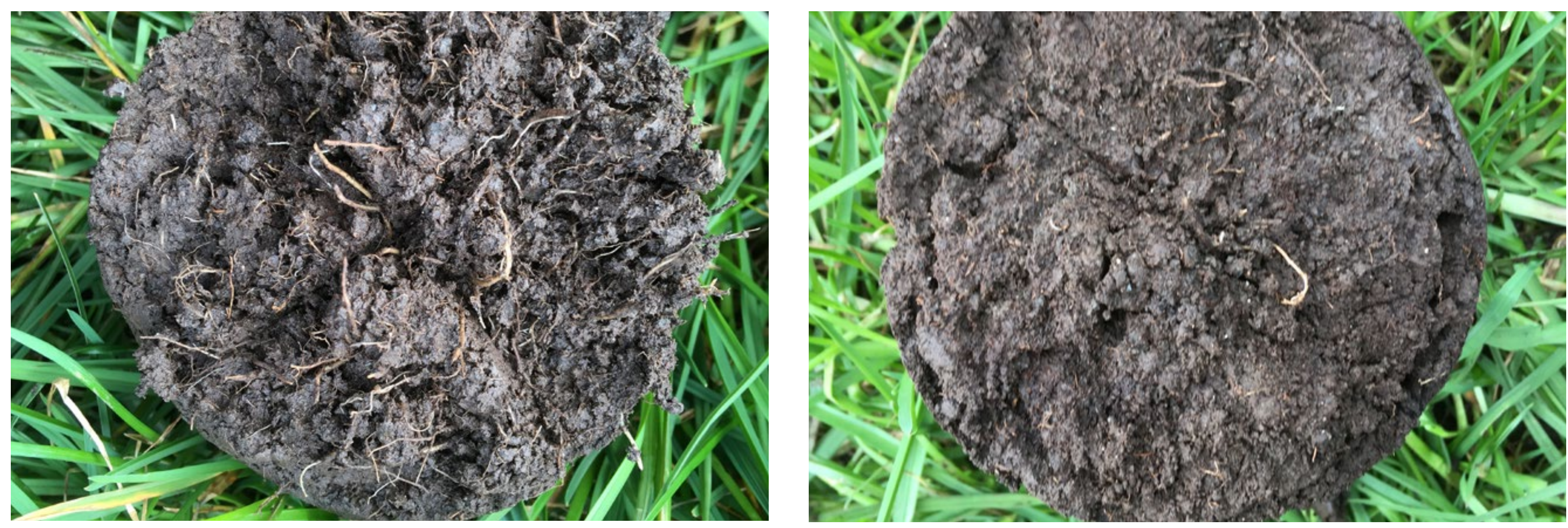

Wortels op 10 en $20 \mathrm{~cm}$ diepte in maart 2018 op veengrond (Zegveld)

\begin{tabular}{|c|c|c|}
\hline Bijvoeding & Grasopname & Koegedrag \\
\hline \hline Grasgroei & Bodem & Grasvoorraad \\
\hline
\end{tabular}

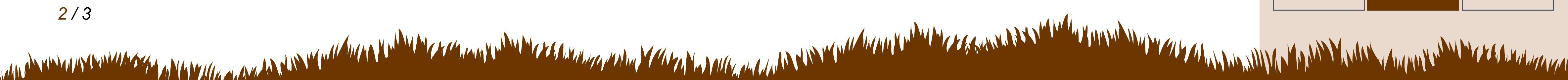



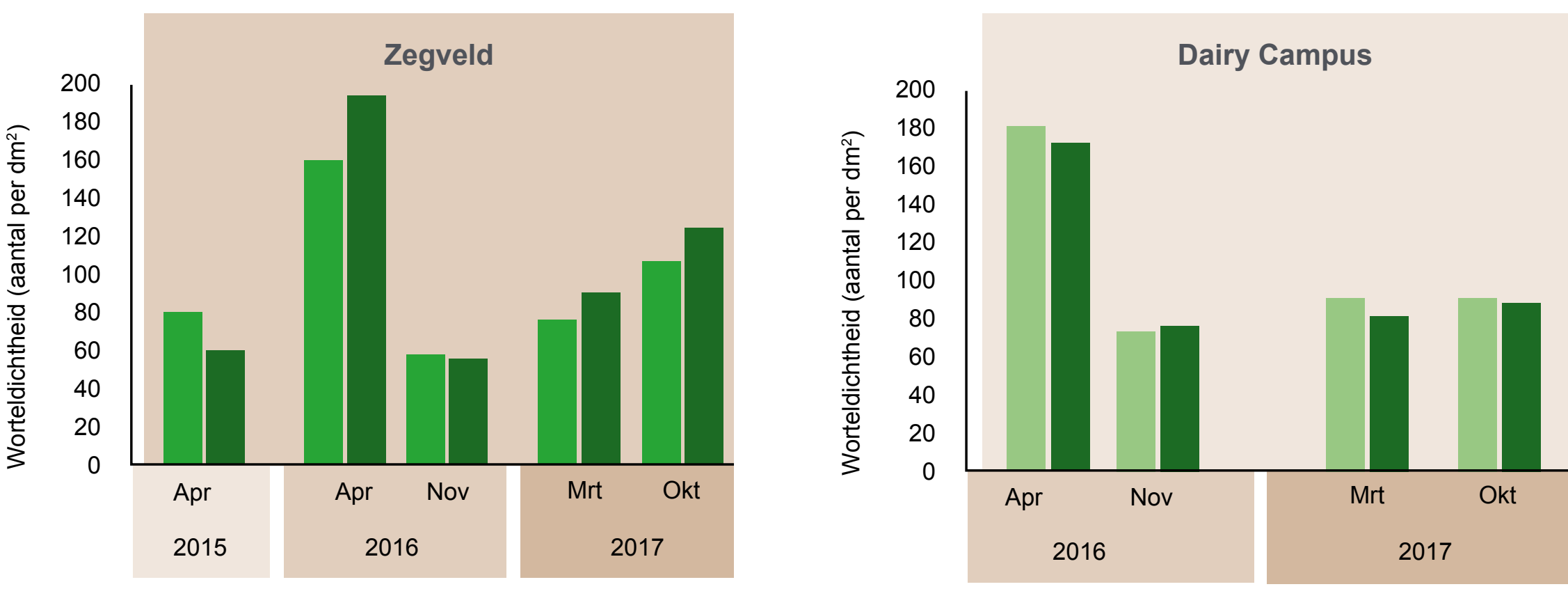

Kurzrasen
Roterend standweiden

Stripgrazen

Verloop van de beworteling tot $20 \mathrm{~cm}$ in de beweidingsproeven van Amazing Grazing op veen (Zegveld) en klei (Dairy Campus). De meting in het voorjaar van 2015 op Zegveld en het voorjaar van 2016 op Dairy Campus is de uitgangssituatie bij de start van het onderzoek. De worteldichtheid is gemeten door het aantal wortels te tellen per $\mathrm{dm}^{2}$

\section{Bewortelingsdiepte}

De beworteling van grasland is afhankelijk van de leeftijd van de zode, oogstfrequentie, bemesting, ingezaaide soorten en rassen en natuurlijk de eigenschappen van de bodem. De beworteling van jong grasland lijkt wel wat op die van granen en kan dus wel tot ruim een meter diep gaan. In de loop van de tijd neemt de bewortelingsdiepte af. Meer dan $80 \%$ van de wortels bevindt zich dan doorgaans in de bovenste $30 \mathrm{~cm}$. Het komt zelfs regelmatig voor dat bij Engels raaigras wel 80 tot $90 \%$ in de bovenste 20 , of zelfs $10 \mathrm{~cm}$ zit. De bodem kan namelijk tal van barrières opwerpen die voorkomen dat de wortels de diepte ingaan. Een bodem kan verdicht raken, te nat zijn of de zuurgraad kan op een bepaalde diepte te hoog zijn.

\section{Invloed graslandgebruik}

Het graslandgebruik heeft invloed op de opbouw en afbraak van wortelreserves en daarmee op de beworteling. Over het algemeen geldt dat hoe vaker en hoe korter wordt ontbladerd, hoe slechter dat is voor de beworteling. In de beweidingsproeven van Amazing Grazing op veen en klei herkennen we die effecten deels. In Zegveld leidt de kortere stoppel en het hogere beweidingsritme bij kurzrasen in de loop van de tijd tot een geringere worteldichtheid dan bij stripgrazen. Op Dairy Campus wordt bij roterend standweiden vaker, maar minder diep, beweid dan bij stripgrazen. Het ontbreken van consistente effecten komt mogelijk doordat het negatieve effect van het hogere beweidingsritme wordt gecompenseerd door het positieve effect van hogere stoppelhoogte.

\section{Bodem}

- Draagkracht

- Verdichting

Zodedichtheid

- Beworteling

- Betreding 


\section{Betreding}

Grazende koeien zetten met gemak 2000 stappen per uur weidegang. Met elke stap drukt $600 \mathrm{~kg}$ koe via haar hoeven de bodem een beetje in elkaar. Wat betekent dat voor bodemverdichting en vertrapping?

\section{Hoefdruk}

De hoefdruk van stilstaande koeien loopt grofweg uiteen van 150 tot $300 \mathrm{kPa}(1,5$ tot 3,0 bar), afhankelijk van het diergewicht en de oppervlakte van de hoef. Metingen in een lers vergelijkend onderzoek tussen $\mathrm{HF}$ en Jersey koeien laten geen verschil zien in de statische hoefdruk, omdat gewicht en hoefoppervlakte nauw verbonden zijn. Als een koe loopt, neemt de bodemdruk tijdelijk toe, tot wel twee keer zoveel. De totale betreding hangt uiteraard af van de veebezetting en de verblijftijd in de wei, of meer specifiek, van het aantal stappen. De verdeling van de betreding over de wei is bovendien zeer wisselend. Perceels- ingangen, drinkplekken en schuilplekken krijgen een bovengemiddeld aantal stappen te verwerken. In de beweidingsproeven van Amazing Grazing zetten de koeien gemiddeld bijna 20.000 stappen per weidedag. Op Zegveld, en vooral bij kurzrasen, was het aantal stappen hoger dan op Dairy Campus. Jersey koeien stapten gemiddeld $33 \%$ meer dan HF koeien.

\section{Ondiepe verdichting}

Het effect van betreding op bodemverdichting en vertrapping is vooral afhankelijk van de grondsoort en het bodemvochtgehalte. Bodemverdichting neemt toe naarmate de grond natter is. De poriën worden in elkaar gedrukt waarbij vooral het aantal en de omvang van de macroporiën afneemt. Als de grond erg nat is, en bijna alle poriën met water verzadigd zijn, neemt de kans op verdichting weer wat af omdat water moeilijker wordt weggedrukt dan
Lees verder

Bodem

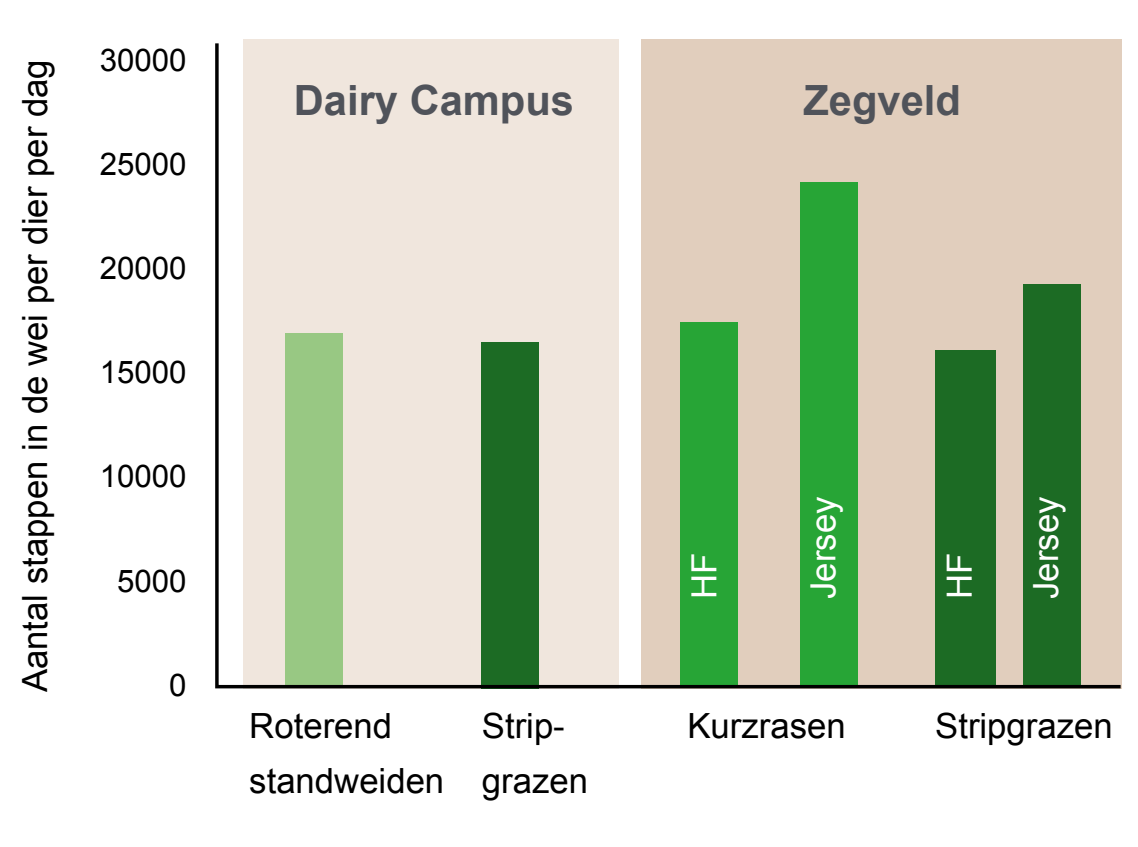

Betreding in de beweidingsproeven van Amazing Grazing op Dairy Campus (bijna 8 uur dagweiden) en Zegveld (ruim 12 uur nachtweiden); gemiddeld aantal stappen, van alle vier de poten, in de wei per dier per dag bij stripgrazen, roterend standweiden en kurzrasen, van HF en Jersey koeien (2016 en 2017)

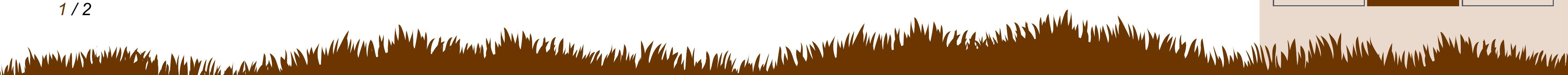

- Draagkracht

- Verdichting

Zodedichtheid

- Beworteling

- Betreding

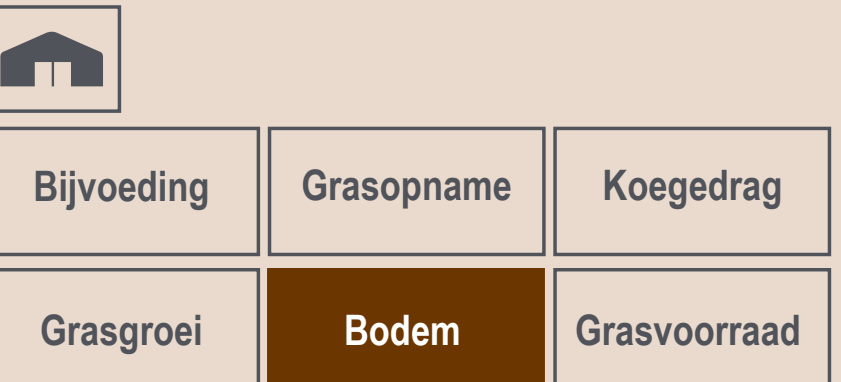


lucht. De gevoeligheid voor verdichting neemt af naarmate een grond meer klei of organische stof bevat.

De hoeven van weidende koeien oefenen meestal meer druk uit op de bodem dan een goed afgestelde band. Op Nederlandse proefvelden in de jaren 1990 was de dichtheid, in de bovenste 5 tot $10 \mathrm{~cm}$, onder beweide veldjes 3 tot $19 \%$ hoger dan die onder veldjes die met relatief lichte proefveldmachines werden gemaaid. Op zand was het effect groter maar wel beperkter in diepte dan op klei.

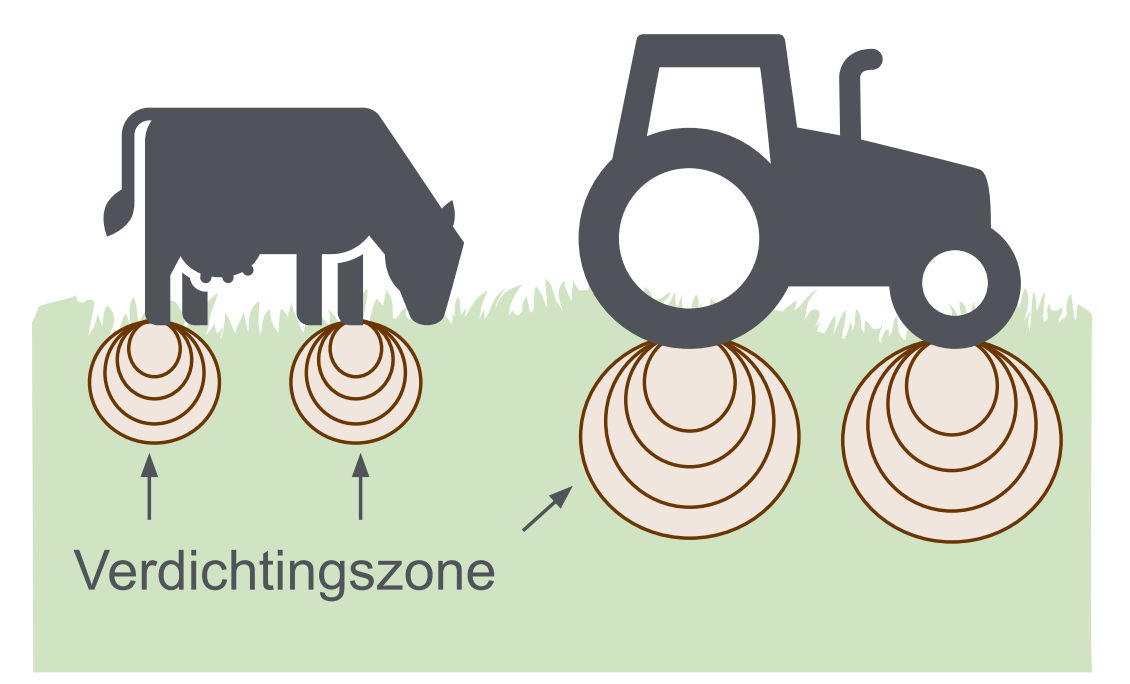

Beweiden leidt tot ondiepere verdichting dan berijden
Recent Oostenrijks onderzoek op praktijkpercelen laat zien dat de verdichting onder percelen toeneemt naarmate het aandeel beweiding hoger is. Een belangrijk verschil is dat de verdichting onder beweiding vooral tot een diepte van $15 \mathrm{~cm}$ optreedt, terwijl onder maaien de verdichting tot $25 \mathrm{~cm}$ reikt. De kleinere oppervlakte van een hoef, in vergelijking met een band, zorgt ervoor dat de verdichting minder diep doorwerkt.

\section{Vertrapping}

In de jaren 1980 is vertrapping vrij willekeurig gedefinieerd als een depressie in de zode van minimaal $4 \mathrm{~cm}$, alhoewel in de praktijk ondiepere vervormingen van de bodem ook wel tot vertrapping worden gerekend. Net als bij verdichting is de mate van vertrapping vooral afhankelijk van grondsoort, bodemvochtgehalte en de stevigheid van de zode. Vertrapping treedt echter pas op onder bijna vochtverzadigde omstandigheden, waarbij de bodem als het ware versmeert rondom de hoef.

\section{Herstel}

Natuurlijke bodemprocessen kunnen in de loop van de tijd bijdragen aan het herstel van de bodem, vooral in de bovenste laag. Wortelgroei en activiteiten van bodemleven zorgen voor een herstel van de structuur. Krimp en zwel kunnen op gronden met meer dan 17,5\% klei ook bijdragen aan het natuurlijk herstel. Veengronden zijn van nature elastischer en veerkrachtiger waardoor ze sneller kunnen herstellen.

\section{Schade voorkomen}

Bodemverdichting en vertrapping zijn onlosmakelijk verbonden met beweiding, maar door slim te weiden kun je het binnen de perken houden. Probeer rekening te houden met de vochttoestand van de bodem. Loop zelf door het perceel en doe de hakkenproef; als je zelf kunt vertrappen, doen de koeien dat ook. Denk bij de inrichting van percelen aan meerdere in- en uitgangen.

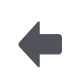

Bodem

- Draagkracht

- Verdichting

Zodedichtheid

- Beworteling

Betreding

\begin{tabular}{|c|c|c|}
\hline Bijvoeding & Grasopname & Koegedrag \\
\hline Grasgroei & Bodem & Grasvoorraac \\
\hline
\end{tabular}




\section{Colofon}

\section{Auteurs}

René Schils ${ }^{1}$, Ingrid van Dixhoorn ${ }^{1}$, Nick van Eekeren ${ }^{2}$, Nyncke Hoekstra ${ }^{2}$, Gertjan Holshof ${ }^{1}$, Idse Hoving ${ }^{1}$, Cindy Klootwijk ${ }^{1}$, Bert Philipsen ${ }^{1}$, Kees van Reenen ${ }^{1}$, Leon Şebek $^{1}$, Marcia Stienezen ${ }^{1}$, Marry van den Top ${ }^{1}$, Joop van der Werf', Ronald Zom'

1 = Wageningen University \& Research

2 = Louis Bolk Instituut

\section{Vormgever}

Topontwerper

\section{Eindredactie}

Communication Services

\section{Beeld}

Shutterstock, Wageningen University \& Research, PixaBay, KTC De Marke, Louis Bolk Instituut, Kutchera (1982), Avinoam Danin (www.flora.org.il), Eddy Teenstra, Valentine \& Matthew (1999)

\section{Copyright en aansprakelijkheid}

Niets uit deze uitgave mag worden verveelvoudigd en/of openbaar worden gemaakt door middel van druk, fotokopie of op welke andere wijze dan ook, zonder voorafgaande schriftelijke toestemming van de uitgever. Auteurs hebben de inhoud van deze uitgave met grote zorgvuldigheid en naar beste weten samengesteld naar de situatie zoals bekend in 2019. Uitgever en redactie aanvaarden evenwel geen aansprakelijkheid voor schade, van welke aard dan ook, die het gevolg is van handelingen en/of beslissingen die gebaseerd zijn op bedoelde informatie.

DOI: https://doi.org/10.18174/475891
Bouwstenen \& animatie

Colofon Bronnenlijst

$$
\text { Lees verder }
$$

\begin{tabular}{|c|c|c|}
\hline Bijvoeding & Grasopname & Koegedrag \\
\hline \hline Grasgroei & Bodem & Grasvoorraad \\
\hline
\end{tabular}




\section{Colofon}

\section{Financiers}

De opzet van Bouwstenen Beweiding is tot stand gekomen in opdracht van het ministerie van Landbouw, Natuur en Voedselveiligheid in het kader van een KennisOnline Kennis op Maat project.

De inhoud komt voort uit het project Amazing Grazing. De opdrachtgever van dit project is de Duurzame Zuivelketen (een gezamenlijk initiatief van LTO Nederland en NZO), met als financiers ZuiveINL en ministerie van Landbouw, Natuur en Voedselveiligheid.

Het project wordt uitgevoerd in samenwerking met RUG/Campus Fryslân, PPS Precisielandbouw 2.0, PPS Ruwvoerproductie en Bodemmanagement, Feed4Foodure en Systeeminnovatie Veenweiden Beweiden. De uitvoerders zijn werkzaam bij Wageningen Livestock Research, Louis Bolk Instituut, Dairy Campus, KTC Zegveld en Wageningen University Leerstoelgroep Dierlijke Productiesystemen.

$2 / 2$
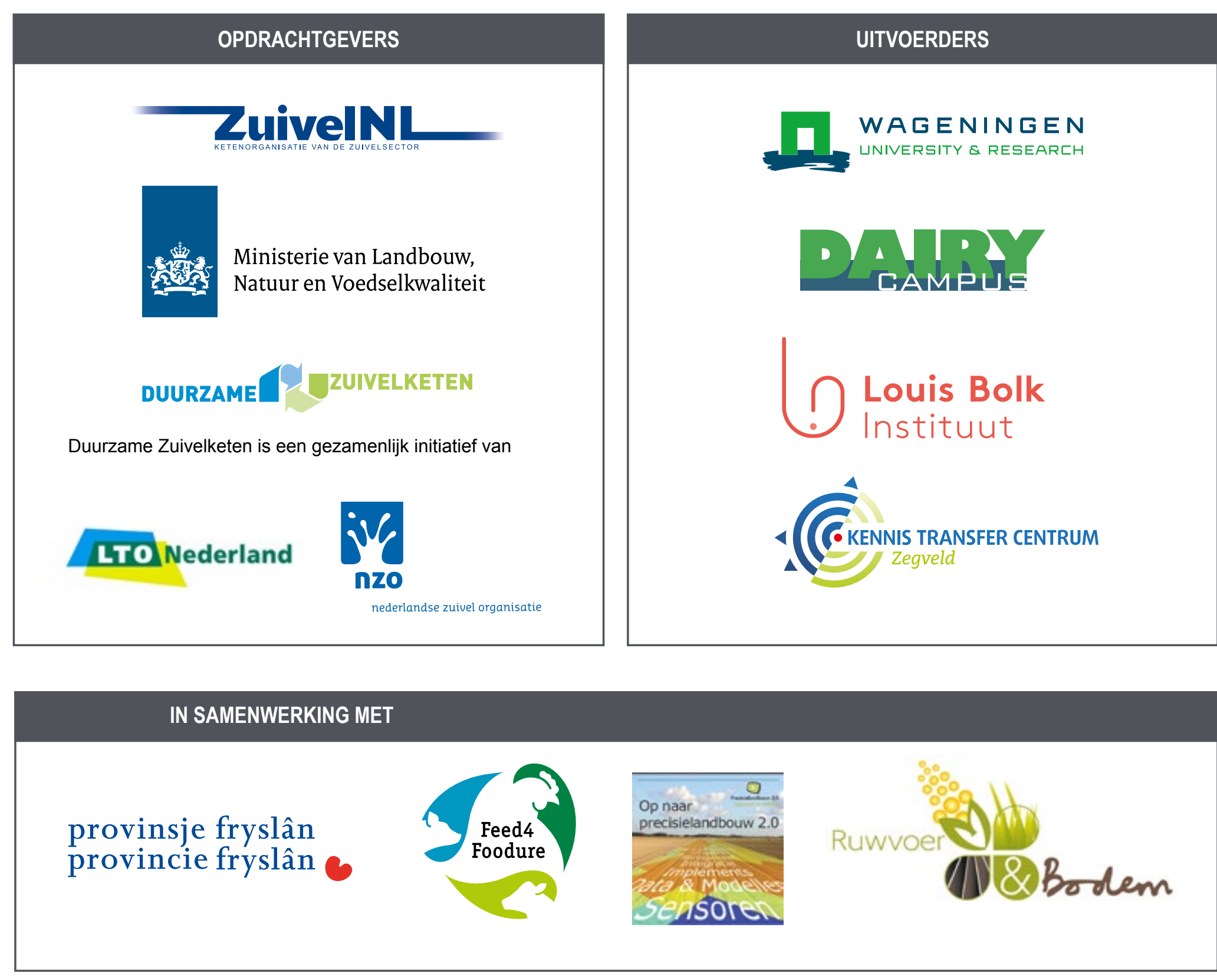

Leeswijzer

들 Bouwstenen \& animatie

8 Colofon

- Bronnenlijst

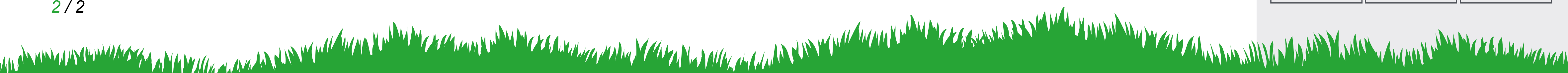




\section{Bronnenlijst}

\section{Bronnen Grasopname}

- Gibb, M., 2007. Grassland management with

emphasis on grazing behaviour. Frontis, 141-157.

- Gregorini, P., Beukes, P. C., Romera, A. J., Levy, G., \& Hanigan, M. D. (2013). A model of diurnal grazing patterns and herbage intake of a dairy cow, MINDY: model description. Ecological Modelling, 270, 11-29.

- Mayes, R.W., Lamb, C.S., Colgrove, P.M., 1986. The Use of Dosed and Herbage N-Alkanes as Markers for the Determination of Herbage Intake. Journal of Agricultural Science 107, 161-170.

- Smit, H. J.; Taweel, H. Z., Tas, B. M.; Tamminga, S.; Elgersma, A., 2005. Comparison of techniques for estimating herbage intake by grazing dairy cows. Journal of Dairy Science, 88, (5), 1827-1836.

\section{Bronnen Grasvoorraad}

- Anonymous,2009. Grazing Notebook, Teagasc and The Irish Farmers Journal, Moorepark, Fermoy, IE, 56 pp.

- Anonymous, 2016. Grashoogtemeterkaart. edepot.wur.nl/369664

- Holshof, G. en M.W.J. Stienezen, 2016. Grasgroe meten met de grashoogtemeter. Wageningen UR (University \& Research) Livestock Research,

Livestock Research Report 925.

edepot.wur.nl/371231
- Romera, A.J., et al, 2010. Use of a pasture growth model to estimate herbage mass at a paddock scale and assist management on dairy farms, Computers and Electronics in Agriculture, Volume 74, Issue 1 Pages 66-72.

- Stienezen M.W.J. en G. Holshof, 2016. Presentatie Gras, groei en grip; de grashoogtemeter geeft zicht. edepot.wur.nl/374974

- Stienezen M.W.J. et al, 2016. E-book Management by Measurement. edepot.wur.nl/376529

- Stienezen, M.W.J., et al, 2018. Feedwedge; de tool voor omweiden. Werkschrift met theorie, praktische toepassing, invulformulieren en voorbeelden; Wageningen Livestock Research, Report 1118. edepot. wur.nl/457132

- Verwer, C., Van Schooten, H., Philipsen, B., Lennsinck, F., Van Houwelingen, K., \& Van Eekeren, N., 2016. Rejection of grass around dung pats; influence of smell, taste or both? In: The multiple roles of grassland in the European bioeconomy. Proceedings of the 26th General Meeting of the European Grassland Federation, Trondheim, Norway, 4-8 September 2016 (p. 430-432). NIBIO. www.cabdirect.org/cabdirect/abstract/2017303837

\section{Bronnen Bodem}

- de Boer, H. C., Deru, J., \& van Eekeren, N. J. M., 2016. Woelen van blijvend grasland op een zandgrond: effecten op bodemstructuur, beworteling en grasopbrengst. Wageningen UR, Livestock Research. library.wur.nl/WebQuery/ wurpubs/fulltext/379564

- Deru, J., Eekeren, N. V., \& Boer, H. D., 2010. Beworteling van grasland-een literatuurstudie: Nutriëntenopname in relatie tot bewortelingsdiepte en-intensiteit; factoren en potentiële maatregelen die de beworteling beïnvloeden.

- van Eekeren, N. J. M., Philipsen, A. P., Lenssinck, F. A. J., \& Meerkerk, B., 2013. Zoeken naar bodemstructuur en draagkracht onder grasland. V-focus december 2013, 32-33. www. louisbolk.org/downloads/2812.pdf

- Greenwood, K. L., \& McKenzie, B. M.,et al, 2001. Grazing effects on soil physical properties and the consequences for pastures: a review. Australian Journal of Experimental Agriculture 41, 1231-1250. - Kutschera, L., Lichtenegger, E., \& Sobotik, M., 1982 Root atlas of central European grassland plants. Volume I. Monocotyledoneae. Gustav Fischer Verlag, Stuttgart. 


\section{Bronnenlijst}

\section{Bronnen Koegedrag}

- GGibbons, J. M., Lawrence, A. B., \& Haskell, M. J., 2010. Measuring sociability in dairy cows. Applied Animal Behaviour Science, 122(2-4), 84-91.

\section{Bronnen Grasgroei}

- Hopkins, A, 2000. Grass, its Production and Utilization (Third Edition). Edited by Oxford: Published for the British Grassland Society by Blackwell Science, pp. 456.

- Starz, W., Steinwidder, A., Pfister, R., \& Rohrer, H. (2013). Etablierung von Wiesenrispengras in einer 3-schnittigen Dauerwiese mittels Kurzrasenweide. http://orgprints.org/21326/1/21326_starz.pdf

\section{Bronnen Bijvoeding}

- Philipsen \& Van den Pol-van Dasselaar, Veevoeding en beweiding, 2017. Powerpoint nr. 7 uit de Basiskennisbundel van dossier Beweiding op GroenKennisnet

\section{Bronnen Algemeen}

- Dossier Beweiding op de website van Groen

Kennisnet

- Klootwijk, C. (2019). Keys to sustainable grazing: economic and environmental consequences of grazing strategies for dairy farms (Doctoral dissertation, Wageningen: Wageningen University).
든 Bouwstenen \& animatie

8 Colofon

\begin{tabular}{|c|c|c|}
\hline \multicolumn{2}{|c|}{} \\
\hline \multicolumn{2}{|c|}{} \\
\hline Bijvoeding & Grasopname & Koegedrag \\
\hline \hline Grasgroei & Bodem & Grasvoorraad \\
\hline
\end{tabular}

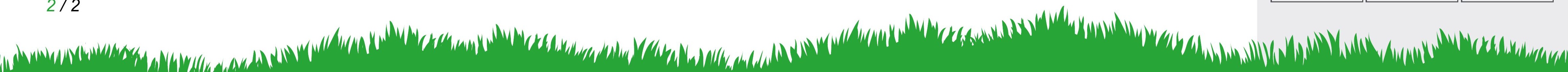

